\title{
A Regio- and Stereodivergent \\ Route to All Isomers of \\ vic-Amino Alcohols
}

\author{
Berit Olofsson
}

Doctoral thesis

Stockholm, 2002

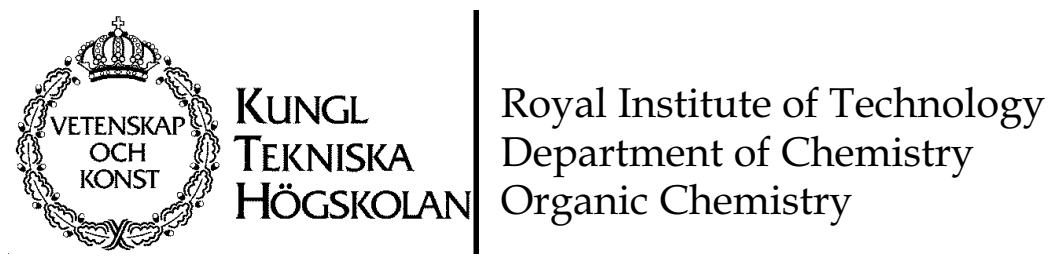

Akademisk avhandling som med tillstånd av Kungl Tekniska Högskolan i Stockholm framlägges till offentlig granskning för avläggande av teknologie doktorsexamen i kemi fredagen den 25:e oktober kl 13.00 i Kollegiesalen, KTH, Valhallavägen 79, Stockholm. Avhandlingen försvaras på engelska. Opponent är Prof. K. J. Hale, University College London. 
ISBN 91-7283-353-X

ISRN KTH/IOK/FR--02/72--SE

ISSN 1100-7974

TRITA-IOK

Forskningsrapport 2002:72

(C) Berit Olofsson, 2002

Ekonomi-Print AB, Stockholm 


\begin{abstract}
The first part of this thesis describes a synthetic strategy that provides all eight possible isomers of a given vic-amino alcohol starting from vinylepoxides. The value of a general route is evident, as several isomers are needed in investigations of structure-activity relationships for pharmacologically active derivatives, and for optimizing the performance of chiral ligands containing the amino alcohol moiety.

Vinylepoxides, obtained in high enantiomeric excess, were ring-opened both with inversion and retention of stereochemistry, delivering two diastereomeric amino alcohols with high regio- and stereoselectivity. Via ring-closure to aziridines and subsequent regioselective ring-opening with suitable oxygen nucleophiles, the two remaining amino alcohols were selectively achieved.

Within this study, two efficient protocols for the regioselective and stereospecific aminolysis of vinylepoxides have been presented. Compared to previous methods, these procedures use milder reaction conditions, shorter reaction times, generally give higher yields and are applicable to a larger set of substrates. Furthermore, the ring-closure of vic-amino alcohols to the corresponding $\mathrm{N}-\mathrm{H}$ vinylaziridines has been investigated. Three routes have been found useful, which one is preferred depends on substrate and scale.

In the second part of the thesis, the synthetic strategy is applied on the synthesis of Sphingosine and its regio- and stereoisomers. Moreover, a rapid way of determining relative configuration of vic-amino alcohols is described, which should be of substantial use when amino alcohols are formed by diastereoselective reactions.
\end{abstract}

Berit Olofsson; A Regio- and Stereodivergent Route to All Isomers of vicAmino Alcohols. Department of Chemistry, Organic Chemistry, Royal Institute of Technology, S-100 44 Stockholm, Sweden.

Keywords: amino alcohols, vinylepoxides, vinylaziridines, oxazolines, oxazolidinones, ring-opening, regioselective, diastereoselective, sphingosine, configuration, NMR spectroscopy. 


\section{Table of contents}

Abstract

Abbreviations

List of publications

Chapter 1 Introduction 1

1.1 Vicinal amino alcohols $\quad 2$

1.2 Synthesis of amino alcohols 3

1.3 Aim of the study 8

1.4 Synthetic strategy 8

Chapter 2 Synthesis of Vinylepoxides $1^{\text {IV }} \quad 11$

2.1 Introduction 11

2.2 Synthesis of vinylepoxides 1

Chapter 3 Aminolysis of Vinylepoxides 1 to anti-Amino Alcohols $2^{\text {I-IV }} \quad 17$

$\begin{array}{ll}3.1 & \text { Conventional Aminolysis } \\ 3.2 & 17\end{array}$

3.2 Microwave-assisted aminolysis 18

3.3 Large Scale Aminolysis 19

Chapter $4 \quad \operatorname{Pd}(0)$-catalyzed Epoxide Opening leading to syn-Amino Alcohols $3^{\text {II-IV }} \quad 23$

4.1 $\operatorname{Pd}(0)$-catalyzed Ring-Opening of $\mathbf{1} 23$

4.2 Detosylation and Hydrolysis 25

Chapter 5 Ring-closure of anti-Amino Alcohols 2 to

Vinylaziridines $4^{\text {II-V }} \quad 27$

$5.1 \quad$ Background to aziridines 27

5.2 Investigation of ring-closure strategies 28

$5.3 \quad$ Synthesis of vinylaziridines $\mathbf{4 b - f} \quad 32$

Chapter 6 Solvolysis of Vinylaziridines 4 to

anti-Amino Alcohols 5 II-IV $\quad 35$

6.1 Introduction 35

6.2 Solvolysis of vinylaziridines 4

Chapter 7 Aziridine Rearrangement leading to syn-Amino Alcohols $6^{\text {II-IV }} \quad 39$

$\begin{array}{lll}7.1 & \text { Acetylation } & 40\end{array}$

7.2 Rearrangement 40

7.3 Hydrolysis $\quad 42$ 
Chapter 8 Synthesis of Sphingosine and its Regio- and Stereoisomers $^{\text {VI }} \quad 45$

8.1 Background 45

8.2 Synthesis of vinylepoxide 1l 46

8.3 Ring-openings of vinylepoxide $11 \quad 49$

8.4 Synthesis and ring-openings of vinylaziridine $4 \mathbf{5} \quad 50$

Chapter 9 Determination of Regiochemistry and Relative Stereochemistry of vic-Amino Alcohols ${ }^{\text {IV, VII }} \mathbf{5 3}$

9.1 Introduction 53

$\begin{array}{ll}9.2 & \text { Synthesis of Oxazolidinones }\end{array}$

9.3 NMR determination 56

Concluding remarks $\quad 59$

$\begin{array}{lr}\text { Acknowledgments } & 60\end{array}$

$\begin{array}{lr}\text { Appendices } & 61\end{array}$

Papers I -VII 


\section{Abbreviations}

$\begin{array}{ll}\Delta & \text { heat } \\ \text { BINOL } & \text { 1,1-bi-2-naphtol } \\ \text { Boc } & \text { t-butoxy carbonyl } \\ \text { Cbz } & \text { benzyloxycarbonyl } \\ \text { dba } & \text { dibenzylideneacetone } \\ \text { DEAD } & \text { diethyl azodicarboxylate } \\ \text { DET } & \text { diethyl tartrate } \\ \text { (DHQ) }{ }_{2} \text { PHAL } & \text { hydroquinine 1,4-phtalazinediyl diether } \\ \text { DIAD } & \text { diisopropyl azodicarboxylate } \\ \text { DIBALH } & \text { diisobutylaluminum hydride } \\ \text { DMAP } & \text { 4-dimethylaminopyridine } \\ d r & \text { diastereomeric ratio } \\ d s & \text { diastereoselectivity } \\ e s & \text { enantioselectivity } \\ \text { HRMS } & \text { high resolution mass spectroscopy } \\ \text { IBX } & \text { 2-iodoxybenzoic acid } \\ \text { Ipc } & \text { isopinocampheyl } \\ \text { KHMDS } & \text { potassium hexamethyldisilazane } \\ \text { LDA } & \text { litium diisopropylamide } \\ \text { mCPBA } & m \text {-chloroperbenzoic acid } \\ \text { NMI } & \text { 1-methylimidazole } \\ \text { Ms } & \text { methanesulfonyl } \\ \text { NOE } & \text { nuclear Overhauser effect } \\ \text { PMB } & p \text {-methoxybenzyl } \\ \text { SAE } & \text { Sharpless asymmetric epoxidation } \\ \text { TBHP } & t \text {-butyl hydroperoxide } \\ \text { TFA } & \text { trifluoroacetic acid } \\ \text { TMS } & \text { trimethylsilyl } \\ \text { TPAP } & \text { tetrapropylammonium perruthenate } \\ \text { Tr } & \text { trityl = triphenylmethyl } \\ \text { Ts } & p \text {-toluenesulfonyl } \\ v i c & \text { vicinal } \\ & \end{array}$




\section{List of publications}

This thesis is based on the following publications, in the text referred to by their Roman numerals I-VII.

I. Microwave-assisted Aminolysis of Vinylepoxides Berit Olofsson, Ulf M. Lindström and Peter Somfai Tetrahedron Lett. 1999, 40, 9273-9276.

II. A Regio- and Stereodivergent Synthesis of vic-Amino Alcohols Berit Olofsson, Uttam Khamrai and Peter Somfai Org. Lett. 2000, 2, 4087-4089.

III. A Regio- and Stereodivergent Route to All Isomers of vic-Amino Alcohols, Berit Olofsson and Peter Somfai Latvijas J. Chem. 2002, 1, 69-78.

IV. A Regio- and Stereodivergent Route to All Isomers of vic-Amino Alcohols, Berit Olofsson and Peter Somfai J. Org. Chem. in press.

V. Synthesis of $N$-H Vinylaziridines: A Comparative Study Berit Olofsson, Roel Wijtmans and Peter Somfai Tetrahedron 2002, 58, 5979-5982.

VI. Divergent Synthesis of D-erythro-Sphingosine, L-threo-Sphingosine and their Regioisomers

Berit Olofsson and Peter Somfai Manuscript.

VII. Determination of the Relative Configuration of vic-Amino Alcohols Berit Olofsson and Peter Somfai Submitted. 



\section{Introduction}

One of the main objectives of organic chemistry has always been the synthesis of natural products, as they can often be isolated from Nature only in minor amounts. Very complex molecules have been synthesized as early as in the 1950s, albeit in poor total yields. In the last decades chemists have, besides synthesizing extraordinarily complicated compounds, focused on optimizing already present reactions and developing new reactions which could simplify and shorten these syntheses. Great efforts to develop libraries of efficient reactions for each type of transformation have been made, in order to simplify the design of complex molecules. With these libraries at hand, each subunit of a complex molecule can be synthesized by means of well-known techniques, presupposed that the subunits can be combined in a later stage.

Many natural products contain one or more stereogenic centers, which complicate their syntheses substantially. Asymmetric synthesis is one of the most expanding fields in organic chemistry, since the discovery that the two enantiomers of a chiral compound can have different pharmacological effect. This can be exemplified by propranolol, which was introduced in the 1960s for the treatment of heart disease. The (-)-enantiomer is a potent $\beta$-blocker, whereas the (+)-enantiomer acts a contraceptive (Figure 1). ${ }^{1}$

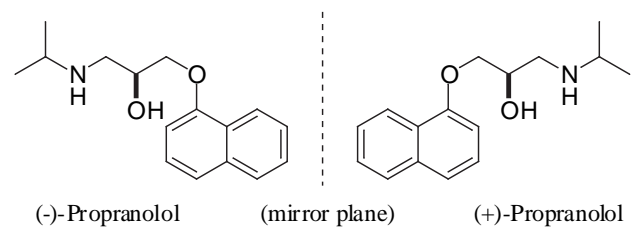

Figure 1: The two enantiomers of propranolol.

Asymmetric reactions are often developed from well-known procedures. Chiral auxiliaries or catalysts bearing chiral ligands can be utilized to afford induction towards one of the possible isomers. As the research on new

${ }^{1}$ Aitken, R. A.; Kilényi, S. N. Asymmetric synthesis; Blackie Academic \& Professional: Glasgow, 1992. 
asymmetric processes is continuously increasing, the need for novel chiral auxiliaries and ligands is extensive. ${ }^{2,3}$

\subsection{Vicinal amino alcohols}

The $\beta$-amino alcohol moiety is found in a wide variety of biologically active alkaloids and peptides. ${ }^{4}$ The subunit is also present in many synthetic, pharmacologically active molecules. Hydroxyamino acids constitute a major group among the naturally occurring amino alcohols. Lipids and lipid-like molecules often contain an amino alcohol moiety, as exemplified by sphingosine (Figure 2). This compound is the major backbone in glycosphingolipids, which are vital in cell recognition events such as growth, differentiation and immune response. Cyclic amino alcohols constitute a third group, where the amino residue is contained within a ring. Representatives of this group are deoxynojirimycin, which is an $\alpha$-glycosidase inhibitor with therapeutic potential due to its low cytotoxicity, and quinine that is used as a drug for the treatment of malaria, high fever and other diseases. ${ }^{4}$<smiles>CC=CC(O)C(N)CO</smiles>

Sphingosine<smiles>OCC1NCC(O)C(O)C1O</smiles>

Deoxynojirimycin

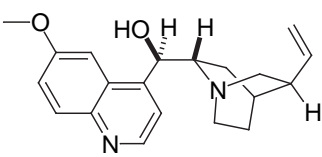

Quinine

Figure 2: Examples of natural products incorporating a vic-amino alcohol moiety.

Peptidomimetics are the most common among synthetic, pharmacologically active compounds containing a vic-amino alcohol subunit. This group of peptide analogues is typified by the HIV protease inhibitor saquinavir (Figure 3). ${ }^{4}$<smiles>CC(C)C(C)C(=O)N[C@@H](CP)C[C@@H](O)[C@H](Cc1ccccc1)NC(=O)OCc1cncs1</smiles><smiles>[R]C1NC(=O)OC1[R]</smiles>

Oxazolidinone<smiles>[R]C1COC(C([R])C2=NC([R])CO2)=N1</smiles>

Bis(oxazoline)

Figure 3: Vic-amino alcohol derivatives used in asymmetric synthesis.

The importance of vicinal amino alcohols is also well recognized in asymmetric synthesis, as many chiral auxiliaries and ligands contain this substructure. Some representative examples of amino alcohol-derived compounds are shown in Figure 3. Evans' oxazolidinones are utilized as chiral auxiliaries in various reactions, e.g. asymmetric alkylations. Bisoxazolines are employed as ligands in enantioselective cyclopropanations and aziridinations. ${ }^{2,3}$

\footnotetext{
${ }^{2}$ Ager, D. J.; Prakash, I.; Schaad, D. R. Chem. Rev. 1996, 96, 835-875.

${ }^{3}$ Seyden-Penne, J. Chiral Auxiliaries and Ligands in Asymmetric Synthesis; Wiley: New York, 1995.

${ }^{4}$ Bergmeier, S. C. Tetrahedron 2000, 56, 2561-2576.
} 


\subsection{Synthesis of amino alcohols}

Existing synthetic routes to enantiopure amino alcohols rely heavily on the derivatization of the available pool of amino acids, inherently limiting the number of accessible derivatives. ${ }^{5}$ The great efforts made to develop asymmetric routes to 1,2-amino alcohols can be divided into two strategically different categories. Amino alcohols formed by concomitant creation of a new C-C bond, i.e. by coupling reactions, constitutes the first class. More commonly, the amino alcohol moiety is constructed without alteration of the carbon skeleton. This category can be further divided into three subclasses, as depicted in Figure $4 .{ }^{4}$

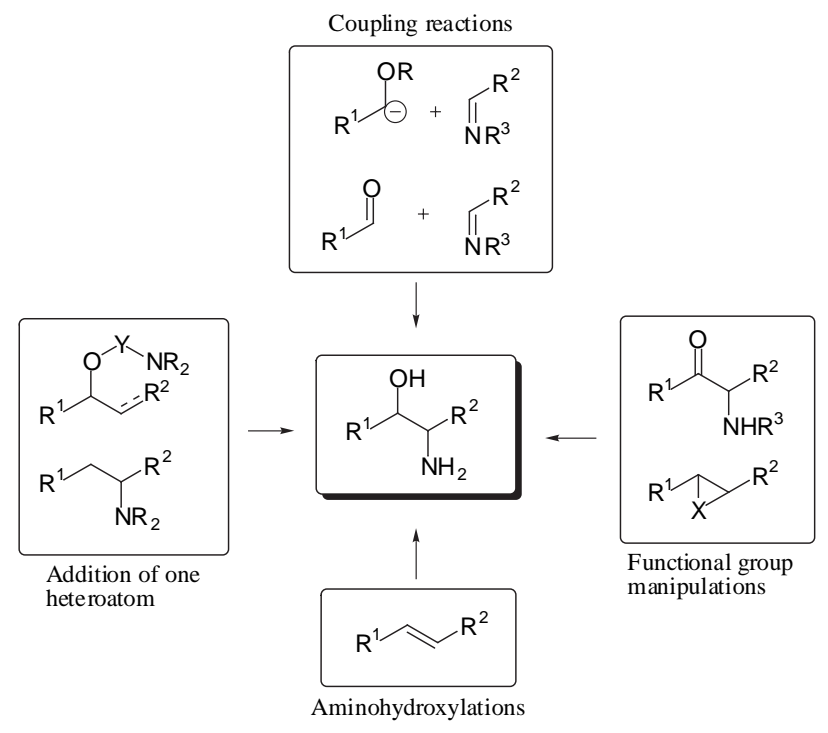

Figure 4: Syntheses of amino alcohols divided into categories.

\subsubsection{Reactions forming C-C bonds}

The most effective synthesis of amino alcohols should be the coupling of two molecules, one containing an oxygen functionality and the other a nitrogen functionality. As two new stereocenters are created simultaneously, both enantioand diastereoselectivity must be controlled. The strategy is generally limited by the structural demands on the substrates, in order to obtain high selectivities.

Stereoselective nucleophilic additions to imines afford amino alcohols with high enantioselectivity. ${ }^{6}$ In the addition of $\alpha$-alkoxyenolates to aldimines, the choice of enolate decides which isomer (syn/anti) will be the major product (Scheme 1). ${ }^{7}$ A recent report by Jørgensen describes a proline-catalyzed $\alpha$ -

${ }^{5}$ Reetz, M. T. Angew. Chem. Int. Ed. Engl. 1991, 30, 1531-1546.

${ }^{6}$ (a) Hattori, K.; Yamamoto, H. Tetrahedron 1994, 50, 2785-2792. (b) Tanaka, Y.; Taniguchi, N.; Uemura, M. Org. Lett. 2002, 4, 835-838.

${ }^{7}$ Kobayashi, S.; Ishitani, H.; Ueno, M. J. Am. Chem. Soc. 1998, 120, 431-432. 
amination of ketones using an azodicarboxylate as the nitrogen source. The resulting $\alpha$-hydrazino ketones, which are formed with good enantioselectivities, can be further derivatized into $s y n$ - or ant $i$-amino alcohols by sequential reduction steps. ${ }^{8}$
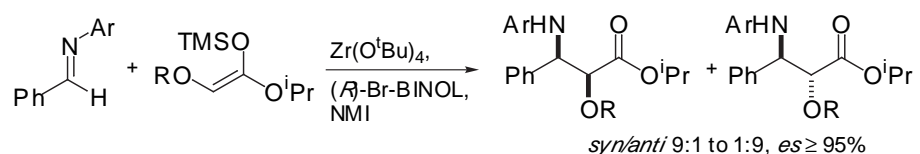

Scheme 1: Nucleophilic addition to an imine.

Additions of allylic imines to aldehydes primarily result in $\gamma$-amino alcohols. To obtain $\alpha$-addition, the imine can be transformed into a 3-aminoallylborane. When chiral boron reagents are used, vinylic 1,2-amino alcohols can be obtained with high enantioselectivities (Scheme 2). ${ }^{9}$

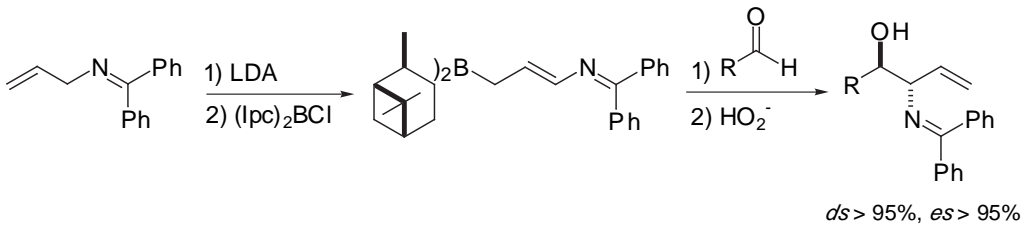

Scheme 2: Aminoallylborane addition to aldehydes.

In a three-component, boronic acid Mannich approach, Petasis recently demonstrated an elegant synthesis of anti-amino alcohols (Scheme 3). ${ }^{10}$ An $\alpha$ hydroxyaldehyde is condensed with an amine to form the corresponding imine, which reacts with the boronic acid derivative to provide the anti-amino alcohol with excellent diastereoselectivity. The reaction works well with secondary amines, but is less efficient with primary amines and ammonium salts. The major limitation is the need for an aryl or olefinic boronic acid derivative. ${ }^{11}$

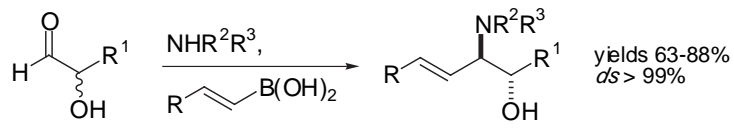

Scheme 3: The boronic acid Mannich reaction.

When one of the two stereocenters is set, the other can be created with good diastereoselectivity. This happens in the addition of organometallic nucleophiles to $\alpha$-aminocarbonyls, derived from chiral amino acids. (Scheme 4 ). ${ }^{5}$ The asymmetric induction obtained in the reaction can be interpreted by means of the Felkin-Anh non-chelation control model. Drawbacks of this method are the

\footnotetext{
${ }^{8}$ Kumaragurubaran, N.; Juhl, K.; Zhuang, W.; Bøgevig, A.; Jørgensen, K. A. J. Am. Chem. Soc. 2002, 124, 6254-6255.

${ }^{9}$ Barrett, A. G. M.; Seefeld, M. A.; White, A. J. P. J. Org. Chem. 1996, 61, 2677-2685.

${ }^{10}$ Petasis, N. A. J. Am. Chem. Soc. 1998, 120, 11798-11799.

${ }^{11}$ For a similar approach, see List, B.; Pojarliev, P.; Biller, W. T.; Martin, H. J. J. Am. Chem. Soc. 2002, 124, 827-833.
} 
stability problems of $\alpha$-aminocarbonyls and the sometimes moderate diastereoselectivities obtained. ${ }^{12}$

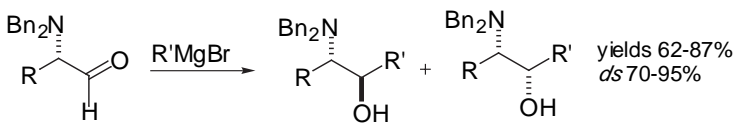

Scheme 4: Nucleophilic addition to $\alpha$-aminocarbonyls.

In this category, the addition of $\alpha$-alkoxyenolates to aldimines is the most flexible reaction, as the choice of enolate decides which isomer (syn/anti) will be the major product (see Scheme 1).

\subsubsection{Reactions not altering the carbon skeleton}

More commonly, the amino alcohol moiety is constructed without alteration of the carbon skeleton. The substrates are primarily alkenes or alkene derivatives, and the reactions often proceed stereospecifically. Regioselectivity is instead a problem, which can be circumvented only when the substrate is substituted by groups having different electronic or steric influences.

\section{Functional group manipulations}

With the advancement of diastereo- and enantioselective syntheses of epoxides, cleavage of oxiranes by nitrogen nucleophiles is nowadays one of the most investigated routes to vicinal amino alcohols. ${ }^{13}$ Both syn- and anti-amino alcohols are available by employing cis- and trans-epoxides, respectively. The strategy is, however, often limited by poor regioselectivity, except with terminal oxiranes. Substituents on the oxirane ring have both steric and electronic influence on the regioselectivity; conjugating substituents, e.g. phenyl and vinyl, usually promote ring opening at the adjacent carbon. ${ }^{14}$ Regioselective azide opening of epoxyalcohols can be achieved by employing $\operatorname{Ti}\left(\mathrm{O}^{\mathrm{i}} \mathrm{Pr}\right)_{2}\left(\mathrm{~N}_{3}\right)_{2}$, which coordinates to the alcohol moiety before nucleophilic attack (Scheme 5). ${ }^{15}$

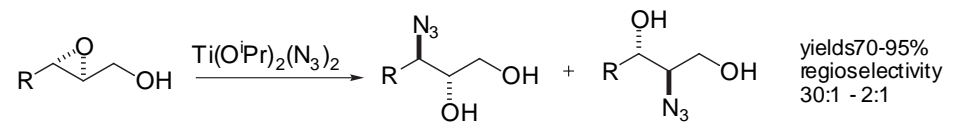

Scheme 5: Nucleophilic ring-opening of epoxides.

Cyclic sulfates ${ }^{16}$ and carbonates, ${ }^{17,18}$ derived via asymmetric dihydroxylation of

\footnotetext{
${ }^{12}$ Veeresha, G.; Datta, A. Tetrahedron Lett. 1997, 38, 5223-5224.

${ }^{13}$ (a) Hayakawa, H.; Okada, N. M., M.; Miyashita, M. Tetrahedron Lett. 1999, 40, 4589-4592. (b) Larrow, J. F.; Schaus, S. E.; Jacobsen, E. N. J. Am. Chem. Soc. 1996, 118, 7420-7421. (c) Zwanenburg, B. Pure Appl. Chem. 1999, 71, 423-430.

${ }^{14}$ Jaime, C.; Ortuno, R., M.; Font, J. J. Org. Chem. 1988, 53, 139-141.

${ }^{15}$ Caron, M.; Carlier, P. R.; Sharpless, K. B. J. Org. Chem. 1988, 53, 5185-5187.

${ }^{16}$ Lohray, B. B.; Gao, Y.; Sharpless, K. B. Tetrahedron Lett. 1989, 30, 2623-2626. ()Lohray, B. B. Synthesis 1992, 1035-1052.

${ }^{17}$ Chang, H.-T.; Sharpless, B. Tetrahedron Lett. 1996, 37, 3219-3222.
} 
the corresponding alkenes, can be ring-opened with nitrogen nucleophiles to give anti-amino alcohols. The opening occurs in the most activated position with overall yields of $70-80 \%$ (Scheme 6). In a similar fashion syn-diols can be transformed into syn-amino alcohols. ${ }^{18}$

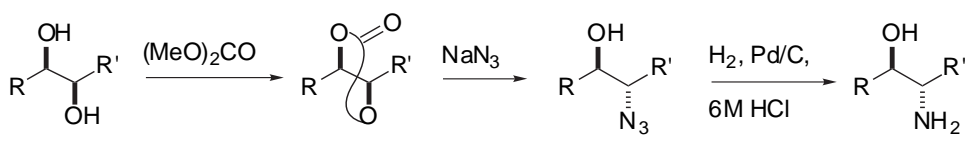

Scheme 6: Nucleophilic opening of cyclic carbonates.

Enantioselective aziridination is known to be more difficult than asymmetric epoxidation, and general methods are missing. Ring-openings of aziridines with oxygen nucleophiles to afford 1,2-amino alcohols are consequently not as common as epoxide openings, yet interesting. Nucleophiles employed to date are water, alcohols and carboxylic acids. ${ }^{19,20}$

Reductions of $\alpha$-amino ketones can be made diastereoselective towards synthesis of either syn- or anti-amino alcohols, depending on the choice of protective group (Scheme 7). ${ }^{21}$ Upon treatment of Cbz-protected substrate with $\mathrm{LiAlH}\left(\mathrm{O}^{\mathrm{t}} \mathrm{Bu}\right)_{3}$, the anti-isomer is formed with excellent diastereoselectivity. When the same substrate is trityl-protected, the syn-isomer is predominantly formed, although sometimes with moderate selectivity. Due to the relative instability of $\alpha$-hydroxyimines, corresponding reductions of these compounds are seldom performed. ${ }^{4}$

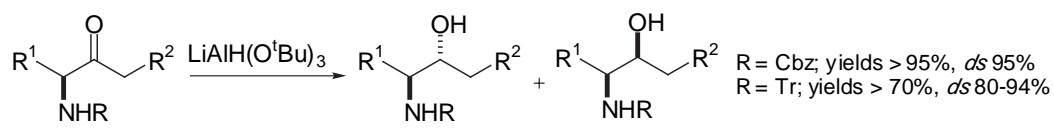

Scheme 7: Diastereoselective reduction.

\section{Aminohydroxylation}

The most straightforward route among the functional group manipulations is evidently the asymmetric aminohydroxylation of alkenes. Sharpless has developed a variant of the well-known dihydroxylation that utilizes the same oxidant and ligand system. $\alpha, \beta$-Unsaturated esters and phosphonates are the best substrates for this reaction, which delivers syn-amino alcohols with high enantioselectivities but often with moderate yields due to poor regioselectivities (Scheme 8). ${ }^{22}$

${ }^{18}$ Cho, G. Y.; Ko, S. Y. J. Org. Chem. 1999, 64, 8745-8747.

19 Takeuchi, H.; Koyama, K. J. Chem. Soc., Perkin Trans. 2 1981, 121-126.

${ }^{20}$ (a) Ibuka, T.; Nakai, K.; Akaji, M.; Tamamura, H.; Fujii, N.; Yamamoto, Y. Tetrahedron 1996, 52, 11739-11752. (b) Cantrill, A. A.; Osborn, H. M. I.; Sweeney, J. Tetrahedron 1998, 54, 2181-2208.

${ }^{21}$ Hoffman, R. V.; Maslouh, N.; Cervantes-Lee, F. J. Org. Chem. 2002, 67, 1045-1056.

22 (a) Li, G.; Chang, H.-T.; Sharpless, B. K. Angew. Chem. Int. Ed. Engl. 1996, 35, 451. (b) O'Brien,

P. Angew. Chem. Int. Ed. Engl. 1999, 38, 326-329. 


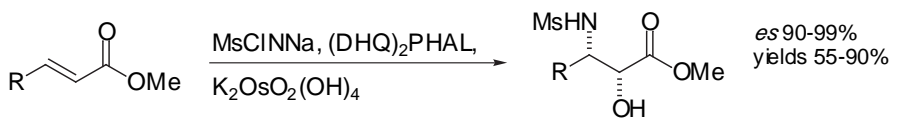

Scheme 8: Sharpless asymmetric aminohydroxylation.

A complimentary two-step procedure is described by Davies (Scheme 9). In this reaction sequence, a chiral amide anion added to an $\alpha, \beta$-unsaturated ester. The resulting enolate was trapped with an oxygen electrophile to yield the antiamino alcohol with excellent diastereoselectivity. ${ }^{23}$

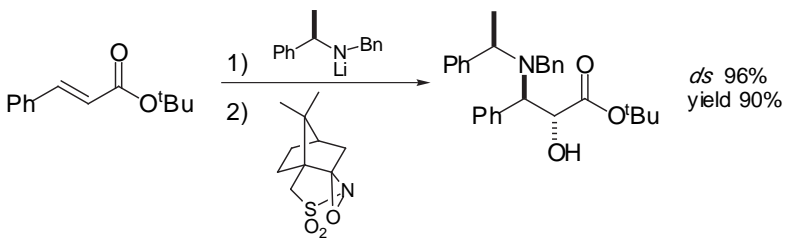

Scheme 9: Two-step aminohydroxylation.

Both of the above methods suffer from very limited substrate tolerance, which can be exemplified by the aminohydroxylation of cyclohexene. The corresponding syn-amino alcohol was obtained in $48 \%$ yield with $66 \%$ enantioselectivity.

\section{Addition of one heteroatom}

This strategy is rarely employed, although some examples exist. Chiral auxiliaries are not utilized in these reactions; instead the resident heteroatom directs the nucleophile. The intramolecular addition of an acyloxynitrene to an olefin is an indirect synthetic route to amino alcohols via oxazolidinones (Scheme 10). ${ }^{24}$ The reaction sequence starts by formation of an azidoformate from the corresponding allylic alcohol. Thermolysis of this species provides a bicyclic aziridine, which can be ring-opened to the corresponding oxazolidinone.

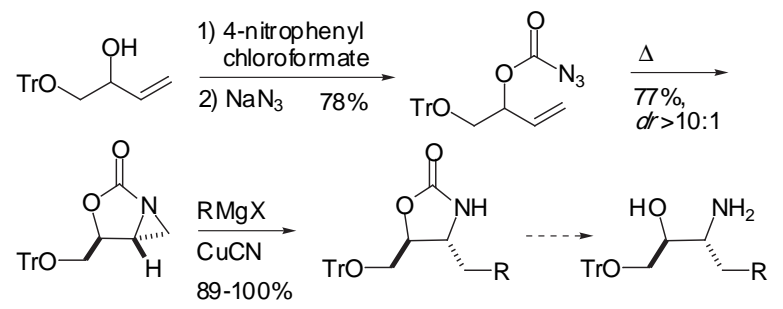

Scheme 10: Intramolecular addition of an acyloxynitrene to an olefin.

The corresponding additions of oxygen nucleophiles to nitrogen-containing molecules are seldom attempted. In the oxa-Michael addition of $\mathrm{N}$ formylnorephedrine to nitroalkenes, anti-amino alcohols are formed with

\footnotetext{
${ }^{23}$ Bunnage, M. E.; Chernega, A. N.; Davies, S. G.; Goodwin, C. J. J. Chem. Soc., Perkin Trans. 1 1994, 2373-2384.

${ }^{24}$ Bergmeier, S. C.; Stanchina, D. M. J. Org. Chem. 1997, 62, 4449-4456.
} 
excellent selectivities in a four step sequence (Scheme 11). ${ }^{25}$<smiles>[R]C(=O)N[13C](=O)[O-]</smiles>

Scheme 11: Oxa-Michael addition to nitroalkenes.

\subsection{Aim of the study}

Despite the great interest in the field of vic-amino alcohols, a divergent route from a common starting material towards all possible regio- and stereoisomers of a vicinal amino alcohol is still missing. ${ }^{2,4}$ The synthetic planning is thus substantially complicated by the requirement of a separate synthetic route for each isomer. A divergent route leading to all possible isomers would be a great simplification for studies on structure-activity relationships of pharmacologically active derivatives incorporating the amino alcohol moiety. A divergent route would also allow optimization of the performance of chiral ligands containing this structural motif.

We therefore set out to develop a route leading to all eight possible isomers of a given vic-amino alcohol, starting from a common substrate that could be readily synthesized. To demonstrate the value of this route, it would then be applied to natural product synthesis.

\subsection{Synthetic strategy}

The requirements of a generally applicable synthetic route are readily available starting materials, flexibility, predictability and high regio- and diastereoselectivity. These demands can be met by choosing vinylepoxides as substrates, as they are known to be ring-opened selectively at the allylic position by hard nucleophiles. ${ }^{14}$ Furthermore, both enantiomers are readily available in high enantiomeric excess via asymmetric epoxidation strategies.

As depicted in Scheme 12, the synthetic strategy designed to fulfill these specifications starts by ring-opening of epoxides 1 with a nitrogen nucleophile. Selective ring-opening at the allylic position can be performed either with inversion or retention of stereochemistry, yielding anti- and syn-amino alcohols $\mathbf{2}$ and 3, respectively. Amino alcohols $\mathbf{2}$ can subsequently be ring-closed to the corresponding vinylaziridines $\mathbf{4}$. These species can be selectively ring-opened at the allylic position with an oxygen nucleophile, either with inversion or retention, to furnish anti-and syn-amino alcohols 5 and $\mathbf{6}$. The remaining set of

${ }^{25}$ Berner, O. M.; Tedeschi, L.; Enders, D. Eur. J. Org. Chem. 2002, 1877-1894. 
enantiomeric amino alcohol isomers can easily be obtained by starting from the enantiomeric vinylepoxides ent-1.

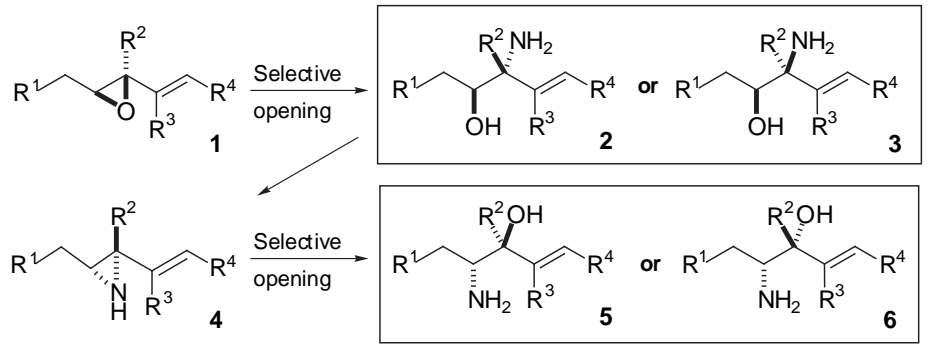

Scheme 12. Synthetic strategy. 


\section{Synthesis of Vinylepoxides 1}

(Paper IV)

\subsection{Introduction}

Epoxides are often used as intermediates in asymmetric synthesis, due both to reliable asymmetric epoxidation methods and to facile ring-opening reactions allowing straightforward elaboration to new functionalities. ${ }^{26}$ The development of Sharpless asymmetric epoxidation of allylic alcohols in 1980 constitutes a breakthrough in asymmetric synthesis, and to date this method remains the most applied asymmetric epoxidation protocol (Scheme 13). ${ }^{27}$ A wide range of substrates can be used in the reaction; $(E)$-allylic alcohols generally give high enantioselectivity, whereas the reaction is more substrate dependent with $(Z)$ allylic alcohols. Conjugated dienols are often problematic substrates due to reduced reactivity. Moreover the products can undergo a Payne rearrangement, which makes them susceptible towards further epoxidation. ${ }^{28,29}$ With all reagents commercially available, the main drawback of the SAE-reaction is the substrate limitation to allylic alcohols.

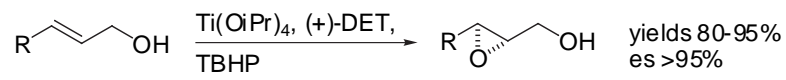

Scheme 13. Sharpless asymmetric epoxidation.

Ten years after Sharpless' discovery, Jacobsen reported an asymmetric

${ }^{26}$ (a) George, T.; Mabon, R.; Sweeney, G.; Sweeney, J. B.; Tavassoli, A. Journal of the Chemical Society-Perkin Transactions 1 2000, 2529-2574. (b) Bonini, C.; Righi, G. Tetrahedron 2002, 58, 4981-5021.

${ }^{27}$ (a) Katsuki, T.; Martin, V. S. In Orgainc Reactions; Paquette, L. A., Ed.; John Wiley \& Sons, Inc.: 1996; Vol. 48, p 1-285. (b) Gao, Y.; Hanson, R. M.; Klunder, J. M.; Ko, S. Y.; Masamune, H.; Sharpless, K. B. J. Am. Chem. Soc. 1987, 109, 5765-5780.

${ }^{28}$ Werschofen, S.; Scharf, H.-D. Synthesis 1988, 854-858.

${ }^{29}$ Bernet, B.; Vasella, A. Tetrahedron Lett. 1983, 24, 5491-5494. 
epoxidation of unfunctionalized olefins using chiral Mn-salen catalysts (Scheme 14).$^{30}$ This reaction works best on $(Z)$-disubstituted alkenes, although several triand tetra-substituted olefins have been successfully epoxidized. ${ }^{31}$ The reaction often requires ligand optimization in order to reach high enantioselectivity.

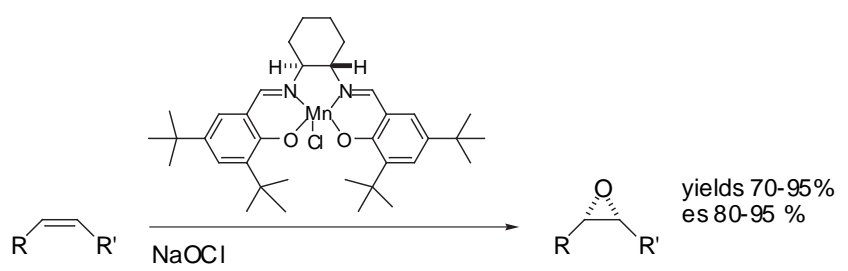

Scheme 14. Jacobsen's asymmetric epoxidation.

Chiral dioxiranes have recently been reported to catalyze epoxidations. The best results have been obtained by Shi, who has developed ketone 7 as catalyst precursor (Scheme 15). ${ }^{32,33}$ Although the first results were obtained with $(E)$ alkenes, Shi has now developed reaction conditions suitable for nearly all types of substrates, including (Z)-alkenes and terminal olefins. ${ }^{34}$ Furthermore, a monoepoxidation of dienes has been reported, where the most electron rich double bond is epoxidized in good selectivity. ${ }^{35}$ As this catalyst is rather new, few applications have been published and its potential remains unrevealed.

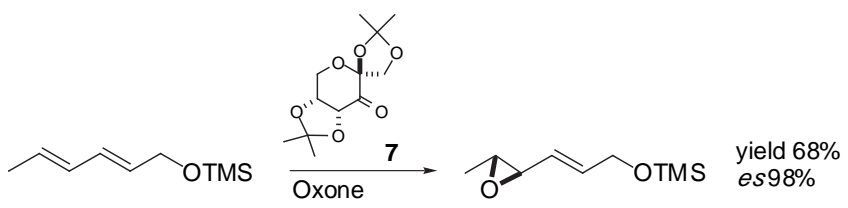

Scheme 15. Shi's asymmetric monoepoxidation of dienes.

Indirect routes to enantiopure epoxides have also proven valuable in certain cases, i.e. asymmetric dihydroxylation with sequential ring-closure. ${ }^{36}$ Aggarwal has recently developed an asymmetric epoxide formation from sulfur ylides and aldehydes. $^{37}$

\footnotetext{
${ }^{30}$ Zhang, W.; Loebach, J. L.; Wilson, S. R.; Jacobsen, E. N. J. Am. Chem. Soc. 1990, 112, 28012803.

${ }^{31}$ Brandes, B. D.; Jacobsen, E. N. J. Org. Chem. 1994, 59, 4378-4380.

${ }^{32}$ Wang, Z.-X.; Tu, Y.; Frohn, M.; Zhang, J.-R.; Shi, Y. J. Am. Chem. Soc. 1997, 119, 11224-11235.

${ }^{33}$ This ketone is oxidized to the corresponding dioxirane in the catalytic cycle. 7 is commercially available, ent-7 can be prepared in five steps from L-sorbose.

${ }^{34}$ (a) Frohn, M.; Shi, Y. Synthesis 2000, 1979-2000. (b) Tian, H.; She, X.; Yu, H.; Shu, L.; Shi, Y. J. Org. Chem. 2002, 67, 2435-2446. (c) Wu, X.-Y.; She, X.; Shi, Y. J. Am. Chem. Soc. 2002, 124, 8792-8793.

${ }^{35}$ Frohn, M.; Dalkiewicz, M.; Tu, Y.; Wang, Z.-X.; Shi, Y. J. Org. Chem. 1998, 63, 2948-2953.

${ }^{36}$ Kolb, H. C.; Sharpless, K. B. Tetrahedron Lett. 1992, 48, 10515-10530.

${ }^{37}$ Aggarwal, V. K.; Alonso, E.; Hynd, G.; Lydon, K. M.; Palmer, M. J.; Porcelloni, M.; Studley, J. R. Angew. Chem. Int. Ed. Engl. 2001, 40, 1430-1433.
} 
Several methods for kinetic resolution and desymmetrisation of epoxides have also evolved. ${ }^{38}$

\subsubsection{Ring-opening of epoxides}

Ring-opening reactions of epoxides have been performed with a large variety of nucleophiles. ${ }^{4,39}$ The regioselectivity can often be controlled by appropriate choice of substituents on the oxirane ring; with alkyl substituents ring-opening proceeds at the sterically least hindered carbon atom, whereas conjugating substituents, e.g. phenyl and vinyl groups, promote ring opening at the adjacent carbon atom. ${ }^{40}$ In reactions with vinylepoxides, hard nucleophiles tend to add in a 1,2-fashion, while soft nucleophiles prefer 1,4-addition. ${ }^{14,41}$

\subsection{Synthesis of vinylepoxides 1}

In the present study, six substrates were designed to represent variations in substitution pattern and electronic influence (Figure 5). Vinylepoxides 1a,b exemplify differences in electronic character, whereas substrates $\mathbf{1 b}, \mathbf{c}$ depict variation of olefin substitution (terminal vs. internal). Influence of substitution at the allylic position is exemplified by 1d vs. 1e. This is an important feature, as the ring-opening reactions should take place regioselectively at this carbon atom. Finally the position of the vinyl group substituent was varied (1c-e vs. 1f). The substrates are represented by the general structure $\mathbf{1}$.

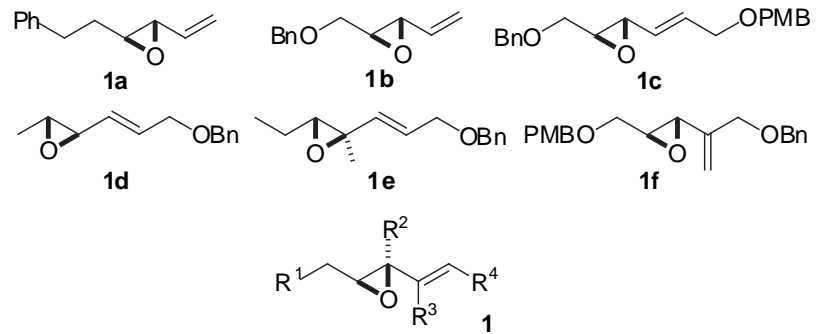

Figure 5. Vinylepoxides used in the present study.

The synthesis of vinylepoxides $\mathbf{1}$ is briefly described in Schemes 16 and 17 . The epoxidation step in each route is the key step of the synthesis, as the enantioselectivity obtained will be preserved throughout the remaining

38 (a) Hodgson, D. M.; Gibbs, A. R.; Lee, G. P. Tetrahedron 1996, 46, 14361-14384. (b) Schaus, S. E.; Brandes, B. D.; LArrow, J. F.; Tokunaga, M.; Hansen, K. B.; Gould, A. E.; Furrow, M. E.; Jacobsen, E. N. J. Am. Chem. Soc. 2002, 124, 1307-1315.

${ }^{39}$ (a) Prestat, G.; Baylon, C.; Heck, M.-P.; Mioskowski, C. Tetrahedron Lett. 2000, 41, 3829-3831. (b) Sabitha, G.; Babu, S.; Rajkumur, M.; Reddy, C. S.; Yadav, J. S. Tetrahedron Lett. 2001, 42, 3955-3958.

${ }^{40}$ Bandini, M.; Cozzi, P. G.; Melchiorre, P.; Umani-Ronchi, A. J. Org. Chem. 2002, 67, 5386-5389.

${ }^{41}$ Marshall, J. A. Chem. Rev. 1989, 89, 1503-1511. 
transformations leading to amino alcohols 2, 3, 5 and $\mathbf{6}$ (see Scheme 12). ${ }^{42}$

The synthetic routes to vinylepoxides 1a-c were designed to employ Sharpless asymmetric epoxidation (SAE). Hence 1a was obtained from 3-phenyl-propanol by a Swern/Horner-Emmons procedure followed by reduction to the corresponding allylic alcohol. This species was epoxidized under SAE conditions followed by Swern/Wittig to give 1a (Scheme 16a). ${ }^{43}$ Epoxide 1b was obtained from 2-butyne-1,4-diol by reduction and monobenzylation ${ }^{44}$ to reach the corresponding allylic alcohol, which was treated as above to yield $\mathbf{1 b}$ (Scheme $16 b) .^{43}$

Although being rather straightforward, this approach suffers from moderate yields in the final Wittig reaction, and is furthermore limited to synthesis of terminal vinylepoxides. Disubstituted $(E)$-olefins can be selectively obtained only with stabilized Wittig reagents, whereas non-stabilized Wittig reagents predominantly afford the undesired $(Z)$-isomers. ${ }^{45}$

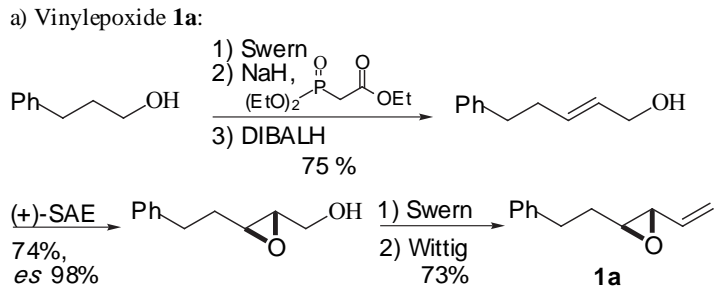

b) Vinylepoxide 1b:

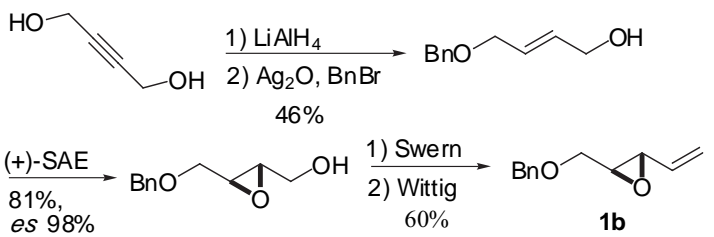

c) Vinylepoxide 1c:

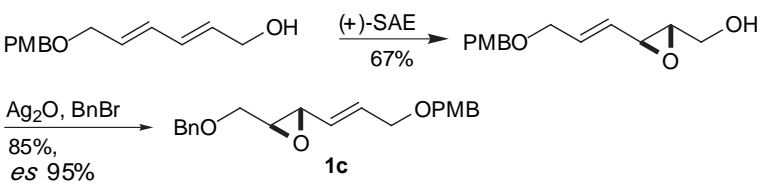

Scheme 16. Synthesis of vinylepoxides 1a-c.

\footnotetext{
${ }^{42}$ Vinylepoxides are rarely crystalline, which renders it difficult to increase the es by recrystallization. It is therefore of great importance to utilize epoxidation conditions that give high enantioselectivity.

${ }^{43}$ Lindström, U. M.; Somfai, P. Synthesis 1998, 109-117.

${ }^{44}$ Löfstedt, J.; Pettersson-Fasth, H.; Bäckvall, J.-E. Tetrahedron 2000, 56, 2225-2230.

${ }^{45}$ Only $(E)$-vinylepoxides can be employed within this strategy, as isomerization might occur during the $\operatorname{Pd}(0)$-catalyzed ring-opening of $(Z)$-vinylepoxides, see Chapter 4.1 and Tsuji, J. Palladium reagents and catalysts. Innovations in organic synthesis; John Wiley \& Sons Ltd: Chichester, 1995.
} 
Hence a modification of the route was needed to reach substrate 1c (Scheme 16c). SAE was thus performed on PMB-monoprotected hexa-2,4-dien-1,6-diol, which was produced from the corresponding ester. ${ }^{46}$ As described in Chapter 2.1, conjugated dienols are often poor substrates for SAE. The reaction was indeed sluggish, resulting in $45 \%$ epoxyalcohol and $37 \%$ starting material, i.e. $67 \%$ yield based on recovered dienol. Moreover, benzylation of this species was problematic, as standard conditions gave decomposition. ${ }^{47}$ Finally 1c could be isolated in $85 \%$ yield based on recovered starting material $(45 \%)$ using the milder $\mathrm{BnBr} / \mathrm{Ag}_{2} \mathrm{O}$ conditions. ${ }^{48}$

The synthesis of 1c was clearly unsatisfactory, and other routes were examined to obtain vinylepoxides 1d-f. Shi's monoepoxidation of dienes seemed ideal, as TMS-protected hexadienol could be epoxidized in good yield (see Scheme 15). ${ }^{35}$ Hexadienol was thus benzylated and exposed to catalyst 7, yielding $66 \%$ of $\mathbf{1 d}$ together with $10 \%$ of the corresponding regioisomer (Scheme 17a). ${ }^{49}$ Substrate 1e was synthesized from 2-methyl-2-pentenal by a Horner-Emmons reaction followed by reduction and benzylation. Epoxidation occurred with complete regioselectivity, reflecting the electronic influence exerted by the methyl group, and 1e was isolated in 100\% yield (Scheme 17b). This synthetic strategy was clearly superior to the previous one, being both shorter and having high-yielding steps.

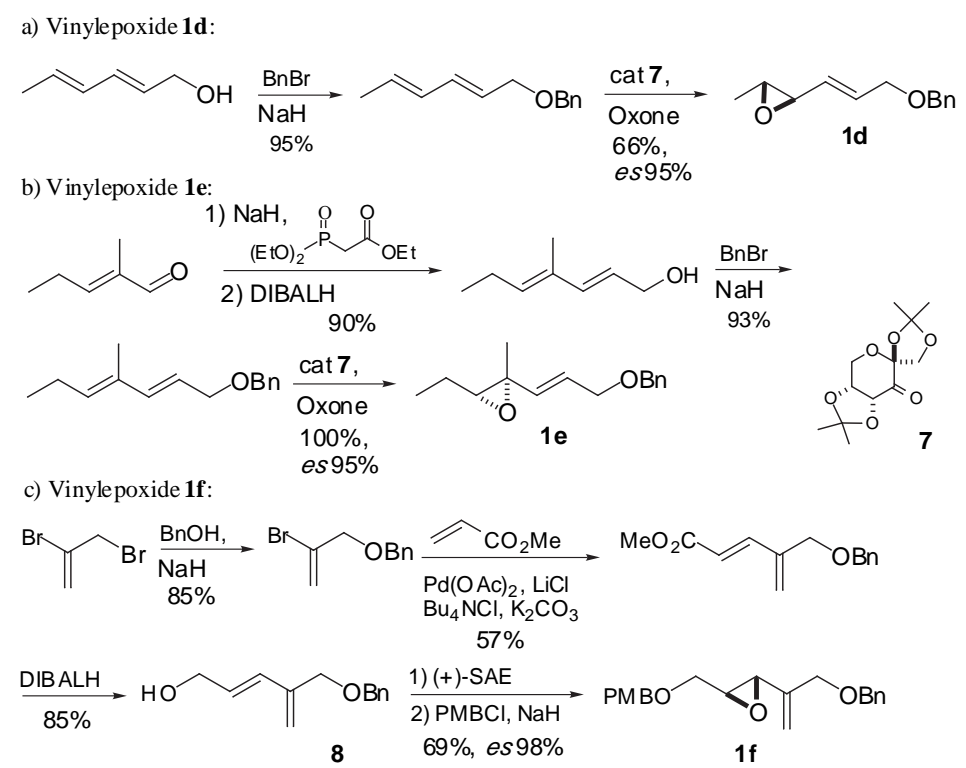

Scheme 17. Synthesis of vinylepoxides 1d-f.

\footnotetext{
${ }^{46}$ Lindström, U. M.; Somfai, P. Tetrahedron Lett. 1998, 39, 7173-7176.

${ }^{47} \mathrm{BnBr}, \mathrm{NaH}$, THF or DMF, heat.

${ }^{48}$ Bouzide, A.; Sauvé, G. Tetrahedron Lett. 1997, 38, 5945-5948.

${ }^{49}$ As 1d was unstable on silica, the yield decreased upon separation from the regioisomer.
} 
Vinylepoxide $\mathbf{1 f}$ was synthesized before $\mathbf{1 d , e ~ u s i n g ~ a ~ r e p o r t e d ~ s t r a t e g y . ~}{ }^{50}$ Starting from 2,3-dibromopropene, dienol $\mathbf{8}$ was made by sequential Williamson reaction, Heck coupling and reduction. This dienol was epoxidized under SAEconditions, after which PMB-protection resulted in $\mathbf{1 f}$ (Scheme 17c). ${ }^{51}$

In the microwave-assisted aminolysis study (Chapter 3.2), several additional vinylepoxides were used to investigate the scope and limitations of the reaction. These substrates (1g-k) were prepared from the corresponding allylic alcohols as described for 1a,b (Figure 6). ${ }^{43,52,53}$

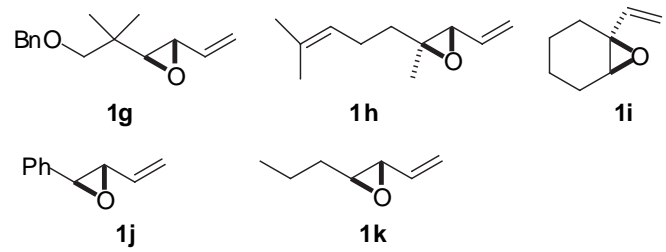

Figure 6. Structures of vinylepoxides $\mathbf{1 g - k}$.

\subsubsection{Determination of enantiomeric purity}

The enantiomeric purity of vinylepoxides 1a-c,f was estimated from measurements on the corresponding epoxyalcohols. Epoxidation of the allylic alcohols with mCPBA yielded the corresponding racemic epoxyalcohols, needed for HPLC-determination of es. Vinylepoxides 1d,e were compared with the corresponding racemic vinylepoxides, which were prepared by mCPBAepoxidation of the dienes.

ChiralCel OJ or OD-H columns were used in the HPLC-analysis, revealing enantioselectivities of $98 \%$ for vinylepoxides $\mathbf{1 a}, \mathbf{b}, \mathbf{f}$ and of $95 \%$ for $\mathbf{1 c}-\mathbf{e}$. The enantioselectivities obtained in the Shi epoxidation, yielding 1d,e, were thus slightly lower than in the epoxidation of the corresponding TMS-protected dienols (see Scheme 15). No attempts were made to optimize the selectivity.

\footnotetext{
${ }^{50}$ Weigand, S.; Bruckner, R. Synlett 1997, 225-228.

${ }^{51}$ Lindström, U. M.; Somfai, P. Chem. Eur. J. 2001, 7, 94-98.

${ }^{52}$ Lindström, U. M., Stockholm University, 2000.

${ }^{53}$ Vinylepoxide $1 \mathbf{i}$ is racemic and was prepared by mCPBA-epoxidation instead of SAE.
} 


\section{Aminolysis of Vinylepoxides 1 to anti-Amino Alcohols 2}

(Papers I-IV)

Epoxides are commonly ring-opened by sodium azide to afford azido alcohols, which can be reduced to the corresponding amino alcohols 4 . When vinylepoxides are treated with sodium azide, however, a mixture of products is obtained due to a thermal [3,3]-rearrangement of the allylic azide initially formed.$^{43}$ Alternatively, aminolysis can be performed with benzylamine followed by a deprotection step to give amino alcohols. ${ }^{2,43}$ Direct ring-opening with ammonia would be a shorter route to $\mathbf{2}$, although the reaction suffers from poor reactivity and high pressure.

\subsection{Conventional Aminolysis}

Stogryn and Brois showed that monosubstituted vinylepoxides could be ringopened using ammonium hydroxide..$^{54}$ With this procedure, vinylepoxide 1a gave amino alcohol 2a in only 13\% yield after 10 days (Table 1, entry 1), indicating that the reaction was too slow for synthetic purposes with disubstituted substrates. ${ }^{55}$ McManus et al. could open simple disubstituted epoxides by heating in neat ammonia with a stoichiometric amount of $\mathrm{H}_{2} \mathrm{O} .{ }^{56}$ As no reaction took place in the absence of water, they suggested the ammonium ion to be the active species. When 1a was heated in neat ammonia with water present, a slow reaction resulted in minor amounts of amino alcohol $\mathbf{2 a}$ with diols $\mathbf{9}$ as major products (entry 2$)^{.55}$

\footnotetext{
${ }^{54}$ Stogryn, E. L.; Brois, S. J. J. Am. Chem. Soc. 1967, 89, 605-609.

${ }^{55}$ Lindström, U. M.; Franckowiak, R.; Pinault, N.; Somfai, P. Tetrahedron Lett. 1997, 38, $2027-$ 2030.

${ }^{56}$ McManus, S. P.; Larson, C. Å.; Hearn, R. A. Synth. Commun. 1973, 3, 177-180.
} 
Table 1. Aminolysis of vinylepoxide 1a to anti-amino alcohol $\mathbf{2 a}$.

\begin{tabular}{|c|c|c|c|}
\hline \multirow[b]{2}{*}{ Entry } & \multirow[b]{2}{*}{ Conditions } & \multicolumn{2}{|c|}{ Yield $(\%)$} \\
\hline & & $2 \mathbf{a}$ & 9 \\
\hline 1 & $\mathrm{NH}_{4} \mathrm{OH}, \mathrm{rt} \rightarrow \Delta, 10 \mathrm{~d}$ & 13 & 0 \\
\hline 2 & $\mathrm{NH}_{3}, 2$ equiv $\mathrm{H}_{2} \mathrm{O}, 80{ }^{\circ} \mathrm{C}, 3 \mathrm{~d}$ & 11 & 62 \\
\hline 3 & $\mathrm{NH}_{3}, 0.05$ equiv TsOH$\cdot \mathrm{H}_{2} \mathrm{O}, 130^{\circ} \mathrm{C}, 3 \mathrm{~d}$ & 77 & 10 \\
\hline 4 & $\mathrm{NH}_{4} \mathrm{OH}, 25 \mathrm{~W}, 8 \mathrm{~min}$. & 93 & 0 \\
\hline
\end{tabular}

Gratifyingly, when 1a was heated in neat ammonia and $\mathrm{TsOH} \cdot \mathrm{H}_{2} \mathrm{O}(0.05$ equiv), 2a could be isolated in $77 \%$ yield after 3 days, together with $10 \%$ of diols 9 (entry 3)..$^{55,57}$ The method was applied to several substrates, regioselectively and diastereospecifically affording the corresponding amino alcohols $\mathbf{2}$ (Table 2).

Although high yields were obtained for unhindered epoxides 1a,b,f, the scope of the reaction is limited as it requires prolonged heating in neat ammonia, and when sterically hindered substrates $\mathbf{1 g}, \mathbf{h}$ are used, the reaction is almost completely retarded (entries 7,8). In order to make the aminolysis more synthetically useful, the development of a reaction less sensitive to steric hindrance and with shorter reaction time was needed.

\subsection{Microwave-assisted aminolysis}

In recent years, the application of microwave-assisted reactions to organic synthesis has received considerable attention. Compared with conventional heating, microwave irradiation often gives greatly enhanced reaction rates and less byproducts. ${ }^{58}$ Pleasingly, when 1a was treated with ammonium hydroxide under microwave irradiation, 2 a was obtained in 93\% yield in only 8 min (Table 1, entry 4). Di-and trisubstituted vinylepoxides $\mathbf{1} \mathbf{b}-\mathbf{k}$ were also subjected to microwave irradiation in $\mathrm{NH}_{4} \mathrm{OH}$. Complete conversion into amino alcohols $\mathbf{2 b}$ g was generally obtained within 8 min (Table 2).

The yields from unhindered substrates $\mathbf{1 a}, \mathbf{b}, \mathbf{f}$ are better or as good as with conventional heating (entries 1,2,6). More sterically hindered substrates also seem to be efficiently converted into amino alcohols, as derivative $\mathbf{1 g}$ gave $\mathbf{2} \mathbf{g}$ in $90 \%$ yield compared with only $23 \%$ after 4 days in neat ammonia at $130{ }^{\circ} \mathrm{C}$ (entry 3). The procedure is effective even with trisubstituted substrates, as exemplified by 2,2,3-trisubstitued vinylepoxide $\mathbf{1 h}$ that afforded $\mathbf{2 h}$ in $76 \%$ yield (entry 7). Not surprisingly, 2,3,3-trisubstitued substrates 1e,i, having quaternary allylic carbons, reacted to give $\mathbf{2 e}, \mathbf{i}$ as regioisomeric mixtures (entries 5,9).

Aminolysis of $\mathbf{1} \mathbf{j}$ resulted in a $2: 1$ mixture of amino alcohol $\mathbf{2} \mathbf{j}$ and its

\footnotetext{
${ }^{57}$ Anhydrous TsOH did not catalyze the reaction.

${ }^{58}$ Caddick, S. Tetrahedron 1995, 51, 10403-10432.
} 
regioisomer, reflecting a competition between the allylic and benzylic positions (entry 10). Unexpectedly, reaction of substrates $\mathbf{1 d}, \mathbf{k}$ also resulted in regioisomeric mixtures, the explanation being less obvious. Ring-opening in the homoallylic position could be suppressed in both cases by lowering of the irradiation power, which increased the regioisomeric ratios $(\mathbf{1 d} 6: 1 \rightarrow 11: 1, \mathbf{1 k}$ $6: 1 \rightarrow 9: 1)$.

Table 2: Comparison of aminolysis yields using conventional or microwave heating.

\begin{tabular}{|c|c|c|c|c|}
\hline \multirow[t]{2}{*}{ Entry } & & \multirow[t]{2}{*}{ Vinylepoxide } & \multicolumn{2}{|c|}{ Yield (\%) / Ratio ${ }^{a}$} \\
\hline & & & Conventional $^{\mathrm{b}}$ & Microwave $^{c}$ \\
\hline 1 & $1 \mathbf{a}$ & & $77^{\mathrm{d}}$ & 93 \\
\hline 2 & $1 b$ & & 93 & 87 \\
\hline 3 & 1c & & - & 88 \\
\hline \multirow[t]{2}{*}{4} & 1d & & - & 88 \\
\hline & & & & $11: 1$ \\
\hline \multirow[t]{2}{*}{5} & $1 \mathrm{e}$ & & - & 100 \\
\hline & & & & $2: 1$ \\
\hline 6 & 1f & & 86 & 84 \\
\hline 7 & $1 g$ & & $23^{\mathrm{e}}$ & 90 \\
\hline 8 & 1h & & 25 & 76 \\
\hline \multirow[t]{2}{*}{9} & $\mathbf{1 i}$ & & - & 77 \\
\hline & & & & $1: 1$ \\
\hline \multirow[t]{2}{*}{10} & $\mathbf{1 j}$ & & 70 & 98 \\
\hline & & & $2: 1$ & $2: 1$ \\
\hline \multirow[t]{2}{*}{11} & $1 k$ & & 75 & 95 \\
\hline & & & $5: 1$ & $9: 1$ \\
\hline
\end{tabular}

a Isolated yields/ regioisomeric ratio. ${ }^{\mathrm{b}} \mathrm{NH}_{3}$, TsOH$\cdot \mathrm{H}_{2} \mathrm{O}\left(0.05\right.$ equiv), $130{ }^{\circ} \mathrm{C}, 3$ days. ${ }^{\mathrm{c}} \mathrm{NH}_{4} \mathrm{OH}, 15-30 \mathrm{~W}, 8-15 \mathrm{~min} .{ }^{\mathrm{d}} 80{ }^{\circ} \mathrm{C}$. ${ }^{\mathrm{e}} 4$ days.

With this protocol the synthesis of anti-amino alcohols $\mathbf{2}$ has been greatly improved due to simplified handling, short reaction times and high yielding reactions also with sterically hindered substrates.

\subsection{Large Scale Aminolysis}

Microwave chemistry can be difficult to perform on a large scale, as the concentration influences the power needed for full conversion. ${ }^{59}$ Therefore the

${ }^{59}$ The microwave cavity cannot be scaled up. 
aminolysis reaction was further investigated using vinylepoxides $\mathbf{1 a}, \mathbf{b}$. As aminolysis of epoxides has been performed in various organic solvents with secondary amines, ${ }^{60}$ our first strategy involved the use of protic solvents and excess ammonium hydroxide. Pleasingly, when 1a was subjected to 10 equiv $\mathrm{NH}_{4} \mathrm{OH}$ in $\mathrm{EtOH}$ at $70{ }^{\circ} \mathrm{C}$ in a sealed flask, slow formation of $\mathbf{2 a}$ occurred. The reaction rate could be increased by the use of a large excess of $\mathrm{NH}_{4} \mathrm{OH}$, which yielded $\mathbf{2 a}$ in $73 \%$ after $48 \mathrm{~h}$ heating. Addition of a catalytic amount of $\mathrm{TsOH} \cdot \mathrm{H}_{2} \mathrm{O}$ caused formation of the corresponding diol without increasing the formation rate of $\mathbf{2} \mathbf{a} .{ }^{61}$ Compared with the original procedure with neat ammonia, the use of excess $\mathrm{NH}_{4} \mathrm{OH}$ in protic solvents simplified the handling without shortening the reaction time.

Not satisfied with these results, we investigated whether there was a microwave effect ${ }^{62}$ in the aminolysis reaction, or whether it would proceed with conventional heating. The maximum temperature reached in microwave reactions in $\mathrm{NH}_{4} \mathrm{OH}$ at $50 \mathrm{~W}$ for 8 min was $170{ }^{\circ} \mathrm{C}$, and when vinylepoxide $\mathbf{1 b}$ in $\mathrm{NH}_{4} \mathrm{OH}$ was heated to $170{ }^{\circ} \mathrm{C}$ in a sealed metal cylinder, $2 \mathbf{b}$ could be isolated in $93 \%$ yield after only $4.5 \mathrm{~h}$ reaction time (Table 3 , entry 2 ). This procedure was applied to vinylepoxide 1d, giving $\mathbf{2 d}$ in $72 \%$ yield and 6:1 regioselectivity after only $1 \mathrm{~h}$ heating (entry 4 ). The result could easily be improved to $82 \%$ and 9:1 regioselectivity by decreasing the temperature to $140{ }^{\circ} \mathrm{C}$, which was sufficient also for the ring-opening of $\mathbf{1 e}$ (entry 5). The reaction temperature could be decreased even further, and amino alcohol $\mathbf{2 a}$ was isolated in excellent yield after $1 \mathrm{~h}$ at only $125^{\circ} \mathrm{C}$ (entry 1$) .^{63}$

Table 3. Aminolysis of vinylepoxides 1 to anti-amino alcohols $\mathbf{2}$.

\begin{tabular}{|c|c|c|c|c|c|c|c|}
\hline \multirow[t]{2}{*}{ Entry } & \multirow[t]{2}{*}{ Substrate } & \multirow[t]{2}{*}{$\mathbf{R}^{1}$} & \multirow[t]{2}{*}{$\mathbf{R}^{2}$} & \multirow[t]{2}{*}{$\mathbf{R}^{3}$} & \multirow[t]{2}{*}{$\mathbf{R}^{4}$} & \multicolumn{2}{|c|}{ Yield of $2(\%)^{a}$} \\
\hline & & & & & & Microw. $^{b}$ & Oilbath $^{\mathrm{c}}$ \\
\hline 1 & $1 \mathbf{a}$ & $\mathrm{PhCH}_{2}$ & $\mathrm{H}$ & $\mathrm{H}$ & $\mathrm{H}$ & 93 & $91^{\mathrm{d}}$ \\
\hline 2 & $1 b$ & $\mathrm{BnO}$ & $\mathrm{H}$ & $\mathrm{H}$ & $\mathrm{H}$ & 87 & 93 \\
\hline 3 & 1c & $\mathrm{BnO}$ & $\mathrm{H}$ & $\mathrm{H}$ & $\mathrm{CH}_{2} \mathrm{OPMB}$ & 88 & - \\
\hline 4 & 1d & $\mathrm{H}$ & $\mathrm{H}$ & $\mathrm{H}$ & $\mathrm{CH}_{2} \mathrm{OBn}$ & $100^{\mathrm{d}}$ & $82^{\mathrm{e}}$ \\
\hline 5 & 1e & $\mathrm{Me}$ & $\mathrm{Me}$ & $\mathrm{H}$ & $\mathrm{CH}_{2} \mathrm{OBn}$ & $89^{\mathrm{f}}$ & $78^{f}$ \\
\hline 6 & 1f & PMBO & $\mathrm{H}$ & $\mathrm{CH}_{2} \mathrm{OBn}$ & $\mathrm{H}$ & 84 & - \\
\hline
\end{tabular}

asolated yields. ${ }^{\mathrm{b}} 20-30 \mathrm{~W}, 8-15 \mathrm{~min} .{ }^{\mathrm{c}} 125-170{ }^{\circ} \mathrm{C}, 1-4.5$ h. ${ }^{\mathrm{d}}$ Regioisomeric mixture 11:1. ${ }^{\mathrm{e}}$ Regioisomeric mixture 9:1. ${ }^{\mathrm{f}}$ Regioisomeric mixture 2:1

${ }^{60}$ (a) Sekar, G.; Singh, V. K. J. Org. Chem. 1999, 64, 287-289. (b) Cristau, H.-J.; Pirat, J.-L.; Drag, M.; Kafarski, P. Tetrahedron Lett. 2000, 41, 9781-9785.

${ }^{61}$ Change of solvent to 2-methoxyethanol, to increase the boiling point, did not improve the results.

${ }^{62}$ Kuhnert, N. Angew. Chem. Int. Ed. Engl. 2002, 41, 1863-1866.

${ }^{63}$ Due to difficulties in monitoring reactions in sealed tubes, reaction temperatures and times were not optimized further. 
These results clearly indicate the absence of a microwave effect; the reaction probably takes place instantly when the temperature needed to dissolve the vinylepoxides has been reached. The regioisomeric mixtures obtained with some substrates can most likely be further optimized by fine-tuning of reaction temperature and time. This novel aminolysis method is the first practical largescale protocol described for ring-opening of vinylepoxides with ammonia. The reaction is fast, stereospecific and highly regioselective. Furthermore, no special equipment is needed, as the pressure reached at $125{ }^{\circ} \mathrm{C}$ in $\mathrm{NH}_{4} \mathrm{OH}$ is moderate. ${ }^{64}$

${ }^{64}$ We now use glass tubes with plastic screw-caps; a metal cylinder is not needed. 


\section{Pd(0)-catalyzed Epoxide Opening leading to syn-Amino Alcohols 3}

(Papers II-IV)

Syn-amino alcohols $\mathbf{3}$ can be obtained by ring-opening of vinylepoxides $\mathbf{1}$ with retention of configuration (see Scheme 12). This can be achieved via a palladium-catalyzed reaction that proceeds with double inversion.

\subsection{Pd(0)-catalyzed Ring-Opening of 1}

Palladium-catalyzed, nucleophilic ring-openings of vinylepoxides are discussed in a recent review. ${ }^{65}$ The reaction is initiated by formation of a $\pi$-allyl palladium complex, which is attacked by the nucleophile. 1,4-Addition is often encountered, although this can be avoided by choice of an appropriate nucleophile.

$\operatorname{Pd}(0)$-catalyzed ring-opening of vinylepoxides $\mathbf{1}$ in the presence of tosyl isocyanate results in formation of oxazolidinones $\mathbf{1 0}$, as depicted in Scheme $18 .{ }^{66,67}$ Tosyl isocyanate reacts with the $\pi$-allyl palladium complex $\mathbf{A}$ initially formed, to give intermediate $\mathbf{B}$. This species subsequently ring-closes with retention of the original configuration to $N$-tosyl oxazolidinones 10. 1,4-Addition of the nucleophile is thus avoided by attachment to the oxygen prior to attack.

\footnotetext{
${ }^{65}$ Trost, B. M. Chem. Rev. 1996, 96, 395-422.

${ }^{66}$ Trost, B. M.; Sudhakar, A. R. J. Am. Chem. Soc. 1987, 109, 3792-3794.

${ }^{67}$ Trost, B. M.; Sudhakar, A. R. J. Am. Chem. Soc. 1988, 110, 7933-7935.
} 


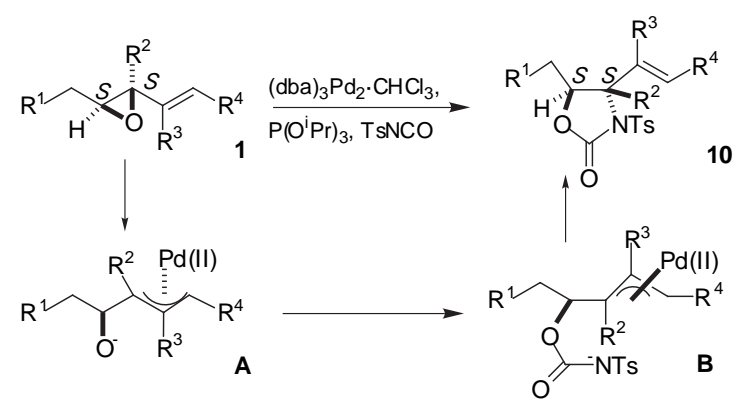

Scheme 18: Palladium(0)-catalyzed epoxide opening with tosyl isocyanate.

When the terminal vinylepoxides 1a,b were treated with $\operatorname{Pd}(0)$, oxazolidinones 10a,b were obtained in good yields, although as unseparable diastereomeric mixtures (Table 4, entries 1,2). Optimization of the reaction conditions only resulted in a slight improvement of the diastereoselectivity. ${ }^{68}$

Gratifyingly, the initial product mixtures could be equilibrated at reflux, thus favoring the more stable ${ }^{67}$ trans-oxazolidinones. In this manner, the kinetically obtained, poor ratios could be significantly enhanced (1a $d r 2: 1 \rightarrow 6: 1,1 \mathbf{b} d r$ $2: 1 \rightarrow 14: 1){ }^{69}$ A recently published study of a $\mathrm{Pd}(0)$-catalyzed transformation of vinyloxazolidinones into vinyloxazolines showed the same equilibration trend; when $\mathrm{R}^{1}$ changed from alkoxy to alkyl the selectivity decreased..$^{70}$ To prove this trend further, vinylepoxide $\mathbf{1 k}$ (see Chapter 2) was exposed to the reaction conditions. The corresponding oxazolidinone was indeed formed with poor diastereoselectivity $(d r 1.7)$, which could not be improved by equilibration attempts. ${ }^{71}$

Table 4. Synthesis of oxazolidinones 10.

\begin{tabular}{ccccccc}
\hline Entry & Substrate & $\mathbf{R}^{\mathbf{1}}$ & $\mathbf{R}^{\mathbf{2}}$ & $\mathbf{R}^{\mathbf{3}}$ & $\mathbf{R}^{\mathbf{4}}$ & Yield of 10 (\%) $^{\mathrm{a}}$ \\
\hline 1 & $\mathbf{1 a}$ & $\mathrm{PhCH}_{2}$ & $\mathrm{H}$ & $\mathrm{H}$ & $\mathrm{H}$ & $82^{\mathrm{b}}$ \\
2 & $\mathbf{1 b}$ & $\mathrm{BnO}$ & $\mathrm{H}$ & $\mathrm{H}$ & $\mathrm{H}$ & $88^{\mathrm{c}}$ \\
3 & $\mathbf{1 c}$ & $\mathrm{BnO}$ & $\mathrm{H}$ & $\mathrm{H}$ & $\mathrm{CH}_{2} \mathrm{OPMB}$ & 87 \\
4 & $\mathbf{1 d}$ & $\mathrm{H}$ & $\mathrm{H}$ & $\mathrm{H}$ & $\mathrm{CH}_{2} \mathrm{OBn}$ & $62^{\mathrm{d}}$ \\
5 & $\mathbf{1 e}$ & $\mathrm{Me}$ & $\mathrm{Me}$ & $\mathrm{H}$ & $\mathrm{CH}_{2} \mathrm{OBn}$ & 94 \\
6 & $\mathbf{1 f}$ & $\mathrm{PMBO}$ & $\mathrm{H}$ & $\mathrm{CH}_{2} \mathrm{OBn}$ & $\mathrm{H}$ & 93 \\
\hline
\end{tabular}

${ }^{\mathrm{a}}$ Isolated yields. ${ }^{\mathrm{b}} d r 6: 1 .{ }^{\mathrm{c}} d r$ 14:1. ${ }^{\mathrm{d}} \mathrm{See}$ text.

Pleasingly, when 1 contained additional vinylic substituents (1c-f, entries 3$6)$, conversion of $\mathbf{1}$ to $\mathbf{1 0}$ took place with complete diastereoselectivity (>95\%), except in the case of oxazolidinone 10d, which was formed along with (Z)-4,5-

\footnotetext{
${ }^{68}$ Temperature, amounts of catalyst, ligand and TsNCO were varied independently.

${ }^{69}$ Equilibration was performed with the catalyst at reflux for 2-5 days, where longer reflux time gave better $d r$ but also caused more degradation of the product.

${ }^{70}$ Cook, G. R.; Shanker, S. Tetrahedron Lett. 1998, 39, 3405-3408.

71 For $a b$ initio calculations on the mechanism of $\eta^{3}-\eta^{1}-\eta^{3}$ isomerizations in allylpalladium complexes, see Solin, N.; Szabó, K. J. Organometallics 2001, 20, 5464-5471.
} 
cis-oxazolidinone 11 (Figure 7). To the best of our knowledge, an $E \rightarrow Z$ isomerization had not previously been reported in this reaction. As opposed to the equilibration results above, the byproduct ratio could be improved by decreasing the temperature $(3: 1 \rightarrow 9: 1)$.

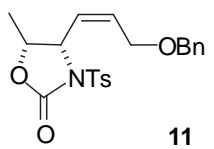

Figure 7. (Z)-4,5-cis-oxazolidinone 11.

\subsection{Detosylation and Hydrolysis}

Amino alcohols $\mathbf{3}$ could in principle be obtained from $\mathbf{1 0}$ either by sequential detosylation and hydrolysis, or by hydrolysis prior to detosylation. The latter sequence proved inferior; as the corresponding $N$-tosyl amino alcohols were less reactive than $\mathbf{1 0}$ in the detosylation, they could not be selectively deprotected.

Detosylation of oxazolidinones 10 to $\mathrm{N}-\mathrm{H}$ oxazolidinones $\mathbf{1 2}$ was effected by titration with sodium naphthalide solution at $-78{ }^{\circ} \mathrm{C}$ (Scheme 19, Table 5). ${ }^{72}$ At this stage the diastereomers of $\mathbf{1 2 a}, \mathbf{b}$ could be separated by flash chromatography. Due to troublesome purification of $N$-tosyl oxazolidinone 10d from byproduct 11, the best yield from 1d to 12d was obtained when 10d was not isolated (entry 4).

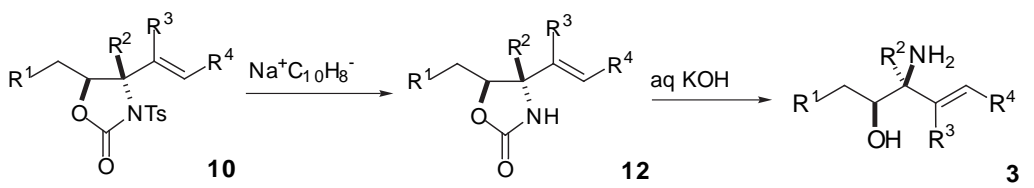

Scheme 19: Detosylation of $\mathbf{1 0}$ into 12 and hydrolysis to syn-amino alcohols 3.

Subsequent hydrolysis of $N$-H oxazolidinones $\mathbf{1 2}$ into $s y n$-amino alcohols $\mathbf{3}$ was examined both under basic and acidic conditions. The basic hydrolysis was superior, giving 3 in excellent yields (Scheme 19, Table 5). Hydrolysis of 12e was retarded due to sterical hindrance; $8 \mathrm{~h}$ reflux were needed for completion compared to $1 \mathrm{~h}$ for $\mathbf{1 2 a}-\mathbf{d}, \mathbf{f}$ (entry 5).

${ }^{72}$ To avoid degradation/ debenzylation, the reaction time should be kept short. See Heathcock, C. H.; Blumenkopf, T. A.; Smith, K. M. J. Org. Chem. 1989, 54, 1548-1562. 
Table 5. Detosylation and hydrolysis to $s y n$-amino alcohols 3.

\begin{tabular}{ccccccccc}
\hline Entry & Substrate & $\mathbf{R}^{\mathbf{1}}$ & $\mathbf{R}^{\mathbf{2}}$ & $\mathbf{R}^{\mathbf{3}}$ & $\mathbf{R}^{\mathbf{4}}$ & \multicolumn{2}{c}{ Yield (\%) } \\
\cline { 3 - 7 } & & & & & $\mathbf{1 2}$ & $\mathbf{3}$ \\
\hline 1 & $\mathbf{1 a}$ & $\mathrm{PhCH}_{2}$ & $\mathrm{H}$ & $\mathrm{H}$ & $\mathrm{H}$ & $93^{\mathrm{b}}$ & 100 \\
2 & $\mathbf{1 b}$ & $\mathrm{BnO}$ & $\mathrm{H}$ & $\mathrm{H}$ & $\mathrm{H}$ & $75^{\mathrm{b}}$ & 97 \\
3 & $\mathbf{1 c}$ & $\mathrm{BnO}$ & $\mathrm{H}$ & $\mathrm{H}$ & $\mathrm{CH}_{2} \mathrm{OPMB}$ & 72 & 91 \\
4 & $\mathbf{1 d}$ & $\mathrm{H}$ & $\mathrm{H}$ & $\mathrm{H}$ & $\mathrm{CH}_{2} \mathrm{OBn}$ & $61^{\mathrm{c}}$ & 95 \\
5 & $\mathbf{1 e}$ & $\mathrm{Me}$ & $\mathrm{Me}$ & $\mathrm{H}$ & $\mathrm{CH}_{2} \mathrm{OBn}$ & 80 & 98 \\
6 & $\mathbf{1 f}$ & $\mathrm{PMBO}$ & $\mathrm{H}$ & $\mathrm{CH}_{2} \mathrm{OBn}$ & $\mathrm{H}$ & 84 & 86 \\
\hline
\end{tabular}

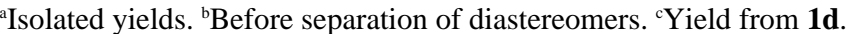




\section{Ring-closure of anti-Amino Alcohols 2 to Vinylaziridines 4}

(Papers II-V)

The two remaining amino alcohols, $\mathbf{5}$ and $\mathbf{6}$, are the regioisomers of $\mathbf{2}$ and $\mathbf{3}$. We envisaged the synthesis of $\mathbf{5}$ and $\mathbf{6}$ by regioselective ring-opening of $N-\mathrm{H}$ vinylaziridines $\mathbf{4}$, which can be obtained from anti-amino alcohols 2 (see Scheme 12).

\subsection{Background to aziridines}

Aziridines are versatile synthetic intermediates, as the relief of ring-strain provides a driving force for efficient ring-opening or ring-expansion reactions. ${ }^{73,74}$ The importance of aziridines is also well recognized in asymmetric synthesis, where the need for chiral auxiliaries and ligands is continuously increasing. ${ }^{75}$

Vinylaziridines constitute an important subclass of aziridines, and have proven to be useful intermediates for various types of natural and synthetic compounds. ${ }^{76}$ Vinylaziridines can be selectively ring-opened at the allylic position (see Chapters 6 and 7), take part in conjugate addition reactions, ${ }^{77}$ Wittig and Claisen rearrangements, ${ }^{51,78}$ furthermore the vinyl group can be derivatized

\footnotetext{
73 (a) Rai, K. M. L.; Hassner, A. Advances in Strained and Interesting Organic Molecules 2000, 8 , 187-257. (b) McCoull, W.; Davis, F. A. Synthesis 2000, 1347-1365.

${ }^{74}$ Mahadevan, V.; Getzler, Y. D. Y. L.; Coates, G. W. Angew. Chem. Int. Ed. Engl. 2002, 41, 27812784 .

75 Tanner, D.; Birgersson, C.; Gogoll, A. Tetrahedron 1994, 50, 9797-9824.

${ }^{76}$ (a) Ibuka, T.; Nakai, K.; Habashita, H.; Hotta, Y.; Fujii, N.; Nimura, N.; Miwa, Y.; Taga, T.; Yamamoto, Y. Angew. Chem. Int. Ed. Engl. 1994, 33, 652-654. (b) Somfai, P.; Åhman, J. In Targets in Heterocyclic Systems; Italian Society of Chemistry: 1999, p 341-367.

${ }^{77}$ Aoyama, H.; Mimura, N.; Ohno, H.; Ishii, K.; Toda, A.; Tamamura, H.; Otaka, A.; Fujii, N.; Ibuka,

T. Tetrahedron Lett. 1997, 38, 7383-7386.

78 Åhman, J.; Jarevång, T.; Somfai, P. J. Org. Chem. 1996, 61, 8148-8159.
} 
into interesting functionalities. ${ }^{79}$

Existing enantioselective synthetic routes to aziridines include asymmetric aziridination of alkenes and ring-closure of vicinal hydroxy azides or amino alcohols. $^{73,80,81}$ Direct cyclization of $\beta$-amino alcohols into $N$-H aziridines is known to be difficult, having neither a nitrogen activating group nor a good leaving group. ${ }^{82,83,84} \mathrm{~N}$-substituted aziridines can on the other hand be synthesized from amino alcohols in various ways, ${ }^{80,81}$ and the plethora of methods encouraged us to perform a comparative study to find out which procedure is the most effective in formation of $\mathrm{N}$-H vinylaziridines.

\subsection{Investigation of ring-closure strategies}

$N$-H Vinylaziridines are rather acid labile, which limits the number of applicable protocols. We chose amino alcohol $\mathbf{2 a}$ as model substrate, and the desired transformation to aziridine $\mathbf{4 a}$ is shown in Scheme 20.

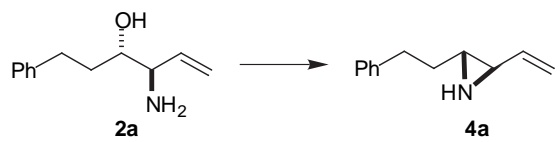

Scheme 20: Ring-closure of amino alcohol 2a to aziridine $4 \mathbf{a}$.

The transformation can be conducted in three general ways: 1) direct ringclosure of amino alcohol $\mathbf{2 a}$ to yield aziridine $\mathbf{4 a}$ is the most effective strategy, but suffers from the low reactivity of $\mathbf{2 a}$ towards ring-closure, as mentioned above. 2) Transformation of the hydroxy group of $\mathbf{2 a}$ into a better leaving group, which should facilitate ring-closure. 3) Protection of the amino moiety of $\mathbf{2 a}$ is expected to increase the reactivity towards ring-closure, although a deprotection step is needed to yield 4a. To compete with direct ring-closure, the two latter methods need high-yielding reaction steps, as several transformations are needed to achieve the desired product.

\subsubsection{Direct ring-closure}

Direct ring-closure of amino alcohols to $\mathrm{N}$-H aziridines is reported to proceed in moderate yields. This transformation was of major interest in our group, and hence a reaction utilizing Mitsunobu conditions was investigated. ${ }^{84,85}$ Initial attempts to ring-close $\mathbf{2 a}$ were disappointing, but moderate yields of $\mathbf{4 a}$ could be

\footnotetext{
${ }^{79}$ Patai, S. The Chemistry of Alkenes; Wiley: New York:, 1964; Vol. 1.

${ }^{80}$ Osborn, H. M. I.; Sweeney, J. Tetrahedron: Asymmetry 1997, 8, 1693-1715.

${ }^{81}$ Ibuka, T.; Mimura, N.; Aoyama, H.; Akaji, M.; Ohno, H.; Miwa, Y.; Taga, T.; Nakai, K.;

Tamamura, H.; Fujii, N.; Yamamoto, Y. J. Org. Chem. 1997, 62, 999-1015.

${ }^{82}$ Pearson, W. H.; Lian, B. W.; Bergmeier, S. C. Pergamon 1996, 1-96.

${ }^{83}$ Tanner, D. Angew. Chem. Int. Ed. Engl. 1994, 33, 599-619.

${ }^{84}$ Hughes, D. L. Org. Prep. Proc. Int. 1996, 28, 127-164.

${ }^{85}$ Mitsunobu, O. Synthesis 1981, 1-28.
} 
obtained in toluene at reflux. ${ }^{43}$ A carbamate byproduct was irregularly formed in considerable amounts due to reaction between the amino alcohol and DEAD; 43,85 this could be prevented by changing the ethyl groups of the azo compound to the bulkier isopropyl groups in DIAD. The reaction rate was increased by change of solvent from toluene to THF; this might reflect the observation of improved solubility of $\mathbf{2 a}$. Unfortunately, purification of $\mathbf{4 a}$ demanded repeated flash chromatography to remove the triphenylphosphine oxide formed, which decreased the isolated yield considerably.

We suspected $N-\mathrm{H}$ vinylaziridines to be unstable on silica, and indeed careful purification on deactivated silica could improve the yield of $\mathbf{4 a} .{ }^{86}$ Small-scale reactions were purified to give aziridine $\mathbf{4 a}$ in $80 \%$ yield, whereas large-scale reactions afforded $\mathbf{4 a}$ in $70 \%$ yield. To avoid the tedious purification, polymer bound triphenylphosphine was utilized. As expected, this decreased the reaction rate, but resulted in an easily purified crude product.

\subsubsection{Selective activation of the hydroxy group}

This strategy relies on the possibility of activating the hydroxy group without substituting the amino group. This limits the number of useful routes considerably, as the amino group is more reactive towards most activating agents e.g. tosyl chloride.

One solution of this delicate problem is reaction of $\mathbf{2 a}$ with chlorosulfonic acid to form sulfate ester 13 (Scheme 21). This compound can subsequently be ring-closed to aziridine $\mathbf{4 a}$ under basic conditions, as reported in formation of 2 vinylaziridine.$^{54}$ Formation of salt $\mathbf{1 3}$ was nearly quantitative, but ring-closure with excess $\mathrm{NaOH}$ at reflux furnished 4a in moderate yield (Table 6, entry 1). Various solvents and bases were screened, and the best result was achieved with $\mathrm{NaOH}$ in toluene/water, which gave aziridine $4 \mathbf{a}$ in $76 \%$ isolated yield (entry 2). ${ }^{87}$ Attempts using lower temperature, decreased amount of $\mathrm{NaOH}$ or other solvents, all decreased the yield (entry 3 ). The use of $n$-BuLi in THF resulted in $50 \%$ yield (entry 4); all other attempts were fruitless (entries 5-8).

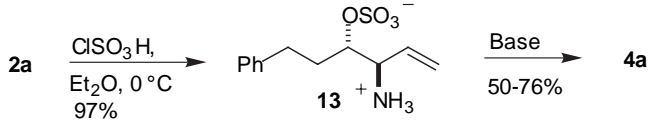

Scheme 21: Hydroxy group activation prior to ring-closure.

Ring-closure of 2a with selective activation of the hydroxy group accordingly yielded $\mathbf{4 a}$ in $74 \%$ over two steps, using the conditions stated in Table 6, entry 2.

\footnotetext{
${ }^{86}$ The drawback of using deactivated silica is decreased separation ability.

${ }^{87}$ Aziridine 4a was found to be volatile, the yield was improved when the toluene was removed carefully, followed by flash chromatography with Et2O instead of EtOAc.
} 
Table 6: Conditions for ring-closure of $\mathbf{1 3}$ to $\mathbf{4 a}$.

\begin{tabular}{cllc}
\hline Entry & Solvent $^{\mathrm{a}}$ & Base & Yield of 4a (\%) \\
\hline 1 & $\mathrm{H}_{2} \mathrm{O}$ & $\mathrm{NaOH}^{\mathrm{c}}$ & 58 \\
2 & Toluene/ $\mathrm{H}_{2} \mathrm{O}$ & $\mathrm{NaOH}^{\mathrm{c}}$ & 76 \\
3 & $\mathrm{THF} / \mathrm{H}_{2} \mathrm{O}^{\mathrm{d}}$ & $\mathrm{NaOH}^{\mathrm{c}}$ & 0 \\
4 & $\mathrm{THF}^{\mathrm{e}}$ & $n-\mathrm{BuLi}^{\mathrm{f}}$ & 50 \\
5 & $\mathrm{THF}$ & $\mathrm{NaOEt}^{\mathrm{f}}$ & $<5$ \\
6 & Toluene & $\mathrm{KO}^{\mathrm{t}} \mathrm{Bu}^{\mathrm{f}}$ & 0 \\
7 & Toluene & $\mathrm{Et}_{3} \mathrm{~N}^{\mathrm{g}}$ & $<5$ \\
8 & DMF & $\mathrm{K}_{2} \mathrm{CO}_{3}$ & $<5$ \\
\hline
\end{tabular}

${ }^{a}$ Reactions performed at reflux unless otherwise stated. ${ }^{\mathrm{b}}$ Isolated yields except in entry 1 , which was determined by HPLC. ${ }^{\mathrm{c}} \mathrm{Ex}-$ cess. ${ }^{\mathrm{d}} 100{ }^{\circ} \mathrm{C}$ in sealed flask. ${ }^{\mathrm{e}}-50{ }^{\circ} \mathrm{C}$ to rt. ${ }^{\mathrm{f}} 2.5$ equiv. ${ }^{\mathrm{g}} 3$ equiv.

\subsubsection{Selective protection of the amino group}

Selective protection of the amino group before ring-closure is facile, thus it is the most common way to synthesize aziridines from amino alcohols. The acid lability of $\mathrm{N}$-H vinylaziridines limits the number of useful activating groups, as the conditions needed for deprotection of several activating groups are expected to destroy the aziridine moiety. ${ }^{88}$

\section{Tritylation}

Our first choice was the triphenylmethyl (trityl) group, which had been successfully employed in aziridination reactions. ${ }^{89}$ Furthermore mild, although acidic, conditions were used for deprotection. Tritylation of $\mathbf{2 a}$ proceeded almost quantatively (Scheme 22), ${ }^{90}$ and with trityl amino alcohol 14 in hand, several ring-closing methods could be utilized. The Mitsunobu protocol described above afforded tritylaziridine $\mathbf{1 5}$ in $99 \%$ yield.

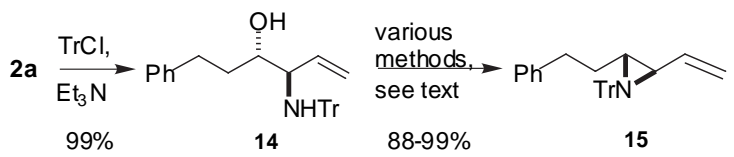

Scheme 22: Amino group activation prior to ring-closure.

Alternatively, the hydroxy group in $\mathbf{1 4}$ could be mesylated to provide compound $\mathbf{C}$ (Scheme 23). This derivative was conveniently ring-closed to yield $\mathbf{1 5}$ at elevated temperature. ${ }^{91}$ With 1.0 equiv $\mathrm{MsCl}$, tritylaziridine $\mathbf{1 5}$ was formed

\footnotetext{
${ }^{88}$ Greene, T. W.; Wuts, P. G. M. Protective Groups in Organic Synthesis; 3rd ed.; Wiley: New York, 1999.

${ }^{89}$ Kuyl-Yeheskiely, E.; Lodder, M.; van der Marel, G. A.; van Boom, J. H. Tetrahedron Lett. 1992, 33, 3013-3016.

${ }^{90}$ Evans, P. A.; Holmes, A. B.; Russell, K. J. Chem. Soc., Perkin Trans. 1 1994, 3397-3409.

${ }^{91}$ Willems, J. G. H.; Hersmis, M. C.; de Gelder, R.; Smits, J. M. M.; Hammink, J. B.; Dommerholt, F. J.; Thijs, L.; Zwanenburg, B. J. Chem. Soc., Perkin Trans. 1 1997, 963-967.
} 
in $88 \%$ yield together with $12 \%$ recovered 14 . When an excess of $\mathrm{MsCl}(1.25$ equiv) was employed, $\mathbf{1 5}$ was formed along with unidentified byproducts.

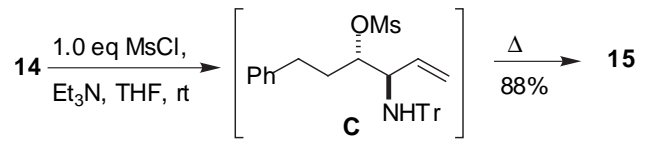

Scheme 23: Synthesis of 15 by mesylation and ring-closure.

A third possibility employed cyclic sulfamidate $\mathbf{1 6}$ (Scheme 24), formed by reaction between $\mathbf{1 4}$ and sulfuryl chloride. In situ conversion of this type of derivative to the corresponding aziridine was reported to proceed at $\mathrm{rt}^{89}$

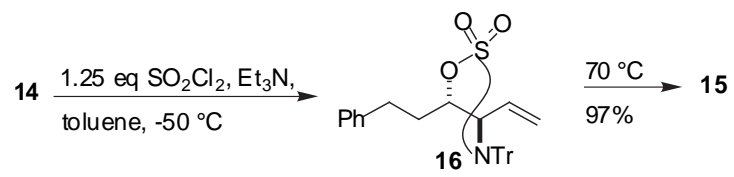

Scheme 24: Ring-closure of $\mathbf{1 4}$ via cyclic sulfamidate $\mathbf{1 6}$.

When trityl amino alcohol $\mathbf{1 4}$ was treated with surfuryl chloride, sulfamidate $\mathbf{1 6}$ was indeed formed, but ring-closure to aziridine $\mathbf{1 5}$ did not take place at $\mathrm{rt}$. Attempted purification by flash chromatography converted $\mathbf{1 6}$ to the desired aziridine 15 in $60 \%$ yield. The conversion could instead be performed in excellent yield by heating the reaction mixture to $70{ }^{\circ} \mathrm{C}$ for $1 \mathrm{~h}$.

Removal of the trityl group to $\mathrm{N}$-H aziridine $4 \mathbf{a}$ was the most difficult part of the sequence, as $\mathrm{N}-\mathrm{H}$ vinylaziridines are acid labile (Scheme 25). Treatment with TFA and water as a trityl scavenger furnished $\mathbf{4 a}$ in $79 \%$ yield. ${ }^{9293}$ Formic acid in methanol worked equally well, ${ }^{94}$ whereas the combination of TFA and methanol gave only decomposition products..$^{95}$ A recently published reductive detritylation, developed especially for sensitive aziridines, was also employed. ${ }^{96}$ Disappointingly this reaction, utilizing TFA and $\mathrm{Et}_{3} \mathrm{SiH}$, proved inferior to the original TFA reaction.

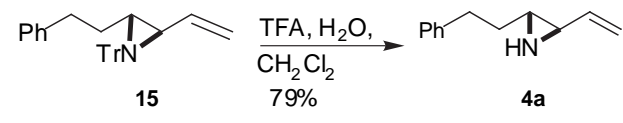

Scheme 25: Detritylation of 15.

Thus, the three-step transformation of amino alcohol 2a into aziridine $4 \mathbf{a}$ was achieved in $77 \%$ via Mitsunobu cyclization, in $69 \%$ via mesylation and in $76 \%$ via the cyclic sulfamidate.

\footnotetext{
${ }^{92}$ Alsina, J.; Giralt, E.; Albericio, F. Tetrahedron Lett. 1996, 37, 4195-4198.

93 The optimal reaction temperature was $-10{ }^{\circ} \mathrm{C}$; reaction at $\mathrm{rt}$ gave $4 \mathrm{a}$ in moderate yield whereas lower temperature effected no reaction.

${ }^{94}$ Bosche, U.; Nubbemeyer, U. Tetrahedron 1999, 55, 6883-6904.

${ }^{95}$ Church, N. J.; Young, D. W. J. Chem. Soc., Perkin Trans. 1 1998, 1475-1482.

${ }^{96}$ Vedejs, E.; Klapars, A.; Warner, D. L.; Weiss, A. H. J. Org. Chem. 2001, 66, 7542-7546.
} 


\section{Nosylation}

In a similar reaction sequence, the 2,4-dinitrobenzenesulfonyl group was utilized (Scheme 26). ${ }^{97}$ Although both protection to 17 and ring-closure to 18 were fast reactions, the yields were poor compared to the tritylation sequence. Furthermore, attempted deprotection of $\mathbf{1 8}$ to aziridine $\mathbf{4 a}$ was unsuccessful, instead affording the ring-opened diamine 19. ${ }^{98}$

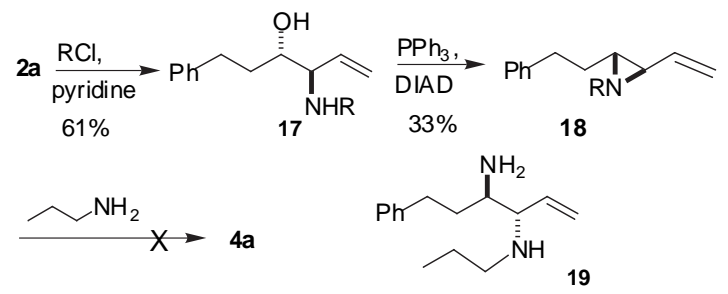

Scheme 26: Nosylation strategy, $R=2,4-$ dinitrobenzenesulfonyl.

To summarize the results of this investigation, direct ring-closure under Mitsunobu conditions proved superior to other methods employed for smallscale reactions, as $\mathrm{N}-\mathrm{H}$ aziridine 4 a was formed in $80 \%$ yield. This should be compared to $74 \%$ via sulfate ester 13 and $69-77 \%$ via tritylation of the amino group. For large-scale reactions, the convenience of easy purification could make the sulfate ester route preferable. Although the same advantage is achieved by the use of polymer bound triphenylphosphine in the Mitsunobu reaction, this reagent does not give complete conversion of all substrates (vide infra). Furthermore, the choice of strategy is substrate depending, as the substituents on the vinylaziridine influence both the polarity (and hence the ease of purification) and the stability on silica gel.

\subsection{Synthesis of vinylaziridines $4 \mathrm{~b}-\mathrm{f}$}

As vinylaziridines $\mathbf{4 b - f}$ were prepared before or in parallel to the investigation described above, only the Mitsunobu conditions were employed in the transformation (Scheme 27). Anti-amino alcohols 2 could be ring-closed into vinylaziridines $\mathbf{4}$ in yields ranging from $80 \%$ for $\mathbf{4 a}$ down to $30 \%$ for $\mathbf{4 b}$ (Table 7). The poor yield of $\mathbf{4 b}$ could be increased to $72 \%$ by careful purification on deactivated silica, indicating that the purification might be more important than the reaction conditions for certain substrates (entry 2).

\footnotetext{
${ }^{97}$ Fukuyama, T.; Cheung, M.; Jow, C. K.; Hidai, Y.; Kan, T. Tetrahedron Lett. 1997, 38, 5831-5834. ()Farràs, J.; Ginesta, X.; Sutton, P. W.; Taltavull, J.; Egeler, F.; Romea, P.; Urpí, F.; Vilarrasa, J. Tetrahedron 2001, 57, 7665-7674.

${ }^{98}$ Deprotection with mercaptoacetic acid was not attempted.
} 


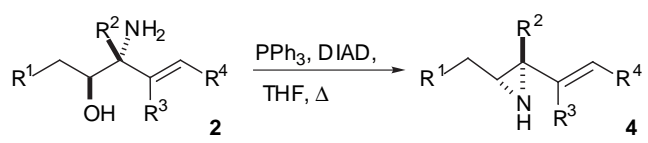

Scheme 27: Synthesis of vinylaziridines 4 .

Aziridine 4c was formed in $93 \%$ crude yield according to integration on NMR, but due to its instability even on deactivated silica the isolated yield was poor. This could partially be circumvented by using polymer bound $\mathrm{PPh}_{3}$, which gave an easily purified crude product but decreased reaction rate. With this protocol, aziridine $\mathbf{4 c}$ could be isolated in $78 \%$ yield based on recovered starting material (entry 3). Surprisingly, aziridine 4d coevaporated with EtOAc, which made purification troublesome as other solvent systems diminished the silica deactivation and gave unpure aziridine (entry 4). ${ }^{99}$

Table 7. Synthesis of aziridines 4 .

\begin{tabular}{ccccccc}
\hline Entry & Substrate & $\mathbf{R}^{\mathbf{1}}$ & $\mathbf{R}^{\mathbf{2}}$ & $\mathbf{R}^{\mathbf{3}}$ & $\mathbf{R}^{\mathbf{4}}$ & Yield of 4 (\%) $^{\mathrm{a}}$ \\
\hline 1 & $\mathbf{2 a}$ & $\mathrm{PhCH}_{2}$ & $\mathrm{H}$ & $\mathrm{H}$ & $\mathrm{H}$ & 80 \\
2 & $\mathbf{2 b}$ & $\mathrm{BnO}$ & $\mathrm{H}$ & $\mathrm{H}$ & $\mathrm{H}$ & 72 \\
3 & $\mathbf{2 c}$ & $\mathrm{BnO}$ & $\mathrm{H}$ & $\mathrm{H}$ & $\mathrm{CH}_{2} \mathrm{OPMB}$ & $60^{\mathrm{b}}$ \\
4 & $\mathbf{2 d}$ & $\mathrm{H}$ & $\mathrm{H}$ & $\mathrm{H}$ & $\mathrm{CH}_{2} \mathrm{OBn}$ & $62^{\mathrm{c}}$ \\
5 & $\mathbf{2 e}$ & $\mathrm{Me}$ & $\mathrm{Me}$ & $\mathrm{H}$ & $\mathrm{CH}_{2} \mathrm{OBn}$ & $80^{\mathrm{d}}$ \\
6 & $\mathbf{2 f}$ & $\mathrm{PMBO}$ & $\mathrm{H}$ & $\mathrm{CH}_{2} \mathrm{OBn}$ & $\mathrm{H}$ & 63 \\
\hline
\end{tabular}

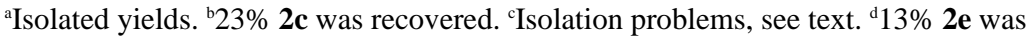
recovered.

Syntheses of trisubstituted $\mathrm{N}-\mathrm{H}$ aziridines are rare and described yields are moderate. ${ }^{100}$ This may be due to difficulties both in forming precursors as $\mathbf{2 e}$ and in subsequent ring-closure to aziridines, the reaction rates being retarded by sterical hindrance.

To our delight, ring-closure of $\mathbf{2} \mathbf{e}$ to trisubstituted aziridine $\mathbf{4} \mathbf{e}$ under Mitsunobu conditions proceeded smoothly. Although the reaction stopped before full conversion, ${ }^{101}$ this substrate surprisingly gave the best results to date in the ring-closure. The methyl substituent rendered $\mathbf{4 e}$ relatively unpolar, which simplified the purification and $\mathbf{4 e}$ could be isolated in $80 \%$ yield with remaining 2e readily recovered (entry 5). The yield based on recovered $2 \mathbf{e}$ was thus an excellent $92 \%$.

\footnotetext{
${ }^{99}$ Careful removal of EtOAc by distillation from a $-78^{\circ} \mathrm{C}$ cooling bath gave loss of product whereas high-vacuum on the isolated compound did not result in losses.

${ }^{100}$ (a) Viallon, L.; Reinaud, O.; Capdevielle, P.; Maumy, M. Tetrahedron 1996, 52, 13505-13614. (b) Wipf, P.; Henninger, T. C.; Geib, S. J. J. Org. Chem. 1998, 63, 6088-6089.

${ }^{101}$ Optimization attempts failed; neither prolonged reaction time nor large excess of reagents improved the conversion, instead a byproduct was formed.
} 
When regioisomeric mixtures of amino alcohols $\mathbf{2}$ and $\mathbf{5}$ were obtained in the aminolysis (see Chapter 3), separation of the isomers was needless as ringclosure of both species resulted in aziridines 4 . Surprisingly, the mixture of $\mathbf{2 e}$ and $\mathbf{5 e}$, obtained by aminolysis of $\mathbf{1 e}$, could also be ring-closed to $\mathbf{4 e}$ in good yield despite the sterical hindrance in $\mathbf{5 e}$. 


\section{Solvolysis of Vinylaziridines 4 to anti-Amino Alcohols 5}

(Papers II-IV)

6

\subsection{Introduction}

Ring-opening of activated aziridines ${ }^{102}$ has recently become a field of major interest. Yadav and Singh have focused on Lewis acid-catalyzed ring-openings of $N$-tosyl aziridines with various amines, alcohols and carboxylic acids. ${ }^{103,104,105}$ The nucleophilic attack normally takes place on the least hindered carbon atom with moderate regioselectivity, the exception being aryl-substituted aziridines that are regioselectively ring-opened in the benzylic position.

Hydrolysis of activated aziridines mediated by Brønstedt acids normally proceeds with rather poor regioselectivity. ${ }^{19,106,107}$ Ibuka has employed organocopper reagents to obtain $\mathrm{S}_{\mathrm{N}} 2$ ' addition to vinylaziridines. ${ }^{108}$ There are no reports on hydrolysis of $N-\mathrm{H}$ aziridines, which may be due both to the low reactivity of unactivated aziridines and to the difficulty of synthesizing $N-\mathrm{H}$ aziridines. ${ }^{83}$

\footnotetext{
${ }^{102}$ Ibuka, T.; Nakai, K.; Habashita, H.; Hotta, Y.; Otaka, A.; Tamamura, H.; Fujii, N. J. Org. Chem. 1995, 60, 2044-2058.

${ }^{103}$ Yadav, J. S.; Reddy, B. V. S.; Jyothirmai, B.; Murty, M. S. R. Synlett 2002, 53-56.

${ }^{104}$ Yadav, J. S.; Reddy, B. V. S.; Abraham, S.; Sabitha, G. Tetrahedron Lett. 2002, 43, 1565-1567.

${ }^{105}$ Prasad, B. A. B.; Sanghi, R.; Singh, V. K. Tetrahedron 2002, 58, 7355-7363.

${ }^{106}$ Prasad, B. A. B.; Sekar, G.; Singh, V. K. Tetrahedron Lett. 2000, 41, 4677-4679.

${ }^{107}$ Tamamura, H.; Yamashita, M.; Nakajima, Y.; Sakano, K.; Otaka, A.; Ohno, H.; Ibuka, T.; Fujii, N. J. Chem. Soc., Perkin Trans. 1 1999, 2983-2996.

${ }^{108}$ Toda, A.; Aoyama, H.; Mimura, N.; Ohno, H.; Fujii, N.; Ibuka, T. J. Org. Chem. 1998, 63, 70537061.
} 


\subsection{Solvolysis of vinylaziridines 4}

Anticipating that the vinyl moiety would activate the aziridine towards ringopening, we set out to find suitable conditions for a Brønstedt acid-mediated solvolysis reaction. As the aziridine becomes protonated, the allylic bond weakens and ring-opening becomes facilitated. To elude loss of diastereoselectivity, the formation of a carbocation must be avoided. Furthermore, the amine nitrogen is more basic than the aziridine nitrogen, which renders the use of a catalytic amount of acid difficult.

To our delight, $N$-H vinylaziridines 4 could be hydrolyzed into anti-amino alcohols 5 (Scheme 28) under acidic conditions. Initial hydrolysis attempts with $4 \mathbf{a}$ were performed with a catalytic amount of tosic acid in $\mathrm{THF} / \mathrm{H}_{2} \mathrm{O}$, which indeed resulted in a catalytic amount of 5a. When a stoichiometric amount of TsOH was utilized, 5a was obtained as a 9:1 regioisomeric mixture in moderate yield. This result could be improved with perchloric acid, furnishing 5a with complete regioselectivity $(>20: 1)$ in $80 \%$ yield (Table 8 , entry 1$).{ }^{109}$

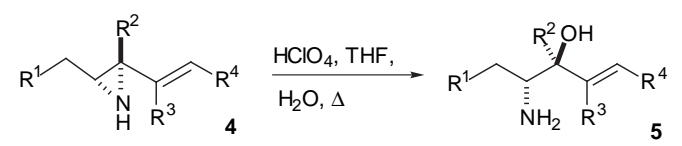

Scheme 28: Solvolysis of vinylaziridines 4 .

When aziridines $\mathbf{4 b - d , f}$ were treated with perchloric acid, anti-amino alcohols 5b-d,f were obtained in good yields (Table 8). The reaction proceeded, as expected, with clean $S_{N} 2$ inversion for substrates 4a-c, f. Surprisingly, amino alcohol 5d was formed in a 10:1 diastereomeric ratio (entry 4), the reason for which is unclear.

Table 8. Synthesis of anti-amino alcohols $\mathbf{5}$.

\begin{tabular}{ccccccc}
\hline Entry & Substrate & $\mathbf{R}^{\mathbf{1}}$ & $\mathbf{R}^{\mathbf{2}}$ & $\mathbf{R}^{\mathbf{3}}$ & $\mathbf{R}^{\mathbf{4}}$ & Yield of 5 (\%) $^{\mathrm{a}}$ \\
\hline 1 & $\mathbf{4 a}$ & $\mathrm{PhCH}_{2}$ & $\mathrm{H}$ & $\mathrm{H}$ & $\mathrm{H}$ & 80 \\
2 & $\mathbf{4 b}$ & $\mathrm{BnO}$ & $\mathrm{H}$ & $\mathrm{H}$ & $\mathrm{H}$ & 84 \\
3 & $\mathbf{4 c}$ & $\mathrm{BnO}$ & $\mathrm{H}$ & $\mathrm{H}$ & $\mathrm{CH}_{2} \mathrm{OPMB}$ & 82 \\
4 & $\mathbf{4 d}$ & $\mathrm{H}$ & $\mathrm{H}$ & $\mathrm{H}$ & $\mathrm{CH}_{2} \mathrm{OBn}$ & $74^{\mathrm{b}}$ \\
5 & $\mathbf{4 e}$ & $\mathrm{Me}$ & $\mathrm{Me}$ & $\mathrm{H}$ & $\mathrm{CH}_{2} \mathrm{OBn}$ & $67^{\mathrm{c}}$ \\
6 & $\mathbf{4 f}$ & $\mathrm{PMBO}$ & $\mathrm{H}$ & $\mathrm{CH}_{2} \mathrm{OBn}$ & $\mathrm{H}$ & 71 \\
\hline
\end{tabular}

asolated yields. ${ }^{\mathrm{b}} d r$ 10:1. ${ }^{\mathrm{c}}$ The reaction was performed with $\mathrm{BF}_{3} \cdot \mathrm{OEt}_{2}, d r$ 2.5:1.

Due to the methyl group situated at the allylic position, we were expecting trisubstituted vinylaziridine $4 \mathbf{e}$ to behave differently than 4a-d,f under acidic conditions. Indeed, amino alcohol 5e was formed in a 1:1 diastereomeric mixture with 6e (Table 9, entry 1) and optimization attempts with perchloric acid failed. The lack of selectivity could be explained by the stabilizing effect of the methyl group on a carbocation intermediate.

${ }^{109}$ Catalytic conditions failed also with perchloric acid. 
Table 9. Solvolysis of $4 \mathbf{e}$ in $\mathrm{THF} / \mathrm{H}_{2} \mathrm{O}$.

\begin{tabular}{clclc} 
Entry & Acid & Equiv & Conditions & Ratio 5e:6e \\
\hline 1 & $\mathrm{HClO}_{4}$ & 1 & $\mathrm{rt}$ & $1: 1$ \\
2 & $\mathrm{LiClO}_{4}$ & 1 & $\mathrm{reflux}$ & $1: 1.4$ \\
3 & $\mathrm{InCl}_{3}$ & 0.1 & $\mathrm{rt}, \mathrm{pH} 4$ & $1: 2.1$ \\
4 & $\mathrm{BF}_{3} \cdot \mathrm{OEt}_{2}$ & 2 & $\mathrm{rt}$ & $2.5: 1$ \\
5 & $\mathrm{BF}_{3} \cdot \mathrm{OEt}_{2}$ & 2 & $-20{ }^{\circ} \mathrm{C} \rightarrow 0{ }^{\circ} \mathrm{C}$ & no reaction \\
6 & $\mathrm{BF}_{3} \cdot \mathrm{OEt}_{2}$ & 0.2 & $\mathrm{rt} \rightarrow$ reflux & $1.3: 1$ \\
7 & $\mathrm{BBr}_{3}$ & 2 & $\mathrm{rt}$ & see text \\
\hline
\end{tabular}

Turning to Lewis acids, we hoped that the carbocation formation would be retarded and the diastereoselectivity thus enhanced. However, $\mathrm{LiClO}_{4}$, which had been reported to mediate similar transformations, was ineffective for this reaction at $\mathrm{rt}$. At reflux temperature, a poor yield of a 1:1.4 mixture of $5 \mathbf{e}$ and $\mathbf{6 e}$ was obtained (entry 2). ${ }^{103,110} \mathrm{InCl}_{3}$ at $\mathrm{pH} 4$ gave a 1:2 mixture of $\mathbf{5 e}$ and $\mathbf{6 e}$, i.e. the unwanted diastereomer was again the major product (entry 3 ). This might be explained by internal delivery of water from $\operatorname{In}\left(\mathrm{H}_{2} \mathrm{O}\right)_{6}{ }^{3+}$ coordinated to nitrogen. ${ }^{104,111}$ Fortunately, employment of 2 equiv $\mathrm{BF}_{3} \cdot \mathrm{OEt}_{2}$ in $\mathrm{THF} / \mathrm{H}_{2} \mathrm{O}$ 10:1 yielded 5e in a 2.5:1 ratio (entry 4). ${ }^{106}$ Reducing the temperature or the amount of acid did not improve this result (entries 5, 6). When $4 \mathbf{e}$ was treated with $\mathrm{BBr}_{3}$ no product was isolated, instead partly epimerized $4 \mathbf{e}$ could be recovered (entry 7).

${ }^{110}$ Parrodi, C. A.; Vazquez, V.; Quintero, L.; Juraristi, E. Synth. Commun. 2001, 31, 3295-3302.

${ }^{111}$ Fringuelli, F.; Pizzo, F.; Vaccaro, L. J. Org. Chem. 2001, 66, 3554-3558. 


\title{
Aziridine Rearrangement leading to syn-Amino Alcohols 6
}

(Papers II-IV)

Regioselective ring-opening of aziridines $\mathbf{4}$ with retention of configuration would yield syn-amino alcohols $\mathbf{6}$ (see Scheme 12). This can be achieved either by a reaction proceeding with double inversion or by an intramolecular rearrangement. The Lewis acid-catalyzed rearrangement of acylaziridines into the corresponding oxazolines is reported to proceed with an $\mathrm{S}_{\mathrm{N}} \mathrm{i}$ mechanism to give retention of stereochemistry, as outlined in Scheme 29. ${ }^{112}$ The Lewis acid coordinates to the aziridine nitrogen, which is more basic than the carbonyl oxygen, and weakens the $\mathrm{C} 2-\mathrm{N}$ bond. $\mathrm{C} 2$ is then attacked by the carbonyl oxygen in a front-side manner, giving the corresponding oxazoline with retention of configuration. The regioselectivity observed in the two cases reported $\left(\mathrm{R}^{1}=\mathrm{H}\right.$ and $\mathrm{R}^{2}=\mathrm{Me}$ or $\mathrm{Ph}$ ) can be explained by a partial positive charge on $\mathrm{C} 2$ being more stabilized than on $\mathrm{C} 3$. When both $\mathrm{R}^{1}$ and $\mathrm{R}^{2}$ are alkyl groups, the regioselectivity may become problematic. Brønstedt acids can also be used to effect the reaction, although the mechanism in these cases might be different.
\end{abstract}
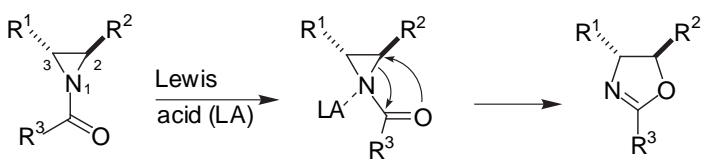

Scheme 29: Rearrangement of acylaziridine with $\mathrm{S}_{\mathrm{N}} \mathrm{i}$ mechanism.

Applying this reaction to vinylaziridines 4 , the reaction sequence leading from 4 to $s y n$-amino alcohols $\mathbf{6}$ is depicted in Scheme 30.

${ }^{112}$ Hori, K.; Nishiguchi, T.; Nabeya, A. J. Org. Chem. 1997, 62, 3081-3088. 


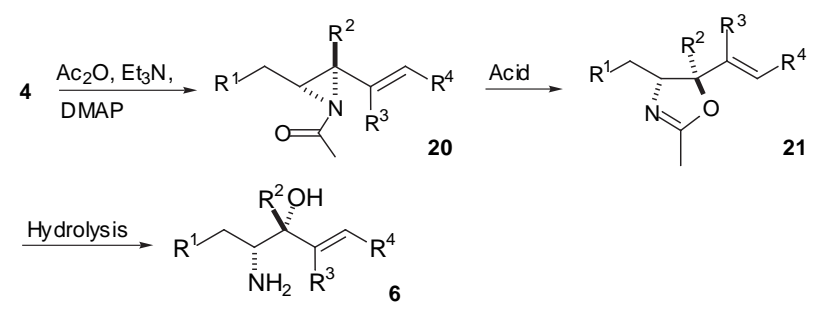

Scheme 30: Transformation of $\mathbf{4}$ to syn-amino alcohols 6 .

\subsection{Acetylation}

Acetylation of aziridines $\mathbf{4 a - d}, \mathbf{f}$ proceeded with nearly quantitative yields under standard conditions $\left(\mathrm{Ac}_{2} \mathrm{O}, \mathrm{Et}_{3} \mathrm{~N}, 0.05\right.$ equiv DMAP). As $\mathrm{N}$-acetylaziridines are unstable on silica gel, ${ }^{113}$ compounds 20a-d, $\mathbf{f}$ were used as crude products in the subsequent rearrangement.

The acetylation of trisubstituted aziridine $4 \mathbf{e}$ was troublesome, affording a mixture of 20e and an unidentified byproduct. ${ }^{114}$ When $4 \mathbf{e}$ was treated with $\mathrm{Ac}_{2} \mathrm{O}$ and $\mathrm{Et}_{3} \mathrm{~N}$ without DMAP catalysis, the reaction rate was considerably lower and solely byproduct was formed. When the acetyl source was changed to $\mathrm{AcCl}$, the reaction was instant, yet only the same byproduct was formed. ${ }^{115}$ The byproduct formation could be diminished by addition of a large excess of $\mathrm{Et}_{3} \mathrm{~N}$ (20 equiv) under DMAP catalysis. Surprisingly, clean acetylation could be acheived with $\mathrm{Ac}_{2} \mathrm{O}$ and a stoichiometric amount of DMAP. At this point only the removal of DMAP remained problematic; acidic workup or flash chromatography destroyed the product, whereas remains of DMAP in the crude product would interfere in the rearrangement. Luckily, the acetylation proceeded equally well with polymer bound DMAP.

\subsection{Rearrangement}

Several methods reported to cause the rearrangement to oxazolines $\mathbf{2 1}$ were scanned with $N$-acetylaziridine 20 a (Scheme $30, \mathrm{R}^{1}=\mathrm{PhCH}_{2}, \mathrm{R}^{2}, \mathrm{R}^{3}, \mathrm{R}^{4}=\mathrm{H}$ ). Reflux in chloroform was unsuccessful ${ }^{116}$ and $\mathrm{TsOH} \cdot \mathrm{H}_{2} \mathrm{O}$ in toluene instead afforded hydroxyamide 22a (Figure 8a) in moderate yield, with minor amounts of 21 a. ${ }^{17}$ Early attempts with sodium iodide gave oxazoline 21 a a

\footnotetext{
${ }^{113}$ Lindström, U. M.; Somfai, P. J. Am. Chem. Soc. 1997, 119, 8385-8386.

114 The ratio of byproduct was independent of the reaction time, suggesting that it was formed from 4e rather than from $20 \mathrm{e}$.

115 This indicates that although the anion might take part in the reaction, is not present in the byproduct.

${ }^{116}$ Cardillo, G.; Gentilucci, L.; Tolomelli, A.; Tomasini, C. Tetrahedron Lett. 1997, 38, 6953-6956.

${ }^{117}$ Nishiguchi, T.; Tochio, H.; Nabeya, A.; Iwakura, Y. J. Am. Chem. Soc. 1968, 91, 5835-5845.
} 
diastereomeric mixture, ${ }^{118}$ but fine-tuning of the reaction conditions caused a slow but clean rearrangement to 21a. ${ }^{119}$ Turning to Lewis acids, copper triflate caused a slow rearrangement to $\mathbf{2 1 a}{ }^{120}$ Treatment with $\mathrm{BF}_{3} \cdot \mathrm{OEt}_{2}{ }^{112}$ in toluene resulted in a mixture of oxazoline $\mathbf{2 1}$ a and ring-closed byproduct $\mathbf{2 3}$, the formation of which could be suppressed by lowering the temperature (Figure $8 b) .{ }^{121}$<smiles>C=CC(O)C(CCc1ccccc1)NC(C)=O</smiles>

Figure 8. a) Hydroxyamide 22a. b) Ring-closed byproduct 23.

\subsubsection{In situ hydrolysis}

Despite the clean rearrangement with $\mathrm{BF}_{3} \cdot \mathrm{OEt}_{2}$, oxazoline 21a could only be isolated in $55 \%$ yield. Unexpectedly, 21 a was partly hydrolyzed during purification, furnishing a mixture of 21a and hydroxyamide 22a after flash chromatography. ${ }^{88,122}$ To avoid this loss, we turned our attention to a two step, one pot formation of 22a from 20a (Scheme 31). Returning to the $\mathrm{TsOH} \cdot \mathrm{H}_{2} \mathrm{O}$ mediated reaction (vide supra), the results indicated initial formation of $\mathbf{2 1 a}$ followed by partial hydrolysis to 22a. Indeed, treatment of oxazoline 21a with $\mathrm{TsOH} \cdot \mathrm{H}_{2} \mathrm{O}$ afforded 22a in high yield. Apparently, water caused byproduct formation when present during the rearrangement, ${ }^{123}$ but seemed necessary for the reaction to proceed, as rearrangement was retarded with anhydrous $\mathrm{TsOH}$ or camphorsulfonic acid.

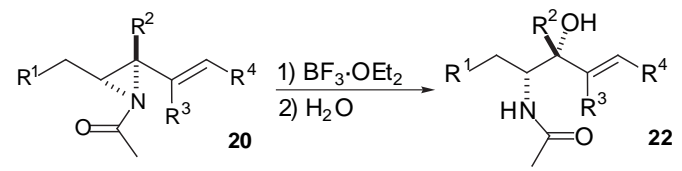

Scheme 31. Rearrangement and in situ hydrolysis to hydroxyamides 22.

As Brønstedt acids seemed ineffective for the hydrolysis to 22, we speculated whether in situ hydrolysis of 21a to $22 \mathrm{a}$ would be possible also in the $\mathrm{BF}_{3} \cdot \mathrm{OEt}_{2}$ rearrangement. After complete formation of $21 \mathbf{a}$ in toluene, water was added to the reaction mixture, which indeed caused slow formation of hydroxyamide 22a along with byproducts (Scheme 31). A change of solvent to THF considerably

\footnotetext{
${ }^{118}$ Foglia, T. A.; Gregory, L. M.; Maerker, G. J. Org. Chem. 1970, 35, 3779-3785.

${ }^{119}$ This reaction proceeds with double inversion of configuration.

${ }^{120}$ Ferraris, D.; Drury, W. J., III; Cox, C.; Lectka, T. J. Org. Chem. 1998, 63, 4568-4569.

${ }^{121}$ Compound 23 is probably the result of a Friedel-Craft's type of ring-opening, see Taylor S. K. et al, Synthesis 1998, 1133-1136 for comparable reactions of epoxides.

${ }^{122}$ Lee, K.-Y.; Kim, Y.-H.; Park, M.-S.; Oh, C.-Y.; Ham, W.-H. J. Org. Chem. 1999, 64, 9450-9458.

${ }^{123}$ The combined yield of 21a and 22a was moderate in the TsOH$\cdot \mathrm{H} 2 \mathrm{O}$-mediated reaction of 20a.
} 
increased the hydrolysis rate, and $22 \mathbf{a}$ could be isolated in $71 \%$ yield from $4 \mathbf{a}$ (Table 10, entry 1 ).

The rearrangement proceeded as expected with complete diastereoselectivity $(d r>20: 1)$, and gratifyingly also with complete regioselectivity (>20:1). The latter could be rationalized by the stabilizing effect of the vinyl group on the transition state, thus favoring an attack of the carbonyl oxygen at the allylic position.

Table 10. Synthesis of syn-amino alcohols 6.

\begin{tabular}{ccccccccc}
\hline Entry & Substrate & $\mathbf{R}^{\mathbf{1}}$ & $\mathbf{R}^{\mathbf{2}}$ & $\mathbf{R}^{\mathbf{3}}$ & $\mathbf{R}^{\mathbf{4}}$ & \multicolumn{2}{c}{ Yield (\%) $^{\mathrm{a}}$} \\
\cline { 4 - 8 } & & & & & & $\mathbf{2 2}$ & $\mathbf{6}$ \\
\hline 1 & $\mathbf{4 a}$ & $\mathrm{PhCH}_{2}$ & $\mathrm{H}$ & $\mathrm{H}$ & $\mathrm{H}$ & 71 & $95^{\mathrm{b}}$ \\
2 & $\mathbf{4 b}$ & $\mathrm{BnO}$ & $\mathrm{H}$ & $\mathrm{H}$ & $\mathrm{H}$ & 73 & $92^{\mathrm{b}}$ \\
3 & $\mathbf{4 c}$ & $\mathrm{BnO}$ & $\mathrm{H}$ & $\mathrm{H}$ & $\mathrm{CH}_{2} \mathrm{OPMB}$ & 73 & $91^{\mathrm{c}}$ \\
4 & $\mathbf{4 d}$ & $\mathrm{H}$ & $\mathrm{H}$ & $\mathrm{H}$ & $\mathrm{CH}_{2} \mathrm{OBn}$ & $74^{\mathrm{d}}$ & $93^{\mathrm{b}}$ \\
5 & $\mathbf{4 e}$ & $\mathrm{Me}$ & $\mathrm{Me}$ & $\mathrm{H}$ & $\mathrm{CH}_{2} \mathrm{OBn}$ & 70 & $-^{\mathrm{e}}$ \\
6 & $\mathbf{4 f}$ & $\mathrm{PMBO}$ & $\mathrm{H}$ & $\mathrm{CH}_{2} \mathrm{OBn}$ & $\mathrm{H}$ & 73 & $84^{\mathrm{c}}$ \\
\hline
\end{tabular}

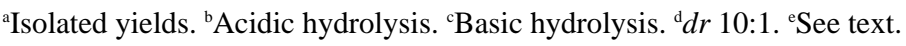

Also acylaziridines 20b-f could be rearranged and hydrolyzed into hydroxyamides $\mathbf{2 2 b}$-f, which were formed in $\geq 70 \%$ yield over two steps (entries 2-6). The diastereoselectivity was complete in all cases apart from 22d (dr 10:1), the reason for which is unclear. ${ }^{124}$

\subsection{Hydrolysis}

Being very stable compounds, amides are normally hydrolyzed with brute force ${ }^{88}$ However, the presence of a vicinal hydroxy group facilitates the reaction considerably ${ }^{88}$ and hydrolysis of hydroxyamides $\mathbf{2 2}$ could be performed under mild conditions. Amides 22a,b were hydrolyzed in $5 \%$ aq $\mathrm{H}_{2} \mathrm{SO}_{4}$, giving synamino alcohols 6a,b in excellent yields (Scheme 32, Table 10). Due to the acid lability of the PMB group, hydroxyamides 22c,f were hydrolyzed in $1 \mathrm{M} \mathrm{KOH}$, which gave a slower reaction (entries 3,6). As expected, the reaction proceeded without alterations of the stereochemistry in all cases.

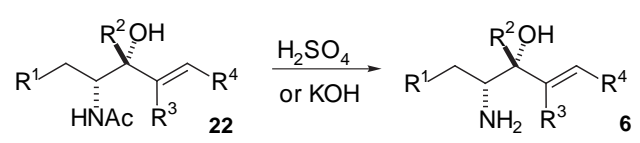

Scheme 32: Hydrolysis of hydroxyamides 22.

Hydrolysis of 22e was severely retarded by sterical hindrance (compare Chapter 4.2). Several reaction conditions were screened without success; acidic

\footnotetext{
${ }^{124}$ Interestingly, when 20e was rearranged with byproduct present (see Chapter 7.1), hydroxyamide 22e was formed as a diastereomeric mixture, the ratio of which depended on the amount of byproduct present in the starting material.
} 
media caused no reaction at $\mathrm{rt}$ and only decomposition at higher temperatures. ${ }^{125}$ Basic media generally caused no reaction, the exceptions being hydrazine, which instead reduced the double bond (see Chapter 9), and $\mathrm{Ca} / \mathrm{NH}_{3}$ that cleaved both amide and benzyl groups. ${ }^{126}$

The different reactivity of regioisomeric hydroxyamide $\mathbf{2 4}$ compared with $\mathbf{2 2 e}$ is noteworthy (Scheme 33). This compound can be hydrolyzed under normal basic conditions, whereas the diastereomeric amide $\mathbf{2 5}$ is as unreactive as amide $22 \mathrm{e}$.<smiles>CCC(N)C(C)(O)/C=C/COCc1ccccc1</smiles>

Scheme 33: Isomeric hydroxyamides 24 and 25 .

\subsubsection{Alternative strategies to reach amino alcohol $6 \mathrm{e}$}

In Evans' asymmetric alkylations, the chiral auxiliary can be removed by $\mathrm{LiOOH}$ treatment, which cleaves the amide bond rather than the oxazolidinone. ${ }^{127}$ As oxazolidinones are easily hydrolyzed to amino alcohols (see Chapter 4.2), this would be a possible strategy towards 6e. Unexpectedly, when 22e was converted to the corresponding acyloxazolidinone $\mathbf{2 6}$ followed by $\mathrm{LiOOH}$ treatment, oxazolidinone 27e was not formed, but amide 22e was recovered (Scheme 34).

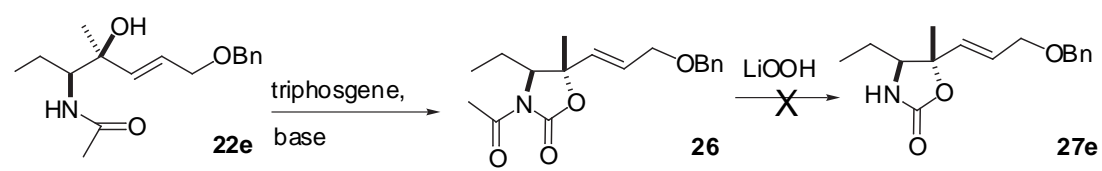

Scheme 34: Hydrolysis attempt via acyloxazolidinone .

Routes avoiding amide 22e were then examined. Oxazoline 21e could be isolated in $89 \%$ yield, ${ }^{128}$ but reduction of this species with $\mathrm{NaBH}_{3} \mathrm{CN}$ in acidic medium to the corresponding oxazolidine $\mathbf{D}$, followed by hydrolysis to $6 \mathbf{e}$ was unsuccessful (Scheme 35). ${ }^{129}$

\footnotetext{
${ }^{125}$ Acidic conditions: $5 \%$ aq $\mathrm{H}_{2} \mathrm{SO}_{4}$, rt to reflux; $5 \% \mathrm{H}_{2} \mathrm{SO}_{4}$ in $\mathrm{THF} / \mathrm{H}_{2} \mathrm{O} 1: 1$, rt to reflux; 5 equiv $\mathrm{BF}_{3} \cdot \mathrm{OEt}_{2}$ in $\mathrm{THF} / \mathrm{H}_{2} \mathrm{O}$ 10:1, rt to reflux; 10 equiv TsOH$\cdot \mathrm{H}_{2} \mathrm{O}$ in THF, rt to reflux.

${ }^{126}$ Basic conditions: $1 \mathrm{M} \mathrm{KOH}$ in EtOH/ $\mathrm{H}_{2} \mathrm{O} 1: 1,150{ }^{\circ} \mathrm{C} ; \mathrm{NH}_{4} \mathrm{OH}$ in $\mathrm{EtOH} / \mathrm{H}_{2} \mathrm{O} 1: 1,140{ }^{\circ} \mathrm{C} ; \mathrm{NH}_{4} \mathrm{OH}$ in $\mathrm{H}_{2} \mathrm{O}$, 50W 15 min; $\mathrm{LiOH}, \mathrm{H}_{2} \mathrm{O}_{2}$ in THF/ $\mathrm{H}_{2} \mathrm{O}$ 3:1, reflux; $\mathrm{NaOEt}$ in EtOH, reflux; $\mathrm{NH}_{2} \mathrm{NH}_{2} \cdot \mathrm{H}_{2} \mathrm{O}$, reflux; $\mathrm{Ca}, \mathrm{NH}_{3}, \mathrm{EtOH}, \mathrm{DME},-30^{\circ} \mathrm{C}$.

${ }^{127}$ Evans, D. A.; Ratz, A. M.; Huff, B. E.; Sheppard, G. S. J. Am. Chem. Soc. 1995, 117, 3448-3467.

${ }^{128}$ This was possible as hydrolysis to $22 \mathrm{e}$ was retarded due to steric hindrance.

${ }^{129}$ Gosmann, G.; Guillaume, D.; Husson, H.-P. Tetrahedron Lett. 1996, 37, 4369-4372.
} 


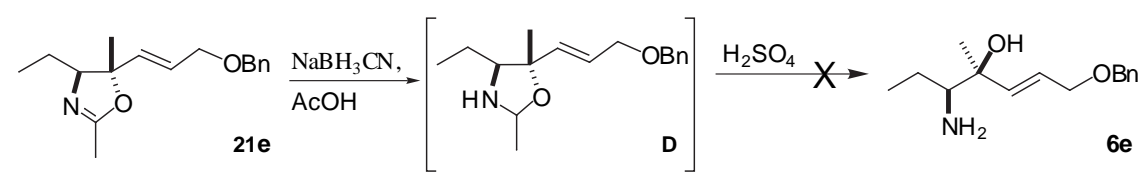

Scheme 35: Reduction of oxazoline 21e.

Instead 6e was obtained via Boc-protection of aziridine $4 \mathbf{e}$ to compound 28 (Scheme 36). ${ }^{130}$ Crude 28 was rearranged with $\mathrm{BF}_{3} \cdot \mathrm{OEt}_{2}$ to oxazolidinone 27e, which was obtained as a separable mixture of diastereomers $(d r 2.3: 1)$ in 66\% combined yield from 4e. Oxazolidinone 27e was easily hydrolyzed with $1 \mathrm{M}$ $\mathrm{KOH}$ to $s y n$-amino alcohol $\mathbf{6 e}$ in $98 \%$ yield.

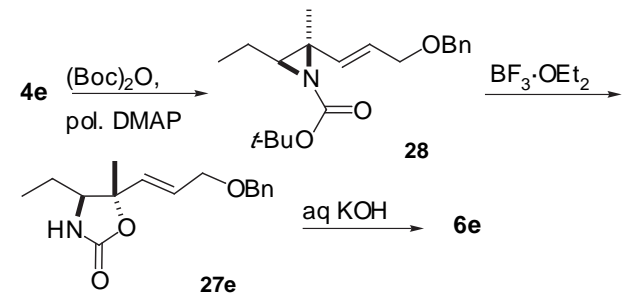

Scheme 36. Rearrangement to oxazolidinone $27 \mathrm{e}$ followed by hydrolysis to $\mathbf{6 e}$.

${ }^{130}$ Sepulveda-Arques, J.; Armero-Alarte, T.; Acero-Alarcon, A.; Zaballos-Garcia, E.; Solesio, B. Y.; Carrera, J. E. Tetrahedron 1996, 52, 2097-2102. 


\section{Synthesis of Sphingosine and its Regio- and Stereoisomers}

(Paper VI)

Having developed the divergent synthesis of vic-amino alcohols described in the previous chapters, we turned our attention to finding a suitable natural product, on which to apply the route. Ideally, not only the compound itself but also its diastereo- and regioisomers should be interesting targets of total synthesis. These demands could be met by D-erythro-sphingosine.

\subsection{Background}

Glycosphingolipids are ubiquitous membrane components of all eucaryotic cells, located in plasma membranes as well as in some intracellular organelles. The backbone of sphingolipids consists of long-chain aliphatic 2-amino-1,3-diols, of which D-erythro-sphingosine is the most common (29, Figure 9). Sphingolipids, as well as sphingosine itself, are important in such diverse biological phenomena as cell-cell-recognition and signaling within and between cells. ${ }^{131}$ Numerous structurally related sphingoid base structures are present in nature, such as phytosphingosines and sphingofungins (Figure 9). The vast distribution of sphingolipids in both plants and animals has led to an immense interest of this compound class in medical research.

${ }^{131}$ (a) Karlsson, K.-A. Trends Pharm. Sci. 1991, 12, 265-272. (b) Liscowitch, M.; Lavie, Y. Trends. Glycosci. Glycothechn. 1990, 2, 470-485. (c) Hannun, Y.; Bell, R. M. Science 1989, 243, 500-507. 


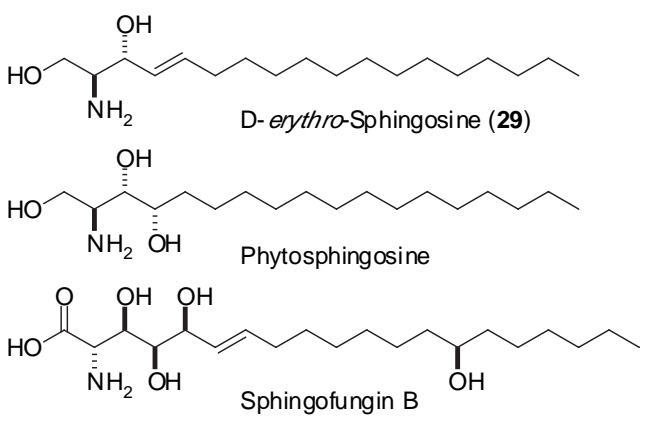

Figure 9. Various sphingoid bases.

Sphingosine and its isomers have been targets of synthetic interest for decades, and well over 50 total syntheses have been published. Most asymmetric syntheses have relied on the chiral pool, starting from sugars or amino acids. Other investigations have made use of asymmetric reactions, often Sharpless asymmetric epoxidation or aldol reactions with a chiral auxiliary, to create the two stereocenters. ${ }^{132}$ Divergent syntheses have been rare, though Hudlicky recently presented an elegant synthesis of sphingosine and its diastereomers. ${ }^{133}$ No divergent route from a common starting material towards all possible regioand stereoisomers of sphingosine has been documented.

Application of our synthesis scheme starting from vinylepoxide $\mathbf{1 l}$ (Scheme 37) would lead to D-erythro-sphingosine (29, Figure 10) and its diastereo- and regioisomers (30-32). The remaining four sphingosine isomers (ent-29 to ent-32) can simply be obtained by starting from vinylepoxide ent-11.

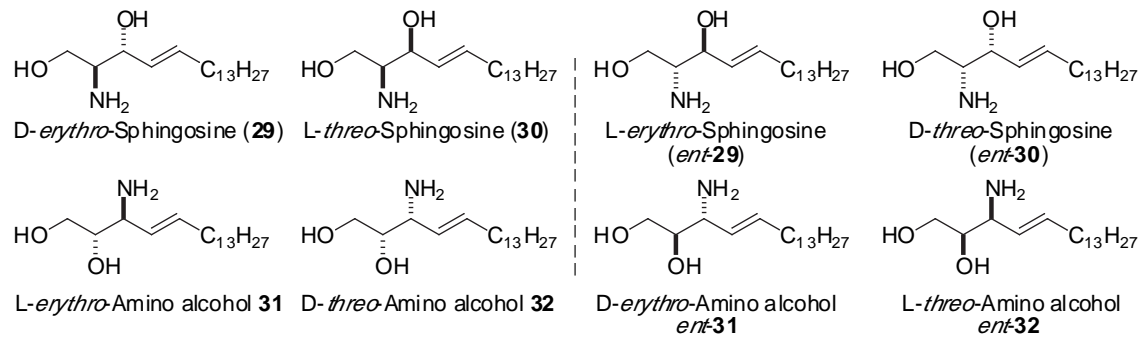

Figure 10. All possible regio- and stereoisomers of sphingosine.

\subsection{Synthesis of vinylepoxide 11}

We envisaged the synthesis to begin with commercially available tetradecanol, which could be transformed into $\mathbf{1 l}$ in four steps (Scheme 37). A Swern/Wittig

${ }^{132}$ Koskinen, P. M.; Koskinen, A. M. P. Synthesis 1998, 1075-1091.

${ }^{133}$ Nugent, T. C.; Hudlicky, T. J. Org. Chem. 1998, 63, 510-520. For other divergent approaches, see Shultz, M. D.; Kiessling, L. L. Abstracts of Papers, 222nd ACS National Meeting, Chicago, IL, United States, August 26-30 2001, ORGN-055 and Lee, J.-M.; Lim, H.-S.; Chung, S.-K. Tetrahedron: Asymmetry 2002, 13, 343-347. 
procedure would give the unsaturated ester 33, which would be reduced to dienol 34. Catalytic Sharpless symmetric epoxidation to epoxyalcohol $\mathbf{3 5}$ could be attempted on this species, although the stoichiometric SAE has been reported to cause decomposition. ${ }^{29}$ Alternatively, $\mathbf{3 4}$ could be benzylated to $\mathbf{3 6}$ prior to epoxidation using Shi's catalyst 7, although this would give rise to two regioisomeric vinylepoxides (1l and $\mathbf{1 m}){ }^{35}$

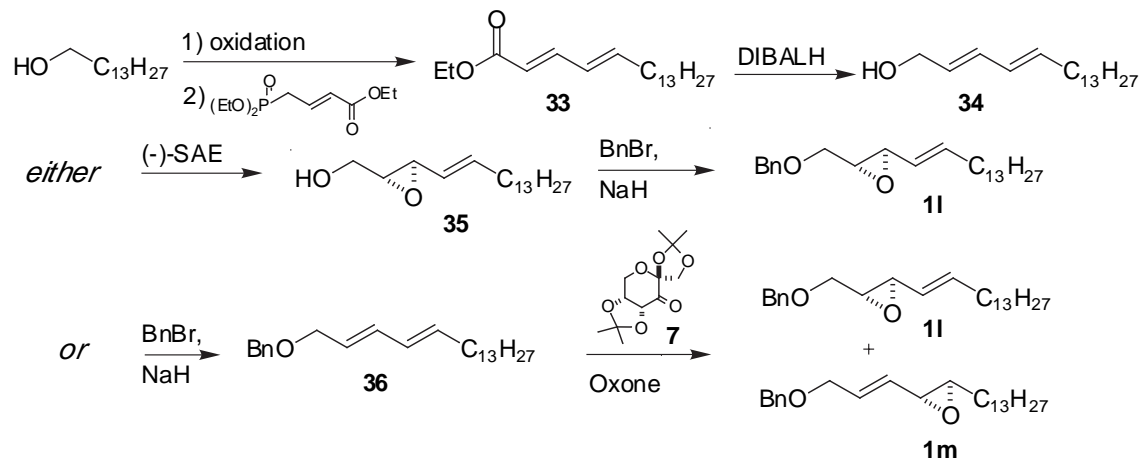

Scheme 37. Synthesis of vinylepoxide 11.

Due to the lipid chain present throughout the reaction scheme, solubility problems were often encountered at low temperatures. Thus, Swern oxidation gave poor yield of the corresponding aldehyde. TPAP ${ }^{134}$ or $\mathrm{IBX}^{135}$ oxidation performed at $\mathrm{rt}$ gave better results. IBX was the method of choice due to simplified workup and thus better yield of the aldehyde, which was used as crude product in the subsequent olefination. In our experience, diene esters like $\mathbf{3 3}$ could be unstable on silica, which rendered the Horner-Emmons procedure a better choice than the classical Wittig reaction. When the reaction was performed with KHMDS (or $\mathrm{NaH}$ ) and triethyl phosphonocrotonate, a complicated mixture of products was obtained. This might be explained by poor solubility at low reaction temperature and too high reactivity upon increased temperature.

To avoid this problem a different approach using $\mathrm{LiOH}$, triethyl phosphonocrotonate and molecular sieves in refluxing THF was attempted. ${ }^{136}$ With this procedure, $\mathbf{3 3}$ was formed in quantitative crude yield and good $E, E$ selectivity. ${ }^{137}$ Crude diene ester 33 could be reduced with DIBALH at $-40{ }^{\circ} \mathrm{C}$ to dienol 34, which was isolated in 59\% yield from tetradecanol.

\footnotetext{
${ }^{134}$ Ley, S. V.; Norman, J.; Griffith, W. P.; Marsden, S. P. Synthesis 1994, 639-666.

${ }^{135}$ For synthesis of IBX see Frigerio, M.; Santagostino, M.; Sputore, S. J. Org. Chem. 1999, 64, 4537-4538. For oxidation with IBX see Frigerio, M.; Santagostino, M.; Sputore, S.; Palmisano, G. $J$. Org. Chem. 1995, 60, 7272-7276.

136 Takacs, J. M.; Jaber, M. R.; Clement, F.; Walters, C. J. Org. Chem. 1998, 63, 6757-6760.

${ }^{137} 10: 1$ ratio ( $E, E$-isomer to other isomers). The ratio could not be improved by iodine isomerization.
} 


\subsubsection{Epoxidation strategies}

Sharpless epoxidation of dienes is often troublesome, as discussed in Chapter 2. Not surprisingly, catalytic SAE of dienol $\mathbf{3 4}$ resulted in a mixture of compounds lacking double bonds, as in the stoichiometric attempt previously reported. ${ }^{29}$ No optimization attempts of the SAE were made; instead we aimed at Shi epoxidation of diene 36 .

Benzylation of $\mathbf{3 4}$ proved more difficult than expected, as the reaction stopped before completion under standard conditions. ${ }^{138}$ As E,E-hexadienol could be benzylated to compound $\mathbf{3 7}$ in $98 \%$ yield (Scheme 38), the lipid chain might be the origin of these problems. Extended reaction time, increased temperature, excess reagents or slow addition of $\mathbf{3 4}$ to avoid possible micelle formation all resulted in no improvement. Other procedures were scanned; both $\mathrm{Ag}_{2} \mathrm{O} / \mathrm{BnBr}^{48}$ (see Chapter 2) and benzyl trichlorotriacetimidate/ triflic acid ${ }^{139}$ gave a complex mixture of products. Finally, addition of $\mathrm{Bu}_{4} \mathrm{NI}$ to the original protocol sufficed to give benzylated diene $\mathbf{3 6}$ in $95 \%$ yield. ${ }^{140}$

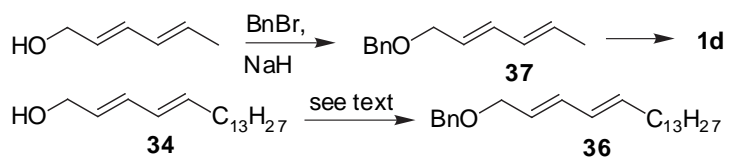

Scheme 38: Benzylation of hexadienol and 34 .

Shi epoxidation works well on protected dienols, epoxidizing the most electron rich double bond with good selectivity. ${ }^{35}$ Epoxidation of diene 37, which differs from 36 only by the length of the carbon chain (Scheme 38), resulted in a 4:1 mixture of regioisomers, favoring reaction at the 4,5-double bond (see Chapter 2). We were thus doubtful whether 11, which is expected to be the minor isomer, could be formed in synthetically useful yields with this method. With diene $\mathbf{3 6}$ at hand, Shi's epoxidation was performed. Surprisingly, epoxides $\mathbf{1 l}$ and 1m were formed in a 1:1 ratio, i.e. with far better selectivity than expected. Again, the difference in reaction outcome could be due to the lipid chain, which might shield the 4,5-double bond.

The conversion was initially poor and could not be improved by longer reaction time or increased temperature. However, the conversion proved dependent on the amount of catalyst used. When a stoichiometric amount of 7 was utilized, both enantioselectivity and yield were enhanced (es 87-95\%). ${ }^{141}$ The catalyst is believed to undergo Bayer-Villiger oxidation in the presence of Oxone, and Shi recently described a method using hydrogen peroxide instead of

\footnotetext{
${ }^{138} \mathrm{BnBr}, \mathrm{NaH}$ in THF or DMF, reflux.

${ }^{139}$ Fleming, I.; Lawrence, N. J. J. Chem. Soc., Perkin Trans. 1 1998, 17, 2679-2686.

${ }^{140}$ Kulkarni, B. A.; Sankaranarayanan, A.; Subbaraman, A. S.; Chattopadhyay, S. Tetrahedron: Asymmetry 1999, 10, 1571-1577.

${ }^{141}$ The catalyst is now commercially available from Lancaster as D-Epoxone, but this material gave low conversion and poor enantioselectivity.
} 
Oxone to avoid this. ${ }^{142}$ However, when used on $\mathbf{3 6}$ these conditions failed to give any reaction.

Vinylepoxides are known to be unstable on silica, ${ }^{35}$ and separation of epoxides 11 and $\mathbf{1 m}$ was possible only at the expense of decreased yield. ${ }^{143}$ To avoid this loss, we aimed at separating the isomers at a later stage in the synthesis (vide infra).

\subsection{Ring-openings of vinylepoxide 11}

\subsubsection{Synthesis of anti-Amino Alcohol 21}

Vinylepoxide 11 was unreactive towards initial aminolysis attempts in $\mathrm{NH}_{4} \mathrm{OH}$ and demanded heating to $170{ }^{\circ} \mathrm{C}$ for any reaction to take place. At these rather severe conditions, an unidentified byproduct was formed along with amino alcohol 2l. As we suspected solubility problems to be the reason for the low reactivity, DMF was utilized as co-solvent. Indeed, this resulted in a lowering of the required reaction temperature to $130{ }^{\circ} \mathrm{C}$; furthermore the byproduct formation was suppressed. Surprisingly, a new byproduct, which might be amino alcohol 38, was instead formed in a minor amount (Scheme 39). ${ }^{144}$ With THF as co-solvent, the reaction proceeded without byproduct formation, giving antiamino alcohol $\mathbf{2 l}$ in $98 \%$ yield with complete regioselectivity (>20:1).

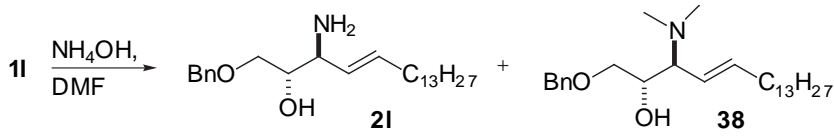

Scheme 39. Aminolysis of $\mathbf{1 l}$ with DMF as co-solvent.

Also vinylepoxide 1m (see Scheme 37) was subjected to aminolysis in ammonium hydroxide. Surprisingly, this compound was even less reactive than 11, which might be explained by the lipid chain being closer to the allylic position than in 11. This finding caused us to investigate whether a mixture of vinylepoxides $\mathbf{1 l}$ and $\mathbf{1} \mathbf{~ m}$ could be used in the aminolysis, with selective formation of $\mathbf{2 l}$. By decreasing the reaction temperature, the reaction could indeed be made selective in $\mathrm{NH}_{4} \mathrm{OH} / \mathrm{THF}$, which meant that separation of vinylepoxides $\mathbf{1 l}$ and $\mathbf{1 m}$ before aminolysis, with subsequent loss of material, could be avoided.

\footnotetext{
${ }^{142}$ Suhu, L.; Shi, Y. Tetrahedron 2001, 57, 5213-5218.

${ }^{143} 90 \%$ combined crude yield, 50\% combined isolated yield.

${ }^{144}$ The presence of $\mathbf{3 8}$ could be explained by partial decomposition of DMF to dimethylamine under basic conditions and heat, see Armarego, W. L. F.; Perrin, D. D. Purification of Laboratory Chemicals; 4th ed.; Butterworth-Heinemann: Oxford, 1996.
} 


\subsubsection{Synthesis of syn-Amino Alcohol 31}

$\operatorname{Pd}(0)$-catalyzed ring-opening of vinylepoxide $\mathbf{1 l}$ in the presence of tosyl isocyanate gave oxazolidinone $\mathbf{1 0 1}$ in $\mathbf{7 5 \%}$ yield (Scheme 40). Detosylation by titration with sodium naphthalide to $\mathbf{1 2 l}$ was slow, and immediate quench caused formation of amino alcohol 39 by basic hydrolysis of unreacted 10l. After 20 min reaction time, $\mathrm{N}$-H oxazolidinone $\mathbf{1 2 l}$ was isolated in $88 \%$ yield. Basic hydrolysis of $\mathbf{1 2 l}$ resulted in syn-amino alcohol $\mathbf{3 l}$ in nearly quantitative yield.

When a mixture of vinylepoxides $\mathbf{1 l}$ and $\mathbf{1 m}$ (see Scheme 37) was used in the reaction sequence, oxazolidinones $\mathbf{1 2 l}$ and $\mathbf{1 2 m}$ could easily be separated without loss in yield. This rendered the separation of $\mathbf{1 l}$ and $\mathbf{1} \mathbf{~ m}$ redundant, as ringopening to amino alcohols $\mathbf{2}$ and $\mathbf{3 1}$ could be performed without interference of $\mathbf{2 m}$ and $\mathbf{3 m}$.

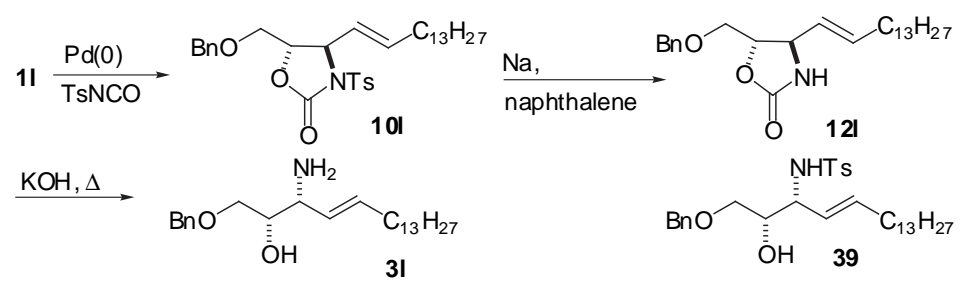

Scheme 40. Ring-opening of $\mathbf{1 l}$ with retention of configuration.

\subsection{Synthesis and ring-openings of vinylaziridine 41}

\subsubsection{Synthesis of Bn-protected D-erythro-Sphingosine 51}

$\mathrm{N}$-H vinylaziridine $\mathbf{4 1}$ was obtained from anti-amino alcohol $\mathbf{2 l}$ by ring-closure under Mitsunobu conditions (Scheme 41). As described in Chapter 5, purification of vinylaziridines is often troublesome due to their instability on silica. As isolation of $\mathbf{4 l}$ resulted in a major loss of product, a mixture of $\mathbf{4 l}$ and reduced DIAD was used in the following reactions. ${ }^{145}$

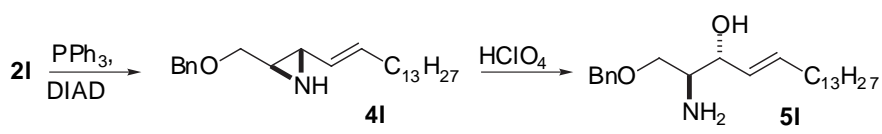

Scheme 41. Formation and ring-opening of vinylaziridine $4 \mathbf{l}$.

When aziridine $4 \mathbf{l}$ was treated with perchloric acid in $\mathrm{THF} / \mathrm{H}_{2} \mathrm{O}$, anti-amino alcohol 5l was surprisingly formed in a 1:1 ratio with 1,4-amino alcohols 40 (Figure 11). Gratefully, when the solvolysis was performed with TFA and $\mathrm{H}_{2} \mathrm{O}$ in $\mathrm{CH}_{2} \mathrm{Cl}_{2}$, the ratio of $\mathbf{5 l}$ to $\mathbf{4 0}$ increased to $3: 1$ and $\mathbf{5 l}$ could be isolated in $62 \%$ yield from 21. The hydrolysis proceeded via amide 41, which was easily hydrolyzed to $\mathbf{5 1}$ under basic conditions.

${ }^{145}$ Because of the unpolar character of $\mathbf{4 l}$, removal of $\mathrm{Ph}_{3} \mathrm{P}=\mathrm{O}$ was easy, whereas reduced DIAD was almost inseparable from $\mathbf{4 l}$. 

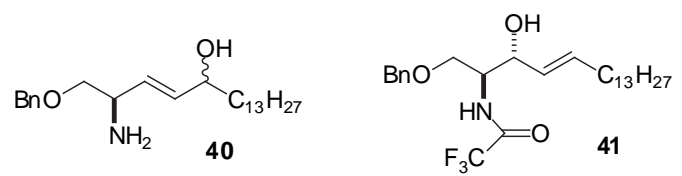

Figure 11. 1,4-amino alcohols 40 and amide 41.

\subsubsection{Synthesis of Bn-protected L-threo-Sphingosine 61}

Acetylation of $\mathbf{4 1}$ proceeded in nearly quantitative yield, and $N$-acetylaziridine 201 was used as crude product in the subsequent reaction (Scheme 42). Rearrangement of $\mathbf{2 0 1}$ was performed with $\mathrm{BF}_{3} \cdot \mathrm{OEt}_{2}$ followed by in situ hydrolysis to hydroxyamide $\mathbf{2 2 1}$, which was isolated in $43 \%$ yield from $\mathbf{2 l}$. The rearrangement proceeded, as expected, with complete diastereo- and regioselectivity (>20:1). Hydroxyamide 221 was hydrolyzed in refluxing $5 \%$ aq $\mathrm{H}_{2} \mathrm{SO}_{4}$, giving syn-amino alcohol $\mathbf{6 l}$ in good yield.

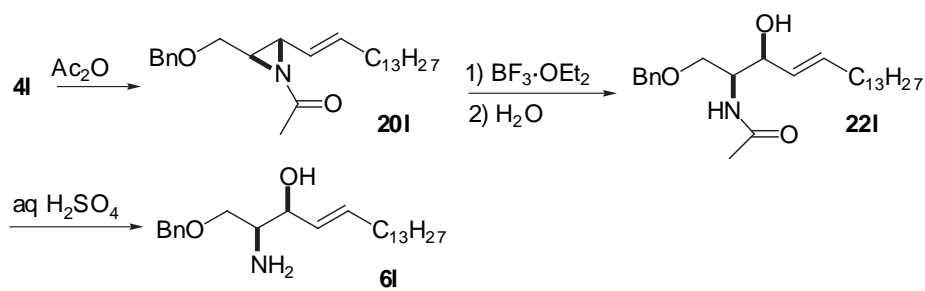

Scheme 42. Ring-opening of $\mathbf{4 l}$ with retention of configuration.

The synthesis was completed by removal of the benzyl group from amino alcohols 2l, $\mathbf{3 l}$ and $\mathbf{5 l}$ (debenzylation of $\mathbf{6 1}$ remains). This was performed by means of sodium in liquid ammonia, giving sphingosine isomers 29, 31 and 32 (see Figure 10) in $91-92 \%$ yield. 


\section{Determination of Regiochemistry and Relative Stereochemistry of vic-Amino Alcohols}

(Papers IV,VII)

9

\subsection{Introduction}

The regiochemistry of vinylic $\beta$-amino alcohols can easily be revealed by ${ }^{1} \mathrm{H}$ NMR, as the allylic proton shifts approximately $0.5 \mathrm{ppm}$ downfield compared with the homoallylic proton. Determination of the relative stereochemistry (syn/anti) is more laborious, demanding complexation or derivatization prior to analysis. Shapiro recently reported an NMR method of determining enantiomeric purity and relative configuration by complexation to (R)-(+)-tbutylphenylphosphinothioic acid, which is not commercially available. ${ }^{146}$ The absolute configuration can be determined by circular dichroism measurements of various amino alcohol-metal complexes. ${ }^{147}$

Most methods to determine configurations of $\beta$-amino alcohols require derivatization before NMR or CD analysis, ${ }^{148}$ e.g. transformation with Mosher's acid. ${ }^{149}$ Several procedures of configurational assignment rely on the rigidity of certain heterocycles. 1,3-Diols can be converted to acetonides, the ${ }^{13} \mathrm{C}-\mathrm{NMR}$

\footnotetext{
${ }^{146}$ Gunderson, K. G.; Shapiro, M. J.; Doti, R. A.; Skiles, J. W. Tetrahedron: Asymmetry 1999, 10, 3263-6266.

${ }^{147}$ See Frelek, J. Tetrahedron: Asymmetry 1999, 10, 2809-2816 and references therein.

${ }^{148}$ Zahn, S.; Canary, J. W. Org. Lett. 1999, 1, 861-864.

${ }^{149}$ Benson, S. C.; Cai, P.; Colon, M.; Haiza, M. A.; Tokles, M.; Snyder, J. K. J. Org. Chem. 1988, 53, 5335-5341. For a similar approach, see Apparu, M.; Ben Tiba, Y.; Leo, P. M.; Hamman, S.; Coulombeau, C. Tetrahedron: Asymmetry 2000, 11, 2885-2898.
} 
shifts of which depend on cis- or trans configuration (Scheme 43a). ${ }^{150}$ Similarly, amino alcohols can be transformed to the corresponding oxazolidinones. (Scheme 43b). ${ }^{9,151}$ The ring protons $\left(\mathrm{H}_{4}, \mathrm{H}_{5}\right)$ of these compounds have coupling constants that are larger for cis- than for trans-configuration, typically ranging from 7-9 Hz and 3-7 Hz, respectively. The configuration can also be confirmed by NOE experiments. ${ }^{9}$

Accordingly, by converting amino alcohols into the corresponding oxazolidinones their relative stereochemistry can be revealed, as syn-amino alcohols give trans-oxazolidinones and anti-amino alcohols give cisoxazolidinones. As the differences in coupling constants and NOE interactions between cis- and trans-oxazolidinones can be small, both isomers of the amino alcohol are often needed for positive assignment. This is true especially for vinyl-substituted oxazolidinones, which often have coupling constants in the range of $7-8 \mathrm{~Hz}$ for both isomers. ${ }^{152}$

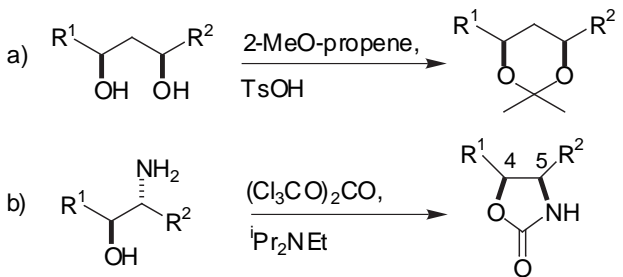

Scheme 43: Transformation of an anti-amino alcohol into a cis-oxazolidinone.

\subsection{Synthesis of Oxazolidinones}

The relative configuration of amino alcohols $2,3,5$ and 6 was determined by conversion to the corresponding oxazolidinones (Scheme 43b, Table 11). When anti-amino alcohols $\mathbf{2 a - d , f , 1 , m}$ and $\mathbf{5 a - d , f , 1 , m}$ were converted into oxazolidinones $\mathbf{4 2 a - d}, \mathbf{f}, \mathbf{l}, \mathbf{m}$ and $\mathbf{4 3 a}-\mathbf{d}, \mathbf{f}, \mathbf{l}, \mathbf{m}$ the coupling constants of the ring protons were 7.8-8.4 and 7.5-8.4 Hz, respectively, which is consistent with cisconfiguration. Oxazolidinones 12a-d,f,l,m (see Chapter 4.2 and 8.4), which show the relative configuration of syn-amino alcohols 3a-d,f,l,m, have coupling constants ranging from 5.4 to $7.2 \mathrm{~Hz}$, confirming trans-configuration. Finally,

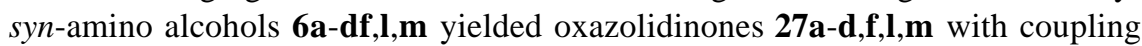
constants between 5.5 and $6.8 \mathrm{~Hz}$, agreeing with trans-configuration. The relative configurations of $12 \mathbf{e}, \mathbf{2 7 e}, \mathbf{4 2 e}$ and $43 \mathbf{e}$ were confirmed by NOESY experiments. Interactions between the ring proton $\left(\mathrm{H}_{4}\right)$ and the methyl group at $\mathrm{C}_{5}$ were present for oxazolidinones $42 \mathbf{e}$ and $43 \mathbf{e}$, indicating cis-configuration.

Also the additional anti-amino alcohols $\mathbf{2 g - k}$ used in the microwave

\footnotetext{
${ }^{150}$ Rychnovsky, S. D.; Richardson, T. I.; Rogers, B. N. J. Org. Chem. 1997, 62, 2925-2934.

${ }^{151}$ Bergmeier, S. C.; Stanchina, D. M. Tetrahedron Lett. 1995, 36, 4533-4536.

152 (a) Ayad, T.; Génisson, Y.; Baltas, M.; Gorrichon, L. Synlett 2001, 866-868. (b) Sakaitani, M.; Ohfune, Y. J. Am. Chem. Soc. 1990, 112, 1150-1158.
} 
aminolysis study (see Chapter 3.2) were transformed into oxazolidinones.

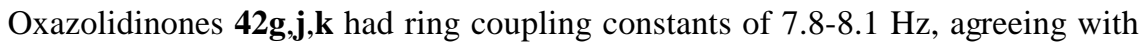

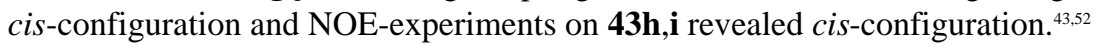

Table 11: Coupling constants of oxazolidinone ring protons $\mathrm{H}_{4}, \mathrm{H}_{5}\left(J_{\mathrm{AB}}\right)$.

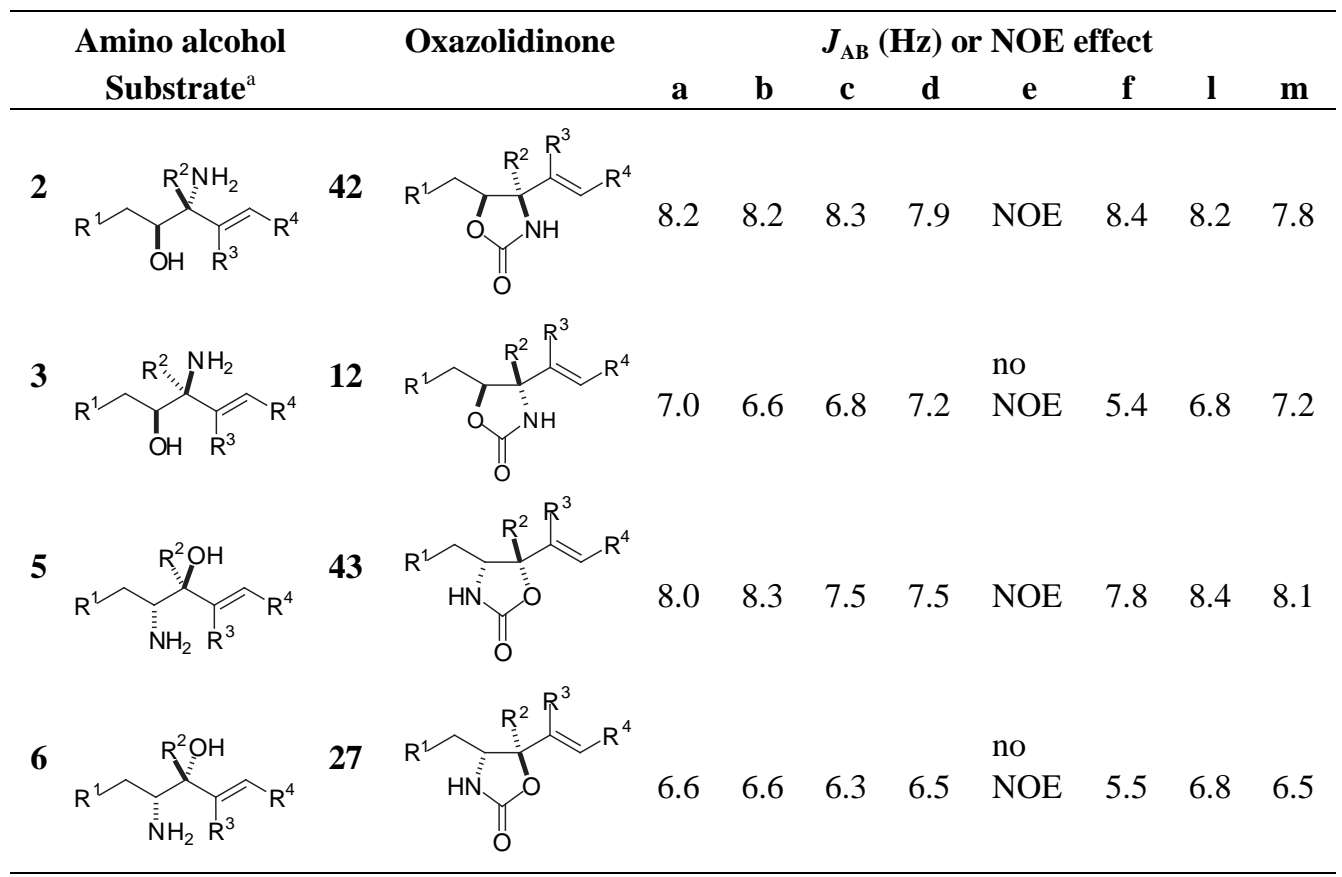

a: $\mathrm{R}^{1}=\mathrm{PhCH}_{2}, \mathrm{R}^{2}=\mathrm{H}, \mathrm{R}^{3}=\mathrm{H}, \mathrm{R}^{4}=\mathrm{H} ; \mathbf{b}: \mathrm{R}^{1}=\mathrm{BnO}, \mathrm{R}^{2}=\mathrm{H}, \mathrm{R}^{3}=\mathrm{H}, \mathrm{R}^{4}=\mathrm{H} ; \mathbf{c}: \mathrm{R}^{1}=\mathrm{BnO}, \mathrm{R}^{2}=\mathrm{H}, \mathrm{R}^{3}=\mathrm{H}$, $\mathrm{R}^{4}=\mathrm{CH}_{2} \mathrm{OPMB} ; \mathbf{d}: \mathrm{R}^{1}=\mathrm{H}, \mathrm{R}^{2}=\mathrm{H}, \mathrm{R}^{3}=\mathrm{H}, \mathrm{R}^{4}=\mathrm{CH}_{2} \mathrm{OBn} ; \mathbf{e}: \mathrm{R}^{1}=\mathrm{CH}_{3}, \mathrm{R}^{2}=\mathrm{CH}_{3}, \mathrm{R}^{3}=\mathrm{H}, \mathrm{R}^{4}=\mathrm{CH}_{2} \mathrm{OBn} \mathbf{f}$ : $\mathrm{R}^{1}=\mathrm{PMBO}, \mathrm{R}^{2}=\mathrm{H}, \mathrm{R}^{3}=\mathrm{CH}_{2} \mathrm{OBn}, \mathrm{R}^{4}=\mathrm{H} ; \mathbf{l}: \mathrm{R}^{1}=\mathrm{BnO}, \mathrm{R}^{2}=\mathrm{H}, \mathrm{R}^{3}=\mathrm{H}, \mathrm{R}^{4}=\mathrm{C}_{13} \mathrm{H}_{27} ; \mathbf{m}: \mathrm{R}^{1}=\mathrm{C}_{13} \mathrm{H}_{27}, \mathrm{R}^{2}=\mathrm{H}$, $\mathrm{R}^{2}=\mathrm{H}, \mathrm{R}^{4}=\mathrm{BnO}$. 


\subsection{NMR determination}

As the transformation of all amino alcohols to oxazolidinones was a rather timeconsuming operation, we sought a simplified method of configuration assignment without need for derivatization. Since we had analysis data of a large amount of amino alcohols at hand, we started looking for trends in ${ }^{13} \mathrm{C}$ NMR or coupling constants that could be used to distinguish syn-and anti-amino alcohols.

Substrates a-d,f,l and $\mathbf{m}$, each with four amino alcohol isomers $(\mathbf{2}, \mathbf{3}, \mathbf{5}$ and $\mathbf{6})$, were used in the study. ${ }^{153}{ }^{13} \mathrm{C}$ NMR data and coupling constants of methine protons $\mathrm{H}_{3}$ and $\mathrm{H}_{4}$ were examined, but to our disappointment no such trends were found (Table 12).

Table 12: Coupling constants and ${ }^{13} \mathrm{C}$ shifts of vinylic amino alcohols 2, 3, 5, 6 .

\begin{tabular}{|c|c|c|c|c|c|c|c|c|}
\hline \multirow{2}{*}{\multicolumn{2}{|c|}{$\begin{array}{c}\text { Amino alcohol } \\
\text { Substrate }^{\mathrm{a}}\end{array}$}} & \multicolumn{7}{|c|}{$J_{\mathrm{AB}}(\mathrm{Hz}) /{ }^{13} \mathrm{C}$ shift $\underline{\mathrm{CH}}-\mathrm{O} / \underline{\mathrm{C}} \mathrm{H}-\mathrm{N}(\mathrm{ppm})$} \\
\hline & & $\mathbf{a}$ & b & c & d & f & 1 & $\mathbf{m}$ \\
\hline \multirow{3}{*}{2} & & 4.0 & $\mathrm{~m}$ & $\mathrm{~m}$ & 3.8 & 6.0 & 4.7 & $\mathrm{~m}$ \\
\hline & & 73.2 & 73.9 & 72.7 & 72.0 & 73.0 & 72.9 & 74.2 \\
\hline & & 59.0 & 57.0 & 55.6 & 58.3 & 57.4 & 56.0 & 57.6 \\
\hline \multirow{3}{*}{3} & & 7.4 & 6.9 & $\mathrm{~m}$ & 7.0 & $\mathrm{~m}$ & $\mathrm{~m}$ & $\mathrm{~m}$ \\
\hline & & 73.2 & 73.5 & 73.3 & 72.8 & 73.0 & 73.5 & 74.0 \\
\hline & & 59.5 & 56.2 & 55.3 & 60.4 & 56.2 & 58.5 & 53.5 \\
\hline \multirow{3}{*}{5} & & $\mathrm{~m}$ & 5.9 & 5.6 & 4.2 & 6.3 & 5.1 & $\mathrm{~m}$ \\
\hline & & 75.0 & 74.6 & 74.4 & 75.3 & 73.2 & 74.8 & 74.0 \\
\hline & & 54.5 & 54.6 & 55.7 & 50.7 & 55.3 & 54.9 & 55.5 \\
\hline \multirow{3}{*}{6} & & 6.0 & 5.3 & 4.8 & 6.4 & $\mathrm{~m}$ & $\mathrm{~m}$ & 5.6 \\
\hline & & 75.4 & 73.4 & 72.6 & 73.6 & 73.2 & 73.4 & 73.5 \\
\hline & $\overline{\mathrm{N}} \mathrm{H}_{2} \mathrm{R}^{2}$ & 54.9 & 54.7 & 54.5 & 51.1 & 55.3 & 55.3 & 55.7 \\
\hline
\end{tabular}

a: $\mathrm{R}^{1}=\mathrm{PhCH}_{2}, \mathrm{R}^{2}=\mathrm{H}, \mathrm{R}^{3}=\mathrm{H} ; \mathbf{b}: \mathrm{R}^{1}=\mathrm{BnO}, \mathrm{R}^{2}=\mathrm{H}, \mathrm{R}^{3}=\mathrm{H} ; \mathbf{c}: \mathrm{R}^{1}=\mathrm{BnO}, \mathrm{R}^{2}=\mathrm{H}, \mathrm{R}^{3}=\mathrm{CH}_{2} \mathrm{OPMB}$; d: $\mathrm{R}^{1}=\mathrm{H}, \mathrm{R}^{2}=\mathrm{H}, \mathrm{R}^{3}=\mathrm{CH}_{2} \mathrm{OBn} ; \mathbf{f}: \mathrm{R}^{1}=\mathrm{PMBO}, \mathrm{R}^{2}=\mathrm{CH}_{2} \mathrm{OBn}, \mathrm{R}^{3}=\mathrm{H} ; \mathrm{l}: \mathrm{R}^{1}=\mathrm{BnO}, \mathrm{R}^{2}=\mathrm{H}$, $\mathrm{R}^{3}=\mathrm{C}_{13} \mathrm{H}_{27} ; \mathbf{m}: \mathrm{R}^{1}=\mathrm{C}_{13} \mathrm{H}_{27}, \mathrm{R}^{2}=\mathrm{H}, \mathrm{R}^{3}=\mathrm{BnO}$.

Surprisingly, there was instead a trend in the ${ }^{1} \mathrm{H}$ NMR shifts, where $\mathrm{H}_{3}$ and $\mathrm{H}_{4}$ shifted more downfield in anti-amino alcohols $\mathbf{2}$ and $\mathbf{5}$ than in the corresponding syn-amino alcohols 3 and 6. For example, the shifts of $\mathrm{C} \underline{\mathrm{H}}-\mathrm{O}$ in $\mathbf{2 a}$ and $\mathbf{3 a}$ were 3.61 and $3.32 \mathrm{ppm}$, respectively. For the same compounds, the shifts of $\underline{\mathrm{C}}-\mathrm{N}$ were 3.36 and $3.14 \mathrm{ppm}$, respectively (Table 13).

${ }^{153}$ Substrate e was excluded as it lacks the allylic proton. 
Table 13: ${ }^{1} \mathrm{H}$ NMR shift (ppm) of $\mathrm{C} \underline{\mathrm{H}}-\mathrm{O} / \mathrm{C} \underline{\mathrm{H}}-\mathrm{N}$ protons in vinylic vic-amino alcohols.

\begin{tabular}{|c|c|c|c|c|c|c|c|c|}
\hline & \multirow[b]{2}{*}{ Amino alcohol ${ }^{\mathrm{a}}$} & \multicolumn{7}{|c|}{ Shift (ppm) of Cㅍ-O / Cㅍ-N protons } \\
\hline & & $\mathbf{a}$ & b & c & d & f & 1 & $\mathbf{m}$ \\
\hline \multirow[b]{2}{*}{2} & & 3.61 & 3.78 & 3.77 & 3.73 & 3.83 & 3.74 & 3.53 \\
\hline & & 3.36 & 3.50 & 3.51 & 3.29 & 3.63 & 3.42 & 3.40 \\
\hline \multirow[b]{2}{*}{3} & & 3.32 & 3.50 & 3.58 & 3.45 & 3.70 & 3.53 & 3.29 \\
\hline & & 3.14 & 3.40 & 3.43 & 3.06 & 3.40 & 3.34 & 3.14 \\
\hline \multirow[b]{2}{*}{5} & & 4.07 & 4.11 & 4.15 & 4.00 & 4.10 & 4.04 & 4.24 \\
\hline & & 2.94 & 3.06 & 3.06 & 3.00 & 3.12 & 3.03 & 2.85 \\
\hline \multirow[b]{2}{*}{6} & & 3.85 & 4.08 & 4.08 & 3.73 & 3.92 & 3.96 & 3.91 \\
\hline & $\overline{\overline{\mathrm{N}}} \mathrm{H}_{2} \mathrm{R}^{2}$ & 2.67 & 2.97 & 2.94 & 2.81 & 3.04 & 2.88 & 2.72 \\
\hline
\end{tabular}

${ }^{a}$ a: $\mathrm{R}^{1}=\mathrm{PhCH}_{2}, \mathrm{R}^{2}=\mathrm{H}, \mathrm{R}^{3}=\mathrm{H} ; \mathbf{b}: \mathrm{R}^{1}=\mathrm{BnO}, \mathrm{R}^{2}=\mathrm{H}, \mathrm{R}^{3}=\mathrm{H} ; \mathbf{c}: \mathrm{R}^{1}=\mathrm{BnO}, \mathrm{R}^{2}=\mathrm{H}, \mathrm{R}^{3}=\mathrm{H} ; \mathbf{d}$ : $\mathrm{R}^{1}=\mathrm{H}, \mathrm{R}^{2}=\mathrm{H}, \mathrm{R}^{3}=\mathrm{CH}_{2} \mathrm{OBn} ; \mathbf{f}: \mathrm{R}^{1}=\mathrm{PMBO}, \mathrm{R}^{2}=\mathrm{CH}_{2} \mathrm{OBn}, \mathrm{R}^{3}=\mathrm{H} ; \mathbf{l}: \mathrm{R}^{1}=\mathrm{BnO}, \mathrm{R}^{2}=\mathrm{H}$, $\mathrm{R}^{3}=\mathrm{C}_{13} \mathrm{H}_{27} ; \mathbf{m}: \mathrm{R}^{1}=\mathrm{C}_{13} \mathrm{H}_{27}, \mathrm{R}^{2}=\mathrm{H}, \mathrm{R}^{3}=\mathrm{BnO}$.

Satisfied with this observation, we wanted to see whether the trend was applicable also to saturated vic-amino alcohols. Amino alcohols 2, 3, 5 and 6 of substrates $\mathbf{a}, \mathbf{b}, \mathbf{d}, \mathbf{l}$ and $\mathbf{m}$ were reduced with hydrazine and hydrogen peroxide to the corresponding saturated compounds 2', 3', 5' and '6' (Scheme 44)..$^{154,155}$

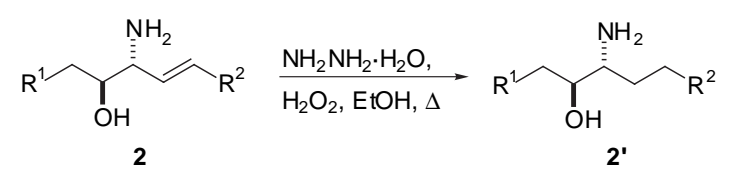

Scheme 44: Hydrazine reduction of the vinyl group.

To our delight, the saturated amino alcohols 2', 3', 5', 6' showed the same trend in ${ }^{1} \mathrm{H}$ NMR shifts (Table 14). Thus, complexation or derivatization of vicamino alcohols is not needed for determination of relative configuration. Instead simple ${ }^{1} \mathrm{H}$ NMR analysis is sufficient to reveal syn/anti relationship when both of the isomers of a given amino alcohol are present, as the ${ }^{1} \mathrm{H}$ NMR shifts of $\mathrm{C}$ and $\mathrm{C}$ H-N protons are more downfield in the anti-amino alcohol than in the corresponding syn-isomer.

\footnotetext{
${ }^{154}$ Yadav, J. S.; Sreenivasa Rao, E.; Sreenivasa Rao, V. Synth. Commun. 1989, 19, 705-711.

${ }^{155}$ Substrate $\mathbf{c}$ was excluded due to lack of material, substrate $\mathbf{f}$ as is would give two diastereomers upon reduction.
} 
Table 14: ${ }^{1} \mathrm{H}$ NMR shift of $\mathrm{C} \underline{H}-\mathrm{O} / \mathrm{C} \underline{H}-\mathrm{N}$ protons in saturated vic-amino alcohols.

\begin{tabular}{lllllll}
\multicolumn{6}{c}{ Shift of $\mathbf{C}-\mathbf{H} / \mathbf{C}-\mathbf{H}$ protons (ppm) } \\
\hline
\end{tabular}

a: $\mathrm{R}^{1}=\mathrm{PhCH}_{2}, \mathrm{R}^{2}=\mathrm{H} ; \mathbf{b}: \mathrm{R}^{1}=\mathrm{BnO}, \mathrm{R}^{2}=\mathrm{H} ; \mathbf{d}: \mathrm{R}^{1}=\mathrm{H}, \mathrm{R}^{2}=\mathrm{CH}_{2} \mathrm{OBn} ; \mathbf{l}: \mathrm{R}^{1}=\mathrm{BnO}$, $\mathrm{R}^{2}=\mathrm{C}_{13} \mathrm{H}_{27}, \mathbf{m}: \mathrm{R}^{1}=\mathrm{C}_{13} \mathrm{H}_{27}, \mathrm{R}^{2}=\mathrm{BnO}$. 


\section{Concluding remarks}

A synthetic strategy that provides a straightforward route from vinylepoxides $\mathbf{1}$ to the four isomeric vic-amino alcohols $\mathbf{2}, \mathbf{3}, \mathbf{5}$ and $\mathbf{6}$ has been presented. Since ent-1 is available from the same starting material as $\mathbf{1}$, all eight possible isomers of a given amino alcohol can be synthesized using this procedure. As an application of the presented route towards amino alcohols, the synthesis of sphingosine and three of its isomers has been detailed.

The synthesis of vinylepoxides $\mathbf{1}$ has been simplified by application of an enantioselective monoepoxidation of dienes, making the starting materials used in this route readily available in both enantiomeric forms. Moreover, two efficient protocols for the regioselective and stereospecific aminolysis of vinylepoxides have been presented. Compared to previous methods, these procedures use milder reaction conditions, shorter reaction times, generally give higher yields and are applicable to a larger set of substrates.

Furthermore, the ring-closure of vic-amino alcohols to the corresponding $\mathrm{N}-\mathrm{H}$ vinylaziridines has been investigated. Three routes were found useful, which one is preferred depends on substrate and scale.

Finally, a rapid way of determining the relative configuration of vic-amino alcohols has been developed, which should be of substantial use when amino alcohols are formed by diastereoselective reactions. 


\section{Acknowledgements}

Jag skulle vilja tacka alla som stöttat och hjälpt mig genom denna, tidvis mycket roliga och tidvis rätt jobbiga, fyraårsperiod. Ett särskilt tack till...

...min handledare Peter Somfai, för att jag fått del av din kunskap och ditt engagemang.

...alla nuvarande och gamla medlemmar av PS-gruppen, särskilt Ulf, för all hjälp och bra konserter och Janne, som hållit ordning och fixat bra musik på lab!

...alla avdelningskollegor på SU och KTH; mer innebandy till folket!

...Acta Chemica Scandinavica, Aulin-Erdtmans Stiftelse, Lars Gunnar Silléns minnesfond, Svenska Kemistsamfundet samt Kungl. Vetenskapsakademin/ Hierta-Retzius stipendiefond för stipendier.

...Janne och Gunhild Aulin-Erdtman för korrelturläsning av denna avhandling.

...alla vänner för att ni stått ut fastän jag nästan aldrig har haft tid. Speciellt tack till Reneé och Leffe för Emmy, trevliga söndagar och festfixande och till Bengt för all hjälp med Umbra.

...min familj, för att ni alltid finns där när det behövs.

...Peter \& Emmy, ni är dom bästa som finns! 


\section{Appendix A}

The following is a description of my contribution to publications I-VII, as requested by $\mathrm{KTH}$ :

I. I shared lab work and writing of the paper with Dr. U. M. Lindström.

II. I performed all initial reaction optimizations, did the transformations of substrates a-c to the corresponding amino alcohols and the analyses of compounds a-d. Dr. U. Khamrai prepared and reacted substrate 1d. I wrote the article.

III. This paper was written on invitation, and is a more detailed form of paper II. I wrote the article.

IV. I performed all lab work apart from what is described above for paper II. I wrote the article.

V. I supervised the diploma worker R. Wijtmans, who made the initial investigations apart from the Mitsunobu chemistry. I optimized the reactions, did the analysis work and wrote the article.

VI. I performed all lab work and wrote the article.

VII. I performed all lab work and wrote the article. 


\section{Appendix B}

This appendix contains experimental details for paper VII and analytical data of compounds 1k, 2m-6m, 10m, 12m, 16-19, 20m, 21e, 22m, 23-26, 27m, 40m and $41 \mathrm{~m}$.

\section{B.1 Compounds " $\mathrm{m}$ " in the Sphingosine route (Chapter 8)}

Amino alcohols $\mathbf{2 m}, \mathbf{3 m}, \mathbf{5 m}$ and $\mathbf{6 m}$ were used in the NMR-study described in Chapter 9, and synthesized according to the general procedures described in publications IV and VI.

(2E,4S,5R)-4-Amino-1-benzyloxy-octadec-2-en-5-ol (2m):

${ }^{1} \mathrm{H}$ NMR (400 MHz, $\left.\mathrm{CDCl}_{3}\right): \delta$ 7.38-7.26 (m, 5H), $5.77(\mathrm{~m}, 2 \mathrm{H}), 4.52(\mathrm{~s}, 2 \mathrm{H})$, $4.04(\mathrm{~m}, 2 \mathrm{H}), 3.53(\mathrm{~m}, 1 \mathrm{H}), 3.40(\mathrm{~m}, 1 \mathrm{H}), 1.77$ (br s, 3H), $1.37(\mathrm{~m}, 2 \mathrm{H}), 1.26(\mathrm{~m}$, $22 \mathrm{H}), 0.88(\mathrm{t}, 3 \mathrm{H}, J=6.8 \mathrm{~Hz}) ;{ }^{13} \mathrm{C} \mathrm{NMR}\left(125 \mathrm{MHz}, \mathrm{CDCl}_{3}\right): \delta 138.3,133.2$, $128.7,127.8,127.7,74.2,72.3,70.4,57.6,33.0,31.9,29.8,29.7,29.7,29.7$, 29.7, 29.6, 29.6, 29.4, 26.0, 22.7, 14.1; IR (neat): 3320, 2915, $2849 \mathrm{~cm}^{-1}$.

(2E,4S,5S)-4-Amino-1-benzyloxy-octadec-2-en-5-ol (3m):

${ }^{1} \mathrm{H}$ NMR (400 MHz, $\mathrm{CDCl}_{3}$ ): $\delta$ 7.38-7.26 (m, 5H), $5.77(\mathrm{dt}, 1 \mathrm{H}, J=15.7,4.6$ $\mathrm{Hz}), 5.71(\mathrm{dd}, 1 \mathrm{H}, J=15.7,6.0 \mathrm{~Hz}), 4.52(\mathrm{~s}, 2 \mathrm{H}), 4.02(\mathrm{~d}, 2 \mathrm{H}, J=4.6 \mathrm{~Hz}), 3.29$ $(\mathrm{m}, 1 \mathrm{H}), 3.14(\mathrm{~m}, 1 \mathrm{H}), 1.81(\mathrm{br} \mathrm{s}, 3 \mathrm{H}), 1.51(\mathrm{~m}, 2 \mathrm{H}), 1.27(\mathrm{~m}, 22 \mathrm{H}), 0.88(\mathrm{t}, 3 \mathrm{H}$, $J=6.8 \mathrm{~Hz}) ;{ }^{13} \mathrm{C}$ NMR $\left(125 \mathrm{MHz}, \mathrm{CDCl}_{3}\right): \delta 138.1,128.4,127.9,127.8,127.7$, 127.6, 74.0, 72.3, 70.3, 53.5, 33.8, 31.9, 29.7, 29.7, 29.7, 29.6, 29.6, 29.6, 29.6, 29.3, 25.8, 22.7, 14.1; IR (neat): $3351,2918,2847 \mathrm{~cm}^{-1}$.

(2S,3S)-2-(3-Benzyloxy-(E)-propenyl)-3-tridecyl-aziridine (4m):

${ }^{1} \mathrm{H}$ NMR (400 MHz, $\left.\mathrm{CDCl}_{3}\right): \delta$ 7.39-7.27 (m, 5H), $5.89(\mathrm{dt}, 1 \mathrm{H}, J=15.5,5.8$ $\mathrm{Hz}), 5.36(\mathrm{dd}, 1 \mathrm{H}, J=15.5,8.4 \mathrm{~Hz}), 4.54(\mathrm{~s}, 2 \mathrm{H}), 4.03(\mathrm{dd}, 2 \mathrm{H}, J=5.9,1.3 \mathrm{~Hz})$, $2.21(\mathrm{dd}, 1 \mathrm{H}, J=8.3,2.6 \mathrm{~Hz}), 1.89(\mathrm{~m}, 1 \mathrm{H}), 1.44(\mathrm{~m}, 2 \mathrm{H}), 1.28(\mathrm{~m}, 22 \mathrm{H}), 0.90$ $(\mathrm{t}, 3 \mathrm{H}, J=6.8 \mathrm{~Hz}) ;{ }^{13} \mathrm{C}$ NMR $\left(125 \mathrm{MHz}, \mathrm{CDCl}_{3}\right): \delta 138.2,134.2,128.4,127.9$, 127.8, 127.6, 72.3, 70.3, 39.4, 38.5, 33.8, 31.9, 29.7, 29.7, 29.7, 29.7, 29.6, 29.4, 29.4, 29.2, 27.4, 22.7, 14.1; IR (neat): $2925,2853 \mathrm{~cm}^{-1}$.

(2E,4R,5S)-5-Amino-1-benzyloxy-octadec-2-en-4-ol (5m):

${ }^{1} \mathrm{H}$ NMR (400 MHz, $\mathrm{CDCl}_{3}$ ): $\delta$ 7.35-7.27 (m, 5H), $5.90(\mathrm{dt}, 1 \mathrm{H}, J=16.1,5.8$ $\mathrm{Hz}), 5.76(\mathrm{dd}, 1 \mathrm{H}, J=16.1,5.9 \mathrm{~Hz}), 4.52(\mathrm{~s}, 2 \mathrm{H}), 4.24(\mathrm{~m}, 1 \mathrm{H}), 4.06(\mathrm{~d}, 2 \mathrm{H}, J=$ $6.0 \mathrm{~Hz}), 2.85(\mathrm{~m}, 1 \mathrm{H}), 2.01$ (br s, 3H), $1.43(\mathrm{~m}, 2 \mathrm{H}), 1.26(\mathrm{~m}, 22 \mathrm{H}), 0.88(\mathrm{t}, 3 \mathrm{H}$, $J=6.8 \mathrm{~Hz}) ;{ }^{13} \mathrm{C}$ NMR $\left(125 \mathrm{MHz}, \mathrm{CDCl}_{3}\right): \delta 138.2,131.1,129.3,128.4,127.7$, 127.7, 74.0, 72.3, 70.2, 55.5, 33.4, 31.9, 29.7, 29.7, 29.7, 29.6, 29.6, 29.6, 29.6, 29.4, 26.4, 22.7, 14.1; IR (neat): $3373,2926,2855 \mathrm{~cm}^{-1}$. 
(2E,4S,5S)-5-Amino-1-benzyloxy-octadec-2-en-4-ol (6m):

${ }^{1} \mathrm{HNMR}\left(400 \mathrm{MHz}, \mathrm{CDCl}_{3}\right): \delta 7.39-7.26(\mathrm{~m}, 5 \mathrm{H}), 5.91(\mathrm{dt}, 1 \mathrm{H}, J=15.4,5.2 \mathrm{~Hz})$, $5.74(\mathrm{dd}, 1 \mathrm{H}, J=15.4,5.6 \mathrm{~Hz}), 4.52(\mathrm{~s}, 2 \mathrm{H}), 4.05(\mathrm{~d}, 2 \mathrm{H}, J=5.0 \mathrm{~Hz}), 3.91(\mathrm{t}$, $1 \mathrm{H}, J=5.6 \mathrm{~Hz}), 3.08($ br s, 3H), $2.72(\mathrm{~m}, 1 \mathrm{H}), 1.58(\mathrm{~m}, 1 \mathrm{H}), 1.42(\mathrm{~m}, 1 \mathrm{H}), 1.26$ $(\mathrm{m}, 22 \mathrm{H}), 0.88(\mathrm{t}, 3 \mathrm{H}, J=6.8 \mathrm{~Hz}) ;{ }^{13} \mathrm{C} \mathrm{NMR}\left(125 \mathrm{MHz}, \mathrm{CDCl}_{3}\right): \delta 138.2,133.1$, 129.2, 128.4, 127.7, 127.7, 73.5, 72.3, 70.1, 55.7, 33.4, 31.9, 29.7, 29.7, 29.7, 29.6, 29.6, 29.6, 29.6, 29.4, 26.1, 22.7, 14.1; IR (neat): 3356, 2925, $2854 \mathrm{~cm}^{-1}$.

(4S,5S)-4-(3-Benzyloxy-(E)-propenyl)-3-(toluene-4-sulfonyl)-5-tridecyloxazolidin-2-one (10m): ${ }^{1} \mathrm{H}$ NMR $\left(400 \mathrm{MHz}, \mathrm{CDCl}_{3}\right): \delta 7.89(\mathrm{~d}, 1 \mathrm{H}, J=8.4$ $\mathrm{Hz}), 7.38-7.23(\mathrm{~m}, 7 \mathrm{H}), 5.99(\mathrm{dt}, 1 \mathrm{H}, J=15.4,4.9 \mathrm{~Hz}), 5.71$ (ddt, $1 \mathrm{H}, J=15.4$, 8.7, $1.7 \mathrm{~Hz}), 4.55(\mathrm{~s}, 2 \mathrm{H}), 4.52(\mathrm{~m}, 1 \mathrm{H}), 4.13(\mathrm{~m}, 1 \mathrm{H}), 4.07(\mathrm{dd}, 1 \mathrm{H}, J=4.9,1.7$ $\mathrm{Hz}), 2.41(\mathrm{~s}, 3 \mathrm{H}), 1.64(\mathrm{~m}, 2 \mathrm{H}), 1.26(\mathrm{~m}, 22 \mathrm{H}), 0.88(\mathrm{t}, 3 \mathrm{H}, J=6.8 \mathrm{~Hz})$.

(4S,5S)-4-(3-Benzyloxy-(E)-propenyl)-5-tridecyl-oxazolidin-2-one (12m): ${ }^{1} \mathrm{H}$ NMR (400 MHz, $\mathrm{CDCl}_{3}$ ): $\delta$ 7.38-7.28 (m, 5H), $5.85(\mathrm{dt}, 1 \mathrm{H}, J=15.5,5.2$ $\mathrm{Hz}), 5.71(\mathrm{ddt}, 1 \mathrm{H}, J=15.5,7.7,1.4 \mathrm{~Hz}), 5.06(\mathrm{~s}, 1 \mathrm{H}), 4.53(\mathrm{~s}, 2 \mathrm{H}), 4.20(\mathrm{td}, 1 \mathrm{H}$, $J=7.2,4.7 \mathrm{~Hz}), 4.03(\mathrm{dd}, 1 \mathrm{H}, J=5.2,1.4 \mathrm{~Hz}), 3.96($ br t $, 1 \mathrm{H}, J=7.4 \mathrm{~Hz}), 1.69$ $(\mathrm{m}, 2 \mathrm{H}), 1.48(\mathrm{~m}, 2 \mathrm{H}), 1.26(\mathrm{~m}, 20 \mathrm{H}), 0.88(\mathrm{t}, 3 \mathrm{H}, J=6.8 \mathrm{~Hz}) ;{ }^{13} \mathrm{C}$ NMR $(100$ $\left.\mathrm{MHz}, \mathrm{CDCl}_{3}\right): \delta 158.5,137.8,131.4,129.6,128.5,127.9,127.8,82.6,72.8,69.3$, 60.2 , 33.8, 31.9, 29.7, 29.7, 29.6, 29.6, 29.5, 29.4, 29.4, 29.3, 24.9, 22.7, 14.1 .

1-[2S-(3-Benzyloxy-(E)-propenyl)-3S-tridecyl-aziridin-1-yl]-ethanone (20m): ${ }^{1} \mathrm{H}$ NMR (400 MHz, $\left.\mathrm{CDCl}_{3}\right): \delta$ 7.36-7.26 (m, 5H), $6.03(\mathrm{dt}, 1 \mathrm{H}, J=15.4,5.6$ $\mathrm{Hz}), 5.26(\mathrm{ddt}, 1 \mathrm{H}, J=15.4,5.3,1.3 \mathrm{~Hz}), 4.54(\mathrm{~s}, 2 \mathrm{H}), 4.02(\mathrm{dd}, 2 \mathrm{H}, J=5.6,1.3$ $\mathrm{Hz}), 2.87(\mathrm{~m}, 1 \mathrm{H}), 2.46(\mathrm{td}, 1 \mathrm{H}, J=5.6,2.8 \mathrm{~Hz}), 2.07(\mathrm{~s}, 3 \mathrm{H}), 1.42(\mathrm{~m}, 2 \mathrm{H}), 1.26$ $(\mathrm{m}, 22 \mathrm{H}), 1.18(\mathrm{t}, 3 \mathrm{H}, J=7.2 \mathrm{~Hz})$.

(1S,2S)- $\mathrm{N}$-(5-Benzyloxy-2-hydroxy-1-tridecyl-pent-3-(E)-enyl)-acetamide (22m): ${ }^{1} \mathrm{H}$ NMR (400 MHz, $\mathrm{CDCl}_{3}$ ): $\delta$ 7.37-7.27 (m, 5H), $5.85(\mathrm{dt}, 1 \mathrm{H}, J=15.6$, $5.6 \mathrm{~Hz}), 5.76(\mathrm{dd}, 1 \mathrm{H}, J=15.6,5.8 \mathrm{~Hz}), 5.90(\mathrm{br} \mathrm{d}, 1 \mathrm{H}, J=9.1 \mathrm{~Hz}), 4.50(\mathrm{~s}, 2 \mathrm{H})$, $4.17(\mathrm{dd}, 1 \mathrm{H}, J=5.8,4.0 \mathrm{~Hz}), 4.02(\mathrm{~d}, 2 \mathrm{H}, J=5.6 \mathrm{~Hz}), 3.88(\mathrm{~m}, 1 \mathrm{H}), 1.98(\mathrm{~s}$, $3 \mathrm{H}), 1.60(\mathrm{~m}, 1 \mathrm{H}), 1.48(\mathrm{~m}, 1 \mathrm{H}), 1.26(\mathrm{~m}, 22 \mathrm{H}), 0.88(\mathrm{t}, 3 \mathrm{H}, J=7.2 \mathrm{~Hz})$.

(4S,5S)-5-(3-Benzyloxy-(E)-propenyl)-4-tridecyl-oxazolidin-2-one (27m):

${ }^{1} \mathrm{H}$ NMR (400 MHz, $\left.\mathrm{CDCl}_{3}\right): \delta$ 7.39-7.27 (m, 5H), $5.97(\mathrm{dt}, 1 \mathrm{H}, J=15.5,5.0$ $\mathrm{Hz}), 5.83$ (ddt, $1 \mathrm{H}, J=15.5,7.8,1.4 \mathrm{~Hz}), 5.09(\mathrm{br} \mathrm{s}, 1 \mathrm{H}), 4.60(\mathrm{t}, 1 \mathrm{H}, J=6.5$ $\mathrm{Hz}), 4.54(\mathrm{~s}, 2 \mathrm{H}), 4.07$ (dd, 2H, $J=5.0,1.4 \mathrm{~Hz}), 3.52$ (app. q, $1 \mathrm{H}, J=6.5 \mathrm{~Hz}$ ), $1.30(\mathrm{~m}, 2 \mathrm{H}), 1.26(\mathrm{~m}, 22 \mathrm{H}), 0.88(\mathrm{t}, 3 \mathrm{H}, J=6.8 \mathrm{~Hz}) ;{ }^{13} \mathrm{C}$ NMR $(125 \mathrm{MHz}$, $\left.\mathrm{CDCl}_{3}\right): \delta 158.3,138.0,131.8,128.5,127.9,127.8,127.7,82.3,72.6,69.3,58.4$, $31.9,29.7,29.6,29.6,29.5,29.5,29.4,29.4,29.3,29.3,25.6,22.7,14.1$; IR (neat): $3396,2925,2854,1756 \mathrm{~cm}^{-1}$.

(4S,5R)-4-(3-Benzyloxy-(E)-propenyl)-5-tridecyl-oxazolidin-2-one (42m): 
${ }^{1} \mathrm{H}$ NMR (400 MHz, $\left.\mathrm{CDCl}_{3}\right): \delta$ 7.39-7.28 (m, 5H), $5.83(\mathrm{dt}, 1 \mathrm{H}, J=15.5,5.2$ $\mathrm{Hz}$ ), 5.73 (ddt, $1 \mathrm{H}, J=15.5,7.8,1.2 \mathrm{~Hz}$ ), 5.03 (br s, $1 \mathrm{H}), 4.62$ (dt, $1 \mathrm{H}, J=7.8$, $4.0 \mathrm{~Hz}), 4.53(\mathrm{~s}, 2 \mathrm{H}), 4.28(\mathrm{t}, 1 \mathrm{H}, J=7.8 \mathrm{~Hz}), 4.04(\mathrm{dd}, 2 \mathrm{H}, J=5.2,1.2 \mathrm{~Hz})$, $1.66(\mathrm{~m}, 2 \mathrm{H}), 1.48(\mathrm{~m}, 2 \mathrm{H}), 1.26(\mathrm{~m}, 20 \mathrm{H}), 0.88(\mathrm{t}, 3 \mathrm{H}, J=6.8 \mathrm{~Hz}) ;{ }^{13} \mathrm{C} \mathrm{NMR}$ $\left(100 \mathrm{MHz}, \mathrm{CDCl}_{3}\right): \delta 158.8,137.9,131.9,128.5,127.8,127.7,127.2,80.3,72.6$, 69.4, 57.5, 31.9, 30.4, 29.7, 29.6, 29.6, 29.5, 29.4, 29.4, 29.3, 29.3, 25.7, 22.7, 14.1 .

(4R,5S)-5-(3-Benzyloxy-(E)-propenyl)-4-tridecyl-oxazolidin-2-one (43m): ${ }^{1} \mathrm{H}$ NMR (500 MHz, $\mathrm{CDCl}_{3}$ ): $\delta$ 7.37-7.27 (m, 5H), $5.99(\mathrm{dt}, 1 \mathrm{H}, J=15.6,5.0$ $\mathrm{Hz}$ ), 5.83 (ddt, $1 \mathrm{H}, J=15.6,7.5,1.4 \mathrm{~Hz}$ ), 5.08 (br t, $1 \mathrm{H}, J=7.7 \mathrm{~Hz}$ ), 5.06 (br s, $1 \mathrm{H}), 4.54(\mathrm{~s}, 2 \mathrm{H}), 4.08(\mathrm{~d}, 2 \mathrm{H}, J=5.0 \mathrm{~Hz}), 3.82(\mathrm{td}, 2 \mathrm{H}, J=8.1,5.8 \mathrm{~Hz}), 1.45$ $(\mathrm{m}, 2 \mathrm{H}), 1.26(\mathrm{~m}, 22 \mathrm{H}), 0.88(\mathrm{t}, 3 \mathrm{H}, J=6.9 \mathrm{~Hz}) ;{ }^{13} \mathrm{C} \mathrm{NMR}\left(125 \mathrm{MHz}, \mathrm{CDCl}_{3}\right)$ : $\delta$ 158.6,138.0, 133.0, 128.5, 127.8, 127.7, 124.6, 80.1, 72.5, 69.3, 56.1, 32.0, $31.0,29.7,29.7,29.7,29.6,29.5,29.5,29.4,29.4,26.2,22.7,14.1$; IR (neat): $3261,2922,2851,1757 \mathrm{~cm}^{-1}$.

\section{B.2 Reduction of vinylic amino alcohols (Chapter 9)}

\section{Typical procedure:}

Amino alcohol $(0.125 \mathrm{mmol}), \mathrm{NH}_{2} \mathrm{NH}_{2} \cdot \mathrm{H}_{2} \mathrm{O}(122 \mu \mathrm{L}, 2.5 \mathrm{mmol})$ and $\mathrm{H}_{2} \mathrm{O}_{2}(35 \%$ wt, $80 \mu \mathrm{L}, 0.88 \mathrm{mmol})$ were dissolved in $\mathrm{EtOH}(95 \%, 0.5 \mathrm{~mL})$. the mixture was heated to $100{ }^{\circ} \mathrm{C}$ in a sealed tube until finished (very substrate dependent, $1 \mathrm{~h}$ to 3 days). Water $(1 \mathrm{~mL})$ and $\mathrm{CH}_{2} \mathrm{Cl}_{2}(2 \mathrm{~mL})$ were added to the reaction mixture followed by filtration through an Extrelut ${ }^{\circledR}$ NT3 tube. The organic phase was eluted with $\mathrm{CH}_{2} \mathrm{Cl}_{2}(15 \mathrm{~mL})$ and concentrated. No further purification was needed.

\section{B.2.1 Reduction of 2 to $2^{\prime}$}

(3S,4R)-4-Amino-1-phenyl-hexan-3-ol (2a'):

${ }^{1} \mathrm{H}$ NMR $\left(400 \mathrm{MHz}, \mathrm{CDCl}_{3}\right): \delta$ 7.30-7.16 (m, 5H), $3.50(\mathrm{~m}, 1 \mathrm{H}), 2.90(\mathrm{~m}, 1 \mathrm{H})$, $2.64(\mathrm{~m}, 2 \mathrm{H}), 1.94$ (br s, 3H), $1.67(\mathrm{~m}, 2 \mathrm{H}), 1.48$ (dqd, 1H, J=13.8, 7.5, 4.1 Hz), $1.26(\mathrm{ddq}, 1 \mathrm{H}, J=13.8,9.1,7.5 \mathrm{~Hz}), 0.92(\mathrm{t}, 3 \mathrm{H}, J=7.5 \mathrm{~Hz}) ;{ }^{13} \mathrm{C}$ NMR $(100$ $\left.\mathrm{MHz}, \mathrm{CDCl}_{3}\right): \delta 142.3,128.4,128.3,125.7,73.1,57.2,33.3,32.5,25.2,11.0$; IR (neat): $3341,2971,2849 \mathrm{~cm}^{-1}$.

\section{(2R,3R)-3-Amino-1-benzyloxy-pentan-2-ol (2b')}

${ }^{1} \mathrm{H}$ NMR (400 MHz, $\left.\mathrm{CDCl}_{3}\right): \delta 7.38-7.26(\mathrm{~m}, 5 \mathrm{H}), 4.55(\mathrm{~s} .2 \mathrm{H}), 3.67(\mathrm{~m}, 1 \mathrm{H})$, $3.61(\mathrm{dd}, 1 \mathrm{H}, J=9.6,3.1 \mathrm{~Hz}), 3.57(\mathrm{dd}, 1 \mathrm{H}, J=9.6,3.7 \mathrm{~Hz}), 2.79(\mathrm{dt}, 1 \mathrm{H}, J=$ 8.9, $4.5 \mathrm{~Hz}$ ), 1.95 (br s, 3H), 1.57 (dqd, $1 \mathrm{H}, J=13.8,7.5,4.3 \mathrm{~Hz}$ ), 1.29 (ddq, $1 \mathrm{H}$, $J=13.8,8.9,7.5 \mathrm{~Hz}), 0.96(\mathrm{t}, 3 \mathrm{H}, J=7.5 \mathrm{~Hz}) ;{ }^{13} \mathrm{C} \mathrm{NMR}\left(125 \mathrm{MHz}, \mathrm{CDCl}_{3}\right): \delta$ $138.0,128.4,127.7,127.6,73.5,72.9,71.5,55.2,26.3,10.8$; IR (neat): 3362 , $2964,2873 \mathrm{~cm}^{-1}$. 
(2R,3S)-3-Amino-6-benzyloxy-hexan-2-ol (2d'):

${ }^{1} \mathrm{H}$ NMR (400 MHz, $\left.\mathrm{CDCl}_{3}\right): \delta 7.37-7.26(\mathrm{~m}, 5 \mathrm{H}), 4.51(\mathrm{~s}, 2 \mathrm{H}), 3.72(\mathrm{dq}, 1 \mathrm{H}, J=$ $6.4,3.8 \mathrm{~Hz}), 3.50(\mathrm{t}, 2 \mathrm{H}, J=6.2 \mathrm{~Hz}), 2.78(\mathrm{~m}, 1 \mathrm{H}), 1.98(\mathrm{br} \mathrm{s}, 3 \mathrm{H}), 1.78(\mathrm{~m}, 1 \mathrm{H})$, $1.63(\mathrm{~m}, 1 \mathrm{H}), 1.54(\mathrm{~m}, 1 \mathrm{H}), 1.31(\mathrm{~m}, 1 \mathrm{H}), 1.09(\mathrm{~d}, 3 \mathrm{H}, J=6.4 \mathrm{~Hz}) ;{ }^{13} \mathrm{C} \mathrm{NMR}$ $\left(100 \mathrm{MHz}_{\mathrm{CDCl}}\right): \delta 138.4,128.7,127.8,127.6,73.0,70.2,69.7,55.8,29.6$, 26.8, 17.0; IR (neat): 3296, 2939, $2866 \mathrm{~cm}^{-1}$.

(2S,3S)-3-Amino-1-benzyloxy-octadecan-2-ol (21'):

${ }^{1} \mathrm{H}$ NMR (500 MHz, $\left.\mathrm{CDCl}_{3}\right): \delta$ 7.37-7.25 (m, 5H), $4.55(\mathrm{AB}-\mathrm{q}, 2 \mathrm{H}, J=11.9 \mathrm{~Hz})$, $3.65(\mathrm{~m}, 1 \mathrm{H}), 3.61(\mathrm{dd}, 1 \mathrm{H}, J=9.6,3.2 \mathrm{~Hz}), 3.57(\mathrm{dd}, 1 \mathrm{H}, J=9.6,6.7 \mathrm{~Hz}), 2.87$ (m, 1H), 1.80 (br s, 3H), $1.47(\mathrm{~m}, 2 \mathrm{H}), 1.26(\mathrm{~m}, 26 \mathrm{H}), 0.88(\mathrm{t}, 3 \mathrm{H}, J=6.9 \mathrm{~Hz})$; ${ }^{13} \mathrm{C} \mathrm{NMR}\left(125 \mathrm{MHz}, \mathrm{CDCl}_{3}\right): \delta 138.1,128.5,127.7,127.7,73.6,73.2,71.4$, 53.7, 33.6, 31.9, 29.7, 29.7, 29.7, 29.7, 29.7, 29.7, 29.6, 29.6, 29.6, 29.4, 26.5, 22.7, 14.2; IR (neat): 3361, 2925, $2854 \mathrm{~cm}^{-1}$.

(4S,5R)-4-Amino-1-benzyloxy-octadecan-5-ol (2m'):

${ }^{1} \mathrm{H} \mathrm{NMR}\left(400 \mathrm{MHz}, \mathrm{CDCl}_{3}\right): \delta 7.38-7.26(\mathrm{~m}, 5 \mathrm{H}), 4.51(\mathrm{~s}, 2 \mathrm{H}), 3.50(\mathrm{t}, 2 \mathrm{H}, J=$ $6.3 \mathrm{~Hz}), 3.46(\mathrm{~m}, 1 \mathrm{H}), 2.77(\mathrm{~m}, 1 \mathrm{H}), 1.82-1.48(\mathrm{~m}, 7 \mathrm{H}), 1.27(\mathrm{~m}, 24 \mathrm{H}), 0.88(\mathrm{t}$, $3 \mathrm{H}, J=6.8 \mathrm{~Hz}) ;{ }^{13} \mathrm{C} \mathrm{NMR}\left(100 \mathrm{MHz}, \mathrm{CDCl}_{3}\right): \delta 138.5,128.4,127.7,127.6$, 74.4, 73.0, 70.3, 55.3, 31.9, 31.5, 29.8, 29.7, 29.7, 29.7, 29.7, 29.7, 29.6, 29.4, 29.0, 26.9, 26.2, 22.7, 14.1; IR (neat): 3310, 2926, $2854 \mathrm{~cm}^{-1}$.

\section{B.2.2 Reduction of 3 to $3^{\prime}$}

(3S,4S)-4-Amino-1-phenyl-hexan-3-ol (3a'):

${ }^{1} \mathrm{H}$ NMR (400 MHz, $\mathrm{CDCl}_{3}$ ): $\delta$ 7.31-7.16 (m, 5H), $3.31(\mathrm{ddd}, 1 \mathrm{H}, J=9.1,6.0$, $3.4 \mathrm{~Hz}$ ), 2.89 (ddd, $1 \mathrm{H}, J=13.7,10.2,5.3 \mathrm{~Hz}), 2.70(\mathrm{ddd}, 1 \mathrm{H}, J=13.7,10.0,6.6$ $\mathrm{Hz}), 2.52(\mathrm{~m}, 1 \mathrm{H}), 1.97$ (br s, 3H), $1.80(\mathrm{~m}, 1 \mathrm{H}), 1.71(\mathrm{~m}, 1 \mathrm{H}), 1.61(\mathrm{~m}, 1 \mathrm{H})$, $1.26(\mathrm{~m}, 1 \mathrm{H}), 0.94(\mathrm{t}, 3 \mathrm{H}, J=7.4 \mathrm{~Hz}) ;{ }^{13} \mathrm{C} \mathrm{NMR}\left(125 \mathrm{MHz}, \mathrm{CDCl}_{3}\right): \delta 142.4$, $128.5,128.4,125.8,72.7,57.3,36.4,32.3,27.0,10.5$; IR (neat): 3361, 2934, $2876 \mathrm{~cm}^{-1}$.

(2R,3S)-3-Amino-1-benzyloxy-pentan-2-ol (3b'):

${ }^{1} \mathrm{H}$ NMR $\left(400 \mathrm{MHz}, \mathrm{CDCl}_{3}\right): \delta 7.37-7.26(\mathrm{~m}, 5 \mathrm{H}), 4.56(\mathrm{AB}-\mathrm{q}, 2 \mathrm{H}, J=12.0 \mathrm{~Hz})$, $3.53(\mathrm{~m}, 3 \mathrm{H}), 2.73(\mathrm{~m}, 1 \mathrm{H}), 1.84$ (br s, 3H), $1.55(\mathrm{~m}, 1 \mathrm{H}), 1.29(\mathrm{~m}, 1 \mathrm{H}), 0.95(\mathrm{t}$, $3 \mathrm{H}, J=7.4 \mathrm{~Hz}) ;{ }^{13} \mathrm{C} \mathrm{NMR}\left(125 \mathrm{MHz}, \mathrm{CDCl}_{3}\right): \delta 138.1,128.4,127.7,127.7$, 73.5, 72.6, 72.2, 54.2, 27.3, 10.6; IR (neat): $3363,2932,2873 \mathrm{~cm}^{-1}$.

(2R,3R)-3-Amino-6-benzyloxy-hexan-2-ol (3d'):

${ }^{1} \mathrm{H}$ NMR (400 MHz, $\left.\mathrm{CDCl}_{3}\right): \delta$ 7.38-7.27 (m, 5H), $4.51(\mathrm{~s}, 2 \mathrm{H}), 3.50(\mathrm{t}, 2 \mathrm{H}, J=$ $6.3 \mathrm{~Hz}$ ), 3.41 (qui, 1H, J = 6.3 Hz), $2.44(\mathrm{~m}, 1 \mathrm{H}), 1.89$ (br s, 3H), $1.77(\mathrm{~m}, 1 \mathrm{H})$, $1.66(\mathrm{~m}, 2 \mathrm{H}), 1.26(\mathrm{~m}, 1 \mathrm{H}), 1.18(\mathrm{~d}, 3 \mathrm{H}, J=6.2 \mathrm{~Hz}) ;{ }^{13} \mathrm{C} \mathrm{NMR}(125 \mathrm{MHz}$, $\left.\mathrm{CDCl}_{3}\right): \delta 138.4,128.4,127.7,127.6,76.8,73.0,70.3,57.3,31.2,26.6,20.1$; IR (neat): $3362,2928,2857 \mathrm{~cm}^{-1}$. 
(2S,3R)-3-Amino-1-benzyloxy-octadecan-2-ol (3l'):

${ }^{1} \mathrm{H}$ NMR (400 MHz, $\mathrm{CDCl}_{3}$ ): $\delta$ 7.37-7.26 (m, 5H), 4.56 (AB-q, 2H, $J=12.0 \mathrm{~Hz}$ ), $3.58(\mathrm{dd}, 1 \mathrm{H}, J=7.3,5.1 \mathrm{~Hz}), 3.51(\mathrm{~m}, 2 \mathrm{H}), 2.80(\mathrm{~m}, 1 \mathrm{H}), 1.46(\mathrm{~m}, 2 \mathrm{H}), 1.26$ $(\mathrm{m}, 26 \mathrm{H}), 0.88(\mathrm{t}, 3 \mathrm{H}, J=6.8 \mathrm{~Hz}) ;{ }^{13} \mathrm{C} \mathrm{NMR}\left(100 \mathrm{MHz}, \mathrm{CDCl}_{3}\right): \delta 138.1,128.5$, 127.7, 127.7, 73.5, 72.7, 72.6, 52.6, 34.6, 32.0, 29.7, 29.7, 29.7, 29.7, 29.7, 29.7, 29.6, 29.6, 29.6, 29.4, 26.3, 22.7, 14.2; IR (neat): 3353, 2925, $2854 \mathrm{~cm}^{-1}$.

(4S,5S)-4-Amino-1-benzyloxy-octadecan-5-ol (3m'):

${ }^{1} \mathrm{H}$ NMR (400 MHz, $\left.\mathrm{CDCl}_{3}\right): \delta$ 7.37-7.27 (m, 5H), $4.51(\mathrm{~s}, 2 \mathrm{H}), 3.50(\mathrm{t}, 2 \mathrm{H}, J=$ $6.2 \mathrm{~Hz}), 3.25(\mathrm{~m}, 1 \mathrm{H}), 2.55(\mathrm{~m}, 1 \mathrm{H}), 1.75(\mathrm{~m}, 1 \mathrm{H}), 1.65(\mathrm{~m}, 1 \mathrm{H}), 1.48(\mathrm{~m}, 2 \mathrm{H})$, $1.26(\mathrm{~m}, 24 \mathrm{H}), 0.88(\mathrm{t}, 3 \mathrm{H}, J=6.8 \mathrm{~Hz}) ;{ }^{13} \mathrm{C} \mathrm{NMR}\left(125 \mathrm{MHz}, \mathrm{CDCl}_{3}\right): \delta 138.5$, 128.4, 127.7, 127.7, 73., 73.0, 70.3, 55.3, 34.4, 31.9, 31.3, 29.8, 29.7, 29.7, 29.7, 29.7, 29.7, 29.6, 29.4, 26.6, 25.9, 22.7, 14.1; IR (neat): 3363, 2932, $2857 \mathrm{~cm}^{-1}$.

\section{B.2.3 Reduction of 5 to $5^{\prime}$}

(3S,4R)-4-Amino-6-phenyl-hexan-3-ol (5a'):

${ }^{1} \mathrm{H}$ NMR (400 MHz, $\left.\mathrm{CDCl}_{3}\right): \delta 7.31-7.17(\mathrm{~m}, 5 \mathrm{H}), 3.39(\mathrm{dt}, 1 \mathrm{H}, J=8.8,3.9 \mathrm{~Hz})$, $2.81(\mathrm{~m}, 1 \mathrm{H}), 2.60(\mathrm{ddd}, 1 \mathrm{H}, J=13.8,9.6,6.8 \mathrm{~Hz}), 1.79(\mathrm{~m}, 1 \mathrm{H}), 1.70(\mathrm{br} \mathrm{s}, 3 \mathrm{H})$, $1.58(\mathrm{dtd}, 1 \mathrm{H}, J=13.8,9.6,5.4 \mathrm{~Hz}), 1.42(\mathrm{~m}, 2 \mathrm{H}), 0.97(\mathrm{t}, 3 \mathrm{H}, J=7.4 \mathrm{~Hz}) ;{ }^{13} \mathrm{C}$ NMR $\left(100 \mathrm{MHz}, \mathrm{CDCl}_{3}\right): \delta 141.9,128.4,128.3,125.9,76.0,54.6,33.9,32.9$, 24.4, 10.5; IR (neat): $3348,2963,2875 \mathrm{~cm}^{-1}$.

(2S,3S)-2-Amino-1-benzyloxy-pentan-3-ol (5b'):

${ }^{1} \mathrm{H}$ NMR (400 MHz, $\left.\mathrm{CDCl}_{3}\right): \delta$ 7.38-7.28 (m, 5H), $4.53(\mathrm{AB}-\mathrm{q}, 2 \mathrm{H}, J=11.9 \mathrm{~Hz})$, $3.59(\mathrm{dd}, 1 \mathrm{H}, J=9.3,4.1 \mathrm{~Hz}), 3.52(\mathrm{dd}, 1 \mathrm{H}, J=9.3,7.0 \mathrm{~Hz}), 3.47(\mathrm{dt}, 1 \mathrm{H}, J=$ 8.3, 4.3 Hz), 3.02 (dt, 1H, $J=7.0,4.3 \mathrm{~Hz}), 1.71$ (br s, 3H), $1.46(\mathrm{~m}, 2 \mathrm{H}), 0.99$ (t, $3 \mathrm{H}, J=7.4 \mathrm{~Hz}) ;{ }^{13} \mathrm{C} \mathrm{NMR}\left(125 \mathrm{MHz}, \mathrm{CDCl}_{3}\right): \delta 137.9,128.5,127.8,127.7$, 75.4, 73.5, 72.0, 54.1, 26.1, 10.4; IR (neat): 3364, 2937, $2874 \mathrm{~cm}^{-1}$.

(2S,3R)-2-Amino-6-benzyloxy-hexan-3-ol (5d'):

${ }^{1} \mathrm{H}$ NMR (400 MHz, $\mathrm{CDCl}_{3}$ ): $\delta$ 7.38-7.26 (m, 5H), $4.52(\mathrm{~s}, 2 \mathrm{H}), 3.53(\mathrm{t}, 2 \mathrm{H}, J=$ $6.2 \mathrm{~Hz}), 3.43(\mathrm{dt}, 1 \mathrm{H}, J=9.5,3.5 \mathrm{~Hz}), 2.96(\mathrm{~m}, 1 \mathrm{H}), 1.81(\mathrm{~m}, 1 \mathrm{H}), 1.77$ (br s, $3 \mathrm{H}), 1.72(\mathrm{~m}, 1 \mathrm{H}), 1.56(\mathrm{~m}, 1 \mathrm{H}), 1.43(\mathrm{~m}, 1 \mathrm{H}), 1.02(\mathrm{~d}, 3 \mathrm{H}, J=6.5 \mathrm{~Hz}) ;{ }^{13} \mathrm{C}$ NMR $\left(125 \mathrm{MHz}, \mathrm{CDCl}_{3}\right): \delta 138.3,128.4,127.7,127.6,74.8,73.0,70.5,50.6$, 29.5, 26.6, 17.4; IR (neat): 3354, 2940, $2864 \mathrm{~cm}^{-1}$.

(2S,3R)-2-Amino-1-benzyloxy-octadecan-3-ol (5l'):

${ }^{1} \mathrm{H}$ NMR (400 MHz, $\mathrm{CDCl}_{3}$ ): $\delta$ 7.38-7.26 (m, 5H), 4.53 (AB-q, 2H, $J=11.9 \mathrm{~Hz}$ ), $3.58(\mathrm{dd} 1 \mathrm{H}, J=9.3,4.2 \mathrm{~Hz}), 3.55(\mathrm{~m}, 1 \mathrm{H}), 3.52(\mathrm{dd} 1 \mathrm{H}, J=9.3,7.0 \mathrm{~Hz}), 3.00$ $(\mathrm{dt}, 1 \mathrm{H}, J=7.0,4.2 \mathrm{~Hz}), 1.85(\mathrm{~m}, 3 \mathrm{H}), 1.53-1.38(\mathrm{~m}, 4 \mathrm{H}), 1.26(\mathrm{~m}, 24 \mathrm{H}), 0.88(\mathrm{t}$, $3 \mathrm{H}, J=6.8 \mathrm{~Hz}) ;{ }^{13} \mathrm{C} \mathrm{NMR}\left(100 \mathrm{MHz}, \mathrm{CDCl}_{3}\right): \delta 137.9,128.5,127.8,127.8$, 73.9, 73.5, 71.9, 54.5, 33.3, 32.0, 29.7, 29.7, 29.7, 29.7, 29.7, 29.7, 29.6, 29.6, 29.6, 29.4, 26.1, 22.7, 14.2; IR (neat): $3352,2915,2848 \mathrm{~cm}^{-1}$. 
( \pm )-5-Amino-1-benzyloxy-octadecan-4-ol (5m'):

${ }^{1} \mathrm{H}$ NMR $\left(400 \mathrm{MHz}, \mathrm{CDCl}_{3}\right): \delta 7.36-7.26(\mathrm{~m}, 5 \mathrm{H}), 4.52(\mathrm{~s}, 2 \mathrm{H}), 3.53(\mathrm{t}, 2 \mathrm{H}, J=$ $6.1 \mathrm{~Hz}), 3.47(\mathrm{dt}, 1 \mathrm{H}, J=9.9,3.4 \mathrm{~Hz}), 2.76(\mathrm{~m}, 1 \mathrm{H}), 1.87-1.54(\mathrm{~m}, 5 \mathrm{H}), 1.42(\mathrm{~m}$, $2 \mathrm{H}), 1.26(\mathrm{~m}, 24 \mathrm{H}), 0.88(\mathrm{t}, 3 \mathrm{H}, J=6.8 \mathrm{~Hz}) ;{ }^{13} \mathrm{C} \mathrm{NMR}\left(100 \mathrm{MHz}, \mathrm{CDCl}_{3}\right)$ : $\delta 138.3,128.4,127.7,127.6,74.2,73.4,70.5,55.5,32.6,31.9,29.8,29.7,29.7$, 29.7, 29.7, 29.7, 29.6, 29.6, 29.4, 28.6, 26.6, 22.7, 14.1; IR (neat): 3354, 2924, $2854 \mathrm{~cm}^{-1}$.

\section{B.2.4 Reduction of 6 to $6^{\prime}$}

(3R,4R)-4-Amino-6-phenyl-hexan-3-ol (6a'):

${ }^{1} \mathrm{H}$ NMR (400 MHz, $\left.\mathrm{CDCl}_{3}\right): \delta$ 7.32-7.17 (m, 5H), $3.24(\mathrm{~m}, 1 \mathrm{H}), 2.79(\mathrm{ddd}, 1 \mathrm{H}, J$ $=13.9,10.0,5.5 \mathrm{~Hz}), 2.65(\mathrm{ddd}, 1 \mathrm{H}, J=13.9,9.7,6.6 \mathrm{~Hz}), 2.60(\mathrm{~m}, 1 \mathrm{H}), 1.89$ $(\mathrm{m}, 4 \mathrm{H}), 1.55(\mathrm{~m}, 2 \mathrm{H}), 1.40(\mathrm{~m}, 1 \mathrm{H}), 0.97(\mathrm{t}, 3 \mathrm{H}, J=7.4 \mathrm{~Hz}) ;{ }^{13} \mathrm{C}$ NMR $(125$ $\left.\mathrm{MHz}_{\mathrm{CDCl}}\right): \delta 141.8,128.5,128.3,126.0,75.1,54.6,36.3,32.7,27.1,10.1$; IR (neat): $3362,2935,2876 \mathrm{~cm}^{-1}$.

(2S,3R)-2-Amino-1-benzyloxy-pentan-3-ol (6b'):

${ }^{1} \mathrm{H}$ NMR (400 MHz, $\mathrm{CDCl}_{3}$ ): $\delta$ 7.38-7.26 (m, 5H), 4.54 (AB-q. $2 \mathrm{H}, J=11.9 \mathrm{~Hz}$ ), $3.58(\mathrm{dd}, 1 \mathrm{H}, J=9.3,4.0 \mathrm{~Hz}), 3.49(\mathrm{dd}, 1 \mathrm{H}, J=9.3,6.7 \mathrm{~Hz}), 3.42(\mathrm{ddd}, 1 \mathrm{H}, J=$ 9.6, 5.4, $4.3 \mathrm{~Hz}), 2.91(\mathrm{~m}, 1 \mathrm{H}), 1.89$ (br s, 3H), $1.48(\mathrm{~m}, 2 \mathrm{H}), 0.98$ (t, 3H, $J=7.4$ $\mathrm{Hz}) ;{ }^{13} \mathrm{C}$ NMR $\left(125 \mathrm{MHz}, \mathrm{CDCl}_{3}\right): \delta 137.9,128.5,127.8,127.7,73.6,73.5,73.2$, 54.1, 27.2, 10.2; IR (neat): 3370, 2934, $2874 \mathrm{~cm}^{-1}$.

(2S,3S)-2-Amino-6-benzyloxy-hexan-3-ol (6d'):

${ }^{1} \mathrm{H}$ NMR $\left(400 \mathrm{MHz}, \mathrm{CDCl}_{3}\right): \delta 7.37-7.26(\mathrm{~m}, 5 \mathrm{H}), 4.52(\mathrm{~s}, 2 \mathrm{H}), 3.53(\mathrm{td}, 1 \mathrm{H}, J=$ $6.2,2.6 \mathrm{~Hz}$ ), 3.19 (ddd $2 \mathrm{H}, J=9.3,6.3,3.1 \mathrm{~Hz}$ ), 2.73 (app. qui, $1 \mathrm{H}, J=6.4 \mathrm{~Hz}$ ), 1.88-1.62 (m, 3H), 1.55 (br s, 3H), $1.42(\mathrm{~m}, 1 \mathrm{H}), 1.09$ (d, 3H, $J=6.4 \mathrm{~Hz}),{ }^{13} \mathrm{C}$ NMR $\left(125 \mathrm{MHz}, \mathrm{CDCl}_{3}\right): \delta 138.4,128.4,127.7,127.6,75.6,73.0,70.5,51.2$, $31.2,26.2,21.0$; IR (neat): $3371,2944,2869 \mathrm{~cm}^{-1}$.

(2S,3S)-2-Amino-1-benzyloxy-octadecan-3-ol (6l'):

${ }^{1} \mathrm{H}$ NMR $\left(500 \mathrm{MHz}, \mathrm{CDCl}_{3}\right): \delta$ 7.37-7.27 (m, 5H), $4.52(\mathrm{AB}-\mathrm{q}, 2 \mathrm{H}, J=11.3 \mathrm{~Hz})$, $3.61(\mathrm{~m}, 1 \mathrm{H}), 3.55(\mathrm{~m}, 1 \mathrm{H}), 3.48(\mathrm{~m}, 1 \mathrm{H}), 2.86(\mathrm{dt}, 1 \mathrm{H}, J=6.4,4.1 \mathrm{~Hz}), 1.55(\mathrm{br}$ $\mathrm{s}, 3 \mathrm{H}), 1.42(\mathrm{~m}, 2 \mathrm{H}), 1.26(\mathrm{~m}, 26 \mathrm{H}), 0.88(\mathrm{t}, 3 \mathrm{H}, J=6.8 \mathrm{~Hz}) ;{ }^{13} \mathrm{C}$ NMR $(125$ $\left.\mathrm{MHz}, \mathrm{CDCl}_{3}\right): \delta 128.6,128.5,127.8,127.8,73.8,73.5,71.9,53.5,34.6,31.9$, 29.7, 29.7, 29.7, 29.7, 29.7, 29.7, 29.6, 29.6, 29.6, 29.4, 26.3, 22.7, 14.1.

(4S,5S)-5-Amino-1-benzyloxy-octadecan-4-ol (6m'):

${ }^{1} \mathrm{H}$ NMR $\left(500 \mathrm{MHz}, \mathrm{CDCl}_{3}\right): \delta$ 7.35-7.26 (m, 5H), $4.52(\mathrm{~s}, 2 \mathrm{H}), 3.52(\mathrm{~m}, 2 \mathrm{H})$, $3.26(\mathrm{ddd}, 1 \mathrm{H}, J=9.0,5.6,3.6 \mathrm{~Hz}), 2.53(\mathrm{~m}, 1 \mathrm{H}), 1.87-1.49(\mathrm{~m}, 5 \mathrm{H}), 1.43(\mathrm{~m}$, $2 \mathrm{H}), 1.27(\mathrm{~m}, 24 \mathrm{H}), 0.88(\mathrm{t}, 3 \mathrm{H}, J=6.8 \mathrm{~Hz}) ;{ }^{13} \mathrm{C} \mathrm{NMR}\left(125 \mathrm{MHz}, \mathrm{CDCl}_{3}\right)$ : $\delta 138.5,128.4,127.7,127.6,73.7,72.9,70.5,55.6,34.6,31.9,29.7,29.7,29.7$, $29.7,29.7,29.6,29.6,29.6,29.4,26.3,26.3,22.7,14.1$; IR (neat): 3332,2924 , $2853 \mathrm{~cm}^{-1}$. 
(2S,3S)-2-Propyl-3-vinyl-oxirane (1k):

${ }^{1} \mathrm{H}$ NMR (400 MHz, $\left.\mathrm{CDCl}_{3}\right): \delta 5.58(\mathrm{ddd}, 1 \mathrm{H}, J=17.2,9.9,7.3 \mathrm{~Hz}), 5.45(\mathrm{dd}$, $1 \mathrm{H}, J=17.2,1.6 \mathrm{~Hz}), 5.25(\mathrm{dd}, 1 \mathrm{H}, J=9.9,1.6 \mathrm{~Hz}), 3.09(\mathrm{dd}, 1 \mathrm{H}, J=7.2,2.2$ $\mathrm{Hz}), 2.83(\mathrm{dt}, 1 \mathrm{H}, J=5.9,2.2 \mathrm{~Hz}), 1.57-1.47(\mathrm{~m}, 4 \mathrm{H}), 0.96(\mathrm{t}, 3 \mathrm{H}, J=7.3 \mathrm{~Hz})$; ${ }^{13} \mathrm{C}$ NMR $\left(100 \mathrm{MHz}, \mathrm{CDCl}_{3}\right): \delta 135.8,118.7,60.3,58.7,34.1,19.3,14.1$.

(4R,5S)-5-Phenethyl-3-trityl-4-vinyl-[1,2,3]-oxathiazolidine 2,2-dioxide (16): ${ }^{1} \mathrm{H}$ NMR $\left(400 \mathrm{MHz}, \mathrm{CDCl}_{3}\right): \delta 7.58(\mathrm{~m}, 6 \mathrm{H}), 7.32-7.12(\mathrm{~m}, 12 \mathrm{H}), 7.04(\mathrm{~m}, 2 \mathrm{H})$, $5.72(\mathrm{~m}, 1 \mathrm{H}), 4.99(\mathrm{dd}, 1 \mathrm{H}, J=10.3,1.1 \mathrm{~Hz}), 4.93(\mathrm{dd}, 1 \mathrm{H}, J=16.9,1.1 \mathrm{~Hz})$, $3.57(\mathrm{dd}, 1 \mathrm{H}, J=7.3,1.1 \mathrm{~Hz}), 3.12(\mathrm{ddd}, 1 \mathrm{H}, J=7.3,4.8,2.2 \mathrm{~Hz}), 2.67(\mathrm{~m}, 1 \mathrm{H})$, $2.52(\mathrm{~m}, 1 \mathrm{H}), 1.81(\mathrm{~m}, 2 \mathrm{H})$.

(3S,4R)-4-(2,4-Dinitro-benzenesulfonyl)-amino-1-phenyl-hex-5-en-3-ol (17): ${ }^{1} \mathrm{H}$ NMR (500 MHz, $\left.\mathrm{CDCl}_{3}\right): \delta 8.66(\mathrm{~d}, 1 \mathrm{H}, J=2.2 \mathrm{~Hz}), 8.49(\mathrm{dd}, 1 \mathrm{H}, J=8.6$, $2.2 \mathrm{~Hz}), 8.25(\mathrm{~d}, 1 \mathrm{H}, J=8.6 \mathrm{~Hz}), 7.29(\mathrm{~m}, 2 \mathrm{H}), 7.22(\mathrm{t}, 1 \mathrm{H}, J=7.3 \mathrm{~Hz}), 7.16(\mathrm{~d}$, $1 \mathrm{H}, J=7.1 \mathrm{~Hz}), 6.07($ br s, $1 \mathrm{H}), 5.65(\mathrm{ddd}, 1 \mathrm{H}, J=17.4,10.3,7.8 \mathrm{~Hz}), 5.17(\mathrm{~d}$, $1 \mathrm{H}, J=17.4 \mathrm{~Hz}), 5.13(\mathrm{~d}, 1 \mathrm{H}, J=10.3 \mathrm{~Hz}), 4.06(\mathrm{dd}, 1 \mathrm{H}, J=7.8,3.3 \mathrm{~Hz}), 3.77$ (m, 1H), 2.79 (ddd, 1H, $J=14.2,8.7,6.1 \mathrm{~Hz}), 2.66(\mathrm{~m}, 1 \mathrm{H}), 1.96$ (br s, 1H), 1.80-1.68 (m, 2H); ${ }^{13} \mathrm{C}$ NMR (125 MHz, $\left.\mathrm{CDCl}_{3}\right): \delta 149.6,147.9,140.8,140.2$, $132.7,131.7,128.6,128.3,126.9,126.2,120.6,120.0,72.8,61.7,35.1,31.7$; IR (neat): $3359,2944,2878,1553,1353 \mathrm{~cm}^{-1}$.

(2R,3R)-1-(2,4-Dinitro-benzenesulfonyl)-2-phenethyl-3-vinyl-aziridine (18): ${ }^{1} \mathrm{H}$ NMR $\left(400 \mathrm{MHz}, \mathrm{CDCl}_{3}\right): \delta 8.55(\mathrm{~d}, 1 \mathrm{H}, J=2.2 \mathrm{~Hz}), 8.52(\mathrm{dd}, 1 \mathrm{H}, J=8.6$, $2.2 \mathrm{~Hz}), 8.38(\mathrm{~d}, 1 \mathrm{H}, J=8.6 \mathrm{~Hz}), 7.29-7.12(\mathrm{~m}, 5 \mathrm{H}), 5.75(\mathrm{ddd}, 1 \mathrm{H}, J=17.0$, $10.3,8.8 \mathrm{~Hz}), 5.43(\mathrm{~d}, 1 \mathrm{H}, J=17.0 \mathrm{~Hz}), 5.35(\mathrm{~d}, 1 \mathrm{H}, J=10.3 \mathrm{~Hz}), 3.23(\mathrm{dd}, 1 \mathrm{H}$, $J=8.8,4.7 \mathrm{~Hz}), 3.13(\mathrm{dt}, 1 \mathrm{H}, J=7.7,4.7 \mathrm{~Hz}), 2.84-2.67(\mathrm{~m}, 2 \mathrm{H}), 2.36(\mathrm{~m}, 1 \mathrm{H})$, $1.89(\mathrm{dq}, 1 \mathrm{H}, J=14.0,7.8 \mathrm{~Hz})$.

(3S,4R)-6-Phenyl- $N^{3}$-propyl-hex-1-ene-3,4-diamine (19):

${ }^{1} \mathrm{H}$ NMR $\left(500 \mathrm{MHz}, \mathrm{CDCl}_{3}\right): \delta 7.30(\mathrm{~m}, 2 \mathrm{H}), 7.22(\mathrm{~m}, 3 \mathrm{H}), 5.71(\mathrm{ddd}, 1 \mathrm{H}, J=$ 17.4, 10.5, 8.4 Hz), $2.87(\mathrm{~m}, 1 \mathrm{H}), 2.82(\mathrm{~m}, 1 \mathrm{H}), 2.69-2.58(\mathrm{~m}, 2 \mathrm{H}), 2.50(\mathrm{~m}, 1 \mathrm{H})$, $1.79(\mathrm{~m}, 3 \mathrm{H}), 1.62-1.44(\mathrm{~m}, 2 \mathrm{H}), 1.29(\mathrm{~m}, 2 \mathrm{H}), 0.94(\mathrm{t}, 3 \mathrm{H}, J=7.4 \mathrm{~Hz}) ;{ }^{13} \mathrm{C}$ NMR $\left(125 \mathrm{MHz}, \mathrm{CDCl}_{3}\right): \delta 142.2,136.5,128.4,128.4,125.8,118.3,66.2,53.6$, 49.2, 36.5, 32.9, 23.1, 11.8; IR (neat): 3297, 2932, $2872 \mathrm{~cm}^{-1}$.

(4S,5S)-5-(3-Benzyloxy-(E)-propenyl)-4-ethyl-2,5-dimethyl-4,5-

dihydrooxazole (21e): ${ }^{1} \mathrm{H}$ NMR $\left(400 \mathrm{MHz} \mathrm{CDCl}_{3}\right): \delta 7.37-7.25(\mathrm{~m}, 5 \mathrm{H}), 5.84$ $(\mathrm{m}, 2 \mathrm{H}), 4.53(\mathrm{~s}, 2 \mathrm{H}), 4.06(\mathrm{~d}, 2 \mathrm{H}, J=4.1 \mathrm{~Hz}), 3.67(\mathrm{t}, 1 \mathrm{H}, J=6.9 \mathrm{~Hz}), 2.03(\mathrm{~s}$, $3 \mathrm{H}), 1.53(\mathrm{~m}, 2 \mathrm{H}), 1.33(\mathrm{~s}, 3 \mathrm{H}), 1.07$ (t, 3H, $J=7.3 \mathrm{~Hz})$. 
(1R,2R)- $N$-(1-Vinyl-1,2,3,4-tetrahydro-naphthalen-2-yl)-acetamide (23):

White solid, mp 145-146 ${ }^{\circ} \mathrm{C} ;{ }^{1} \mathrm{H}$ NMR (400 MHz, $\mathrm{CDCl}_{3}$ ): $\delta$ 7.23-7.14 (m, 4H), 5.85 (ddd, $1 \mathrm{H}, J=17.1,10.1,8.1 \mathrm{~Hz}$ ), 5.46 (br s, $1 \mathrm{H}), 5.24$ (dt $1 \mathrm{H}, J=10.1 \mathrm{~Hz}$ ), $5.04(\mathrm{dt}, 2 \mathrm{H}, J=17.0,1.5 \mathrm{~Hz}), 4.19$ (ddd, $2 \mathrm{H}, J=16.2,8.2,3.0 \mathrm{~Hz}), 3.34$ (br t, $1 \mathrm{H}, J=7.5 \mathrm{~Hz}), 2.97(\mathrm{dt}, 1 \mathrm{H}, J=17.3,6.4 \mathrm{~Hz}), 2.86(\mathrm{dt}, 1 \mathrm{H}, J=17.3,6.2 \mathrm{~Hz})$, $1.99(\mathrm{~s}, 3 \mathrm{H}), 2.20(\mathrm{dtd}, 1 \mathrm{H} J=13.3,6.4,3.0 \mathrm{~Hz}), 1.79$ (ddt, $1 \mathrm{H} J=16.2,13.3$, $6.0 \mathrm{~Hz}) ;{ }^{13} \mathrm{C}$ NMR $\left(100 \mathrm{MHz}, \mathrm{CDCl}_{3}\right): \delta 169.6,140.0,135.6,135.2,130.1$, 129.0, 126.0, 126.0, 117.7, 50.2, 49.1, 26.6, 26.0, 23.6; IR (neat): 3305, 2939, 2850, $1645 \mathrm{~cm}^{-1}$; $\left[\alpha_{\mathbf{D}}\right.$ : $-58.0\left(c 0.23, \mathrm{CH}_{2} \mathrm{Cl}_{2}\right)$; HRMS (CI+): Exact mass calculated for $\mathrm{C}_{14} \mathrm{H}_{18} \mathrm{NO}(\mathrm{M}+\mathrm{H}): 216.1388$. Found: 216.1389 .

\section{$N$-[4-Benzyloxy-1(S)-(1(R)-hydroxy-propyl)-1-methyl-2-(E)-butenyl]-}

acetamide (24): ${ }^{1} \mathrm{H}$ NMR $\left(500 \mathrm{MHz}, \mathrm{CDCl}_{3}\right): \delta 7.37-7.27(\mathrm{~m}, 5 \mathrm{H}), 5.81(\mathrm{~d}, 1 \mathrm{H}$, $J=15.9 \mathrm{~Hz}), 5.70(\mathrm{dt}, 1 \mathrm{H}, J=15.9,5.5 \mathrm{~Hz}), 5.65(\mathrm{br} \mathrm{s}, 1 \mathrm{H}), 4.52(\mathrm{~s}, 2 \mathrm{H}), 4.31$ (br d, 1H, $J=9.1 \mathrm{~Hz}), 4.05$ (d, 2H, $J=5.5 \mathrm{~Hz}), 3.34(\mathrm{~m}, 1 \mathrm{H}), 2.00(\mathrm{~s}, 3 \mathrm{H}), 1.55$ (m, 2H), $1.47(\mathrm{~s}, 3 \mathrm{H}), 1.01(\mathrm{t}, 3 \mathrm{H}, J=7.4 \mathrm{~Hz}) ;{ }^{13} \mathrm{C}$ NMR $\left(125 \mathrm{MHz}, \mathrm{CDCl}_{3}\right): \delta$ $170.9,135.5,128.5,127.9,127.9,127.8,126.6,78.7,72.6,70.3,62.2,24.9,24.1$, 22.5, 11.2; IR (neat): $3307,2935,2875 \mathrm{~cm}^{-1}$.

(1S,2R)- $N$-(5-Benzyloxy-1-ethyl-2-hydroxy-2-methyl-3-(E)-pentenyl)acetamide (25): ${ }^{1} \mathrm{H}$ NMR $\left(500 \mathrm{MHz}, \mathrm{CDCl}_{3}\right): \delta 7.37-7.26(\mathrm{~m}, 5 \mathrm{H}), 5.87(\mathrm{dt}, 1 \mathrm{H}$, $J=15.6,5.5 \mathrm{~Hz}), 5.77(\mathrm{~d}, 1 \mathrm{H}, J=15.6 \mathrm{~Hz}), 5.48(\mathrm{br} d, 1 \mathrm{H}, J=9.8 \mathrm{~Hz}), 4.52(\mathrm{~s}$, $2 \mathrm{H}), 4.05$ (dd, $2 \mathrm{H}, J=5.5,1.2 \mathrm{~Hz}), 3.80(\mathrm{td}, 1 \mathrm{H}, J=9.8,2.8 \mathrm{~Hz}), 2.29$ (br s, $1 \mathrm{H})$, $2.04(\mathrm{~s}, 3 \mathrm{H}), 1.68(\mathrm{dq}, 2 \mathrm{H}, J=7.4,2.8 \mathrm{~Hz}), 1.29$ (s, 3H), 0.90 (t, 3H, $J=7.4 \mathrm{~Hz})$; ${ }^{13} \mathrm{CNMR}\left(125 \mathrm{MHz}, \mathrm{CDCl}_{3}\right): \delta 171.1,138.2,136.6,128.4,127.7,127.7,125.8$, 75.4, 72.4, 70.1, 58.7, 26.8, 23.3, 23.1, 11.1; IR (neat): 3314, 2932, 2872, 1650 $\mathrm{cm}^{-1}$.

(4S,5S)-3-Acetyl-5-(3-benzyloxy-(E)-propenyl)-4-ethyl-5-methyl-oxazolidin2-one (26): ${ }^{1} \mathrm{H}$ NMR $\left(400 \mathrm{MHz}, \mathrm{CDCl}_{3}\right): \delta 7.38-7.26(\mathrm{~m}, 5 \mathrm{H}), 5.91(\mathrm{dd}, 1 \mathrm{H}, J=$ $16.0,0.6 \mathrm{~Hz}), 5.82(\mathrm{dtd}, 1 \mathrm{H}, J=16.0,5.2,0.6 \mathrm{~Hz}), 4.51(\mathrm{~s}, 2 \mathrm{H}), 4.06(\mathrm{~d}, 2 \mathrm{H}, J=$ $5.1 \mathrm{~Hz}), 3.79(\mathrm{dd}, 1 \mathrm{H}, J=11.2,2.3 \mathrm{~Hz}), 2.04(\mathrm{~s}, 3 \mathrm{H}), 1.58(\mathrm{~s}, 3 \mathrm{H}), 1.39-1.21(\mathrm{~m}$, 2H), $1.02(\mathrm{t}, 3 \mathrm{H}, J=7.3 \mathrm{~Hz})$.

\section{2-Amino-1-benzyloxy-octadec-3-en-5-ol (40): \\ Major isomer: ${ }^{1} \mathrm{H}$ NMR $\left(400 \mathrm{MHz}, \mathrm{CDCl}_{3}\right): \delta$ 7.38-7.26 (m, 5H), $5.67(\mathrm{~m}, 2 \mathrm{H})$, $4.54(\mathrm{~s}, 2 \mathrm{H}), 4.08(\mathrm{dt}, 1 \mathrm{H}, J=6.7,6.1 \mathrm{~Hz}), 3.63(\mathrm{~m}, 1 \mathrm{H}), 3.49(\mathrm{~m}, 1 \mathrm{H}), 3.29(\mathrm{td}$, $1 \mathrm{H}, J=9.0,1.6 \mathrm{~Hz}), 1.57$ (br s, $3 \mathrm{H}), 1.351(\mathrm{~m}, 2 \mathrm{H}), 1.26(\mathrm{~m}, 22 \mathrm{H}), 0.88(\mathrm{t}, 3 \mathrm{H}, J$ $=6.8 \mathrm{~Hz}) ;{ }^{13} \mathrm{C}$ NMR $\left(125 \mathrm{MHz}, \mathrm{CDCl}_{3}\right): \delta 138.2,134.2,131.7,128.4,127.7$, 127.7, 75.3, 73.3, 72.6, 52.8, 37.4, 31.9, 29.7, 29.7, 29.7, 29.7, 29.6, 29.6, 29.6, 29.4, 25.4, 22.7, 14.1; IR (neat): 3422, 2919, $2848 \mathrm{~cm}^{-1}$.}

$N$-((1S,2R,3E)-1-Benzyloxymethyl-2-hydroxy-heptadec-3-enyl)-trifluoroacetamide (41): ${ }^{1} \mathrm{H}$ NMR (400 $\left.\mathrm{MHz} \mathrm{CDCl}_{3}\right): \delta 7.40-7.26(\mathrm{~m}, 5 \mathrm{H}), 7.01(\mathrm{br} \mathrm{d}$, $1 \mathrm{H}, J=8.5 \mathrm{~Hz}), 5.77(\mathrm{dtd}, 1 \mathrm{H}, J=15.4,6.9,1.2 \mathrm{~Hz}), 5.43(\mathrm{ddt}, 1 \mathrm{H}, J=15.4$, $6.3,1.2 \mathrm{~Hz}$ ), 4.51 (AB-q, 2H, $J=11.7 \mathrm{~Hz}), 4.23(\mathrm{~m}, 1 \mathrm{H}), 4.03$ (ddt, $1 \mathrm{H}, J=8.5$, 
5.1, $2.9 \mathrm{~Hz}), 3.89(\mathrm{dd}, 1 \mathrm{H}, J=9.9,2.9 \mathrm{~Hz}), 3.62(\mathrm{dd}, 1 \mathrm{H}, J=9.9,2.9 \mathrm{~Hz}), 2.69$ (br d, $1 \mathrm{H}, J=8.4 \mathrm{~Hz}), 2.02(\mathrm{q}, 2 \mathrm{H}, J=6.9 \mathrm{~Hz}), 1.32(\mathrm{~m}, 2 \mathrm{H}), 1.26(\mathrm{~m}, 22 \mathrm{H})$, $0.88(\mathrm{t}, 3 \mathrm{H}, J=6.8 \mathrm{~Hz}) ;{ }^{13} \mathrm{C}$ NMR $\left(125 \mathrm{MHz}, \mathrm{CDCl}_{3}\right): \delta$ 156.7, 136.9, 134.8, $128.7,128.3,128.2,127.9,127.9,73.8,73.3,68.5,53.1,32.2,31.9,29.7,29.7$, 29.7, 29.7, 29.6, 29.5, 29.4, 29.2, 29.0, 22.7, 14.1; IR (neat): 3294, 2919, 2851, $1699,1183 \mathrm{~cm}^{-1}$. 